\title{
Subsidence Above In Situ Vitrification: Evaluation for Hanford Applications
}

August 1995

Prepared by Golder Associates Inc.

for Pacific Northwest Laboratory under Contract DE-AC06-76RLO 1830 with the U.S. Department of Energy

Pacific Northwest Laboratory Operated for the U.S. Department of Energy by Battelle Memorial Institute 


\title{
DISCLAIMER
}

This report was prepared as an account of work sponsored by an agency of the United States Government. Neither the United States Government nor any agency thereof, nor Battelle Memorial Institute, nor any of their employees, makes any warranty, express or implied, or assumes any legal liability or responsibility for the accuracy, completeness, or usefulness of any information, apparatus, product, or process disclosed, or represents that its use would not infringe privately owned rights. Reference herein to any specific commercial product, process, or service by trade name, trademark, manufacturer, or otherwise does not necessarily constitute or imply its endorsement, recommendation, or favoring by the United States Government or any agency thereof, or Battelle Memorial institute. The views and opinions of authors expressed herein do not necessarily state or reflect those of the United States Government or any agency thereof.

\author{
PACIFIC NORTHWEST LABORATORY \\ operated by \\ BATTELLE MEMORIAL INSTITUTE \\ for the \\ UNITED STATES DEPARTMENT OF ENERGY \\ under Contract DE-ACO6-76RLO 1830
}

Printed in the United States of America

Available to DOE and DOE contractors from the

Office of Scientific and Technical Information, P.O. Box 62, Oak Ridge, TN 37831; prices available from $(615)$ 576-8401.

Available to the public from the National Techinical Information Service, U.S. Department of Commerce, 5285 Port Royal Rd., Springfield, VA 22161 


\section{DISCLAIMER}

Portions of this document may be illegible in electronic image products. Images are produced from the best available original document. 
This report was prepared as an account of work sponsored by an agency of the United States Government. Neither the United States Government nor any agency thereof, nor any of their employees, makes any warranty, express or implied, or assumes any legal liability or responsibility for the accuracy, completeness, or usefulness of any information, apparatus, product, or process disclosed, or represents that its use would not infringe privately owned rights. Reference herein to any specific commercial product, process, or service by trade name, trademark, manufacturer, or otherwise does not necessarily constitute or imply its endorsement, recommendation, or favoring by the United States Government or any agency thereof. The views and opinions of authors expressed herein do not necessarily state or reflect those of the United States Government or any agency thereof.

\section{Subsidence Above In Situ Vitrification: Evaluation for Hanford Applications}

W. S. Dershowitz, Golder Associates

R. L. Plum, Golder Associates

J. Luey, PNL Project Manager

August 1995

Prepared by Golder Associates Inc. for Pacific Northwest Laboratory under Contract DE-AC06-76RLO 1830 with the U.S. Department of Energy under Agreement 293407-A-B2

Pacific Northwest Laboratory Richland, Washington 



\section{Summary}

Pacific Northwest Laboratory (PNL) is evaluating methods to initiate the in situ vitrification (ISV) process in the soil subsurface. This extension of the ISV technology (which is traditionally started at the surface) has the potential to extend the ISV treatment depth beyond that currently demonstrated (approximately $6 \mathrm{~m}$ ) and allow for selective treatment of contamination in a geologic formation.

A potential issue associated with this extension of the technology is the degree of subsidence and its effect on the ISV process. The reduction in soil porosity caused by the vitrification process results in a volume decrease of the vitrified soils, which may create a void space above the vitrification zone. Movement of in-situ materials into this void space could result in surface settlements that affect the ISV process and/or processing equipment.

Golder Associates, Inc., (Redmond, Washington) evaluated the potential for subsidence events during application of ISV in the soil subsurface. Given the assumptions for material properties of the Hanford soil (both native and affected by the ISV process), the analysis and mechanisms considered lead to the following postulated scenarios:

- Surface settlements are not expected above an ISV melt radius of $5 \mathrm{ft}$ and an initiation depth of $15 \mathrm{ft}$.

- For melt radii of 10 to $15 \mathrm{ft}$, surface settlements of 5 to $10 \mathrm{in}$. are likely.

- Horizontal movement at the surface during subsidence is predicted to be minimal.

- Additional data for the properties of in-situ and fused materials are needed to increase the precision of the subsidence analysis.

Settlements greater than that predicted could occur for mechanisms not evaluated in this report. These additional mechanisms were not evaluated based on limited PNL experience indicating they were not credible. Further data is needed to determine if these additional mechanisms require analysis. The analysis was performed for application of ISV in the soil subsurface at Hanford or in Hanford-type soils. Further analysis is required before demonstration of the technology extension for other soil types. 



\section{Acknowledgments}

Pacific Northwest Laboratory (PNL) gratefully acknowledges the U.S. Department of Energy Office of Environmental Restoration, Richland Operations Office, for providing the funding to perform this subsidence analysis in support of the ISV Spot Melting project managed by PNL. Programmatic guidance for the project was provided by the Westinghouse Hanford Company and by Bechtel Hanford Incorporated. 


\section{Contents}

Summary $\ldots \ldots \ldots \ldots \ldots \ldots \ldots \ldots \ldots \ldots \ldots \ldots \ldots \ldots \ldots \ldots \ldots \ldots$ iii

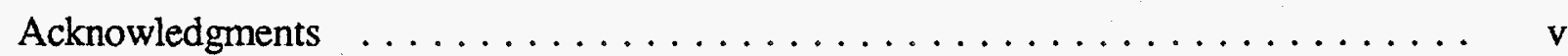

$1.0 \quad$ Introduction $\ldots \ldots \ldots \ldots \ldots \ldots \ldots \ldots \ldots \ldots \ldots \ldots \ldots \ldots \ldots \ldots \ldots$

2.0 Conclusions and Recommendations $\ldots \ldots \ldots \ldots \ldots \ldots \ldots \ldots \ldots \ldots \ldots \ldots \ldots$

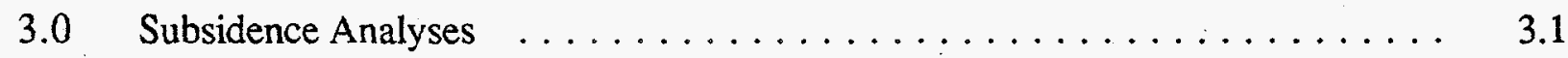

3.1 Assumptions And Material Properties $\ldots \ldots \ldots \ldots \ldots \ldots \ldots . . .6 .1$

3.1.1 Assumed Pilot-Scale Geometry $\ldots \ldots \ldots \ldots \ldots \ldots \ldots \ldots . .1$

3.1.2 Assumed Material Properties $\ldots \ldots \ldots \ldots \ldots \ldots \ldots .6 .1$

3.2 Subsidence Scenarios Evaluated $\ldots \ldots \ldots \ldots \ldots \ldots \ldots \ldots \ldots . \ldots \ldots$

3.2.1 Scenario 1: Structural Bridging of Void $\ldots \ldots \ldots \ldots \ldots .9 .9$

3.2.2 Scenario 2: Raveling and Bulking $\ldots \ldots \ldots \ldots \ldots \ldots \ldots \ldots$

3.3 Horizontal Movements . . . . . . . . . . . . . . . . . . 3.21

$4.0 \quad$ References $\ldots \ldots \ldots \ldots \ldots \ldots \ldots \ldots \ldots \ldots \ldots \ldots \ldots . . \ldots \ldots . . \ldots \ldots$

Appendix A - Failure of Fused Zone and Overlying Soils $\ldots \ldots \ldots \ldots \ldots \ldots$ A.1

Appendix B - Monte Carlo Simulations $\ldots \ldots \ldots \ldots \ldots \ldots \ldots \ldots \ldots$ B.1 


\section{Figures}

3.1 Schematic of Potential ISV Pilot-Scale Test Configuration $\ldots \ldots \ldots . \ldots . \ldots$

3.2 Particle Size Distribution for PNL's ISV Test Site Soils $\ldots \ldots \ldots \ldots$

3.3 Raveling and Bulking Schematic for ISV Subsidence Analysis (not to scale) ... 3.8

3.4 Schematic for Estimating Volume of Draw $\ldots \ldots \ldots \ldots . \ldots \ldots$

3.5 Average Subsidence for Range of Effective Bulking Factors and ISV Void Radii . $\quad 3.15$

3.6 Idealized Representation of Trough Subsidence $\ldots \ldots \ldots \ldots \ldots \ldots$

3.7 Subsidence at Trough Center $\ldots \ldots \ldots \ldots \ldots \ldots \ldots \ldots \ldots \ldots \ldots$

\section{Tables}

3.1 Soil Material Properties for ISV Subsidence Analysis $\ldots \ldots \ldots \ldots \ldots$

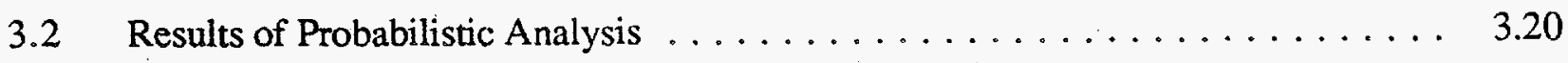




\subsection{Introduction}

Pacific Northwest Laboratory (PNL)(a) is evaluating methods to extend the applicability of the in situ vitrification (ISV) process. One method being evaluated is the initiation of the ISV process in the soil subsurface rather than the traditional start from the surface. The subsurface initiation approach will permit extension of the ISV treatment depth beyond that currently demonstrated (approximately $6 \mathrm{~m}$ ) and allow selective treatment of contamination in a geologic formation.

A potential issue associated with the initiation of the ISV process in the soil subsurface is the degree of subsidence and its effect on the ISV process. The reduction in soil porosity caused by the vitrification process will result in a volume decrease for the vitrified soils. Typical volume reduction observed for ISV melts initiated at the surface are on the order of $20 \%$ to $30 \%$ of the melt thickness (Luey, Roberts, and Timmerman 1993; Luey et al. 1992; Buelt et al. 1987). Movement of in-situ materials into the void space created during an ISV application in the soil subsurface could result in surface settlements that affect the ISV process and the processing equipment.

Golder Associates, Inc., (GAI) of Redmond, Washington investigated the potential for subsidence events during application of ISV in the soil subsurface. Prediction of soil subsidence above an ISV melt required the following analyses: the effect of porosity reduction during ISV, failure of fused materials surrounding the ISV melt, bulking of disturbed materials above the melt, and propagation of strains to the surface.

The subsidence analyses were performed using Hanford soil properties. Hanford soil was selected because the initial field demonstration of the new ISV application would likely be at PNL's test site (located west of the 300 Area on the Hanford Site). For the majority of the analyses, values for a pilot-scale system were used since that system is typically used for initial field demon- . strations. To determine the effect of scale on the analyses, multiple radii for the ISV melt were considered, as were different initiation depths for the ISV process.

(a) Pacific Northwest Laboratory is operated for the U.S. Department of Energy by Battelle Memorial Institute under Contract DE-AC06-76RLO 1830. 


\subsection{Conclusions And Recommendations}

An analysis was performed to evaluate the potential for subsidence events during application of a new ISV technique that initiates the process in the soil subsurface. Soil properties from the Hanford Site were selected for the evaluation since the first field demonstration of the new technique would likely occur at PNL's test site located on the Hanford Site. Results from the analysis provided the following conclusions:

- For the two scenarios evaluated, surface settlements are not expected for an ISV melt radius of $5 \mathrm{ft}$ (typical for the pilot-scale system) and an initiation depth of $15 \mathrm{ft}$. However, at larger melt radii of 10 to $15 \mathrm{ft}$ (typical of the full-scale system), surface settlements of 5 to $10 \mathrm{in}$. will likely occur.

- To increase the precision of the analysis for subsidence behavior, additional data are required to determine the properties of in-situ and fused materials. Field demonstration of the new ISV technique should consider soils tests (gradation testing, in-situ density measurements, and Maximum-Minimum Density tests) and should monitor subsurface deformations during subsidence and settlement (e.g., settlement markers, vertical extensometers, horizontal inclinometers).

- The relationship between the magnitude of maximum horizontal movement at the surface during subsidence and the maximum vertical subsidence indicates that horizontal movement should be minimal since vertical subsidence is minimal. However, to protect ISV equipment, the equipment should be designed so that the footings would be placed beyond the range of the predicted maximum horizontal movement.

Settlements greater than that predicted could occur for mechanisms not evaluated in this report. These additional mechanisms were not evaluated based on limited PNL experience indicating they were not credible. Further data is needed to determine if these additional mechanisms require analysis.

This report was prepared exclusively for PNL for specific application to a proposed ISV subsurface field test in sand and gravels at the Hanford site. The evaluation was performed in accordance with generally accepted geotechnical practices and analyses. It is recommended that contingencies be included in the planning of an ISV field test. Aspects related to subsidence should have a geotechnical review performed. Demonstration of the new ISV technique for other soil types will require further analysis. 


\subsection{Subsidence Analyses}

The reduction in porosity from ISV results in a volume decrease for the vitrified soils. Subsidence is visible when the process is initiated at the soil surface and has been observed, at engineering-scale, to create a void when started in the soil subsurface (Tixier, Stottlemyre, and Murphy 1991; Luey and Seiler 1995). At field-scale, movement of in-situ materials into the void space could cause surface settlements that adversely affect the ISV process and equipment. The magnitude and location of these settlements must be determined so that future ISV equipment can be adequately designed to preclude such event effects.

Figure 3.1 illustrates a potential pilot-scale geometry for initiating the ISV process in the soil subsurface. Initiation of the ISV process in the subsurface requires that ISV starter material be placed between an array of electrodes. The geometry shown in Figure 3.1 would be created using directional drilling techniques to create linear paths that connect diagonally opposed electrodes. A planar path between the electrodes is also a potential means for initiating the ISV process (Luey and Seiler 1994). Two subsidence scenarios have been identified for the geometry in Figure 3.1. This section evaluates the implications of these scenarios, including the effect of parameter uncertainties as well as uncertainties in the underlying mechanisms.

\subsection{Assumptions And Material Properties}

\subsubsection{Assumed Pilot-Scale Geometry}

The ISV melt was assumed to be approximately cylindrical in shape with the melt initiated at a depth of $15 \mathrm{ft}$ and progressing downward to a depth of $25 \mathrm{ft}$. A downward melt rate of approximately one inch per hour was used. The off-gas hood above the process area was assumed to be octagonal with a radius of $7 \mathrm{ft}$. In the calculations, a range of geometries for the ISV system was considered to determine differences between pilot-scale and larger scale systems. ISV melt radii of $5,10,15$, and $20 \mathrm{ft}$ were considered for initiation depths of 10,15 , and $25 \mathrm{ft}$. In all cases, the soil zone was $10 \mathrm{ft}$ thick.

\subsubsection{Assumed Material Properties}

Based on GAI observations, the primary geologic unit underlying PNL's test site is the Hanford formation. The Hanford formation soils are classified as GP (poorly graded gravels) according to ASTM D 2487 (1993), with $22 \%$ cobbles, $28 \%$ gravels, $20 \%$ medium to coarse sand, $25 \%$ fine sand, and $<5 \%$ fines (New Jersey Institute of Technology 1995). Figure 3.2 shows the results of a particle size distribution analysis performed by PNL specifically for this study; the results are consistent with those reported by New Jersey Institute of Technology (1995). The soil profile analyzed in this report considers the following (Figure 3.1):

- in-situ soils (sand and gravel) above the vitrification zone 


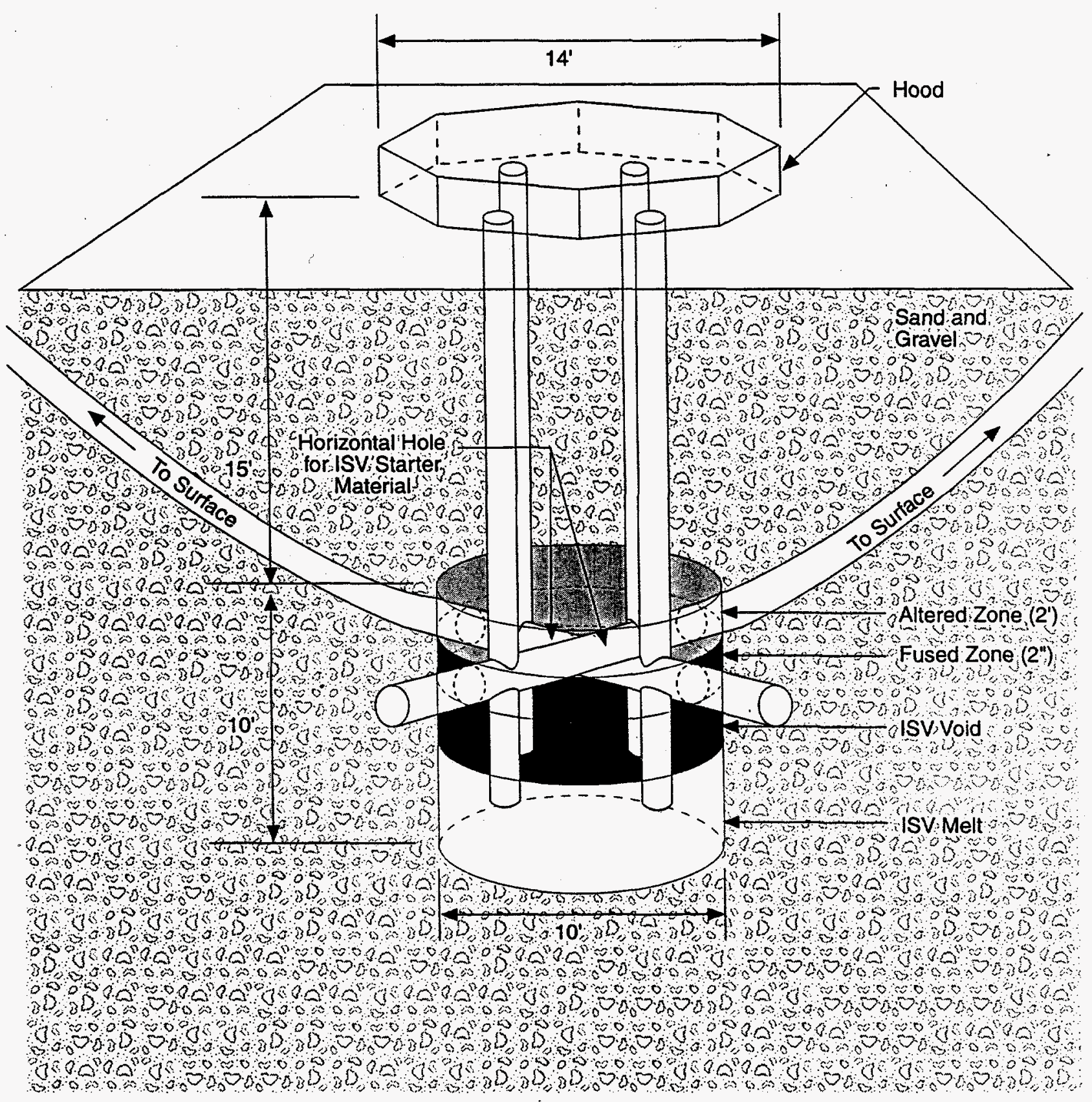

Figure 3.1. Schematic of Potential ISV Pilot-Scale Test Configuration 


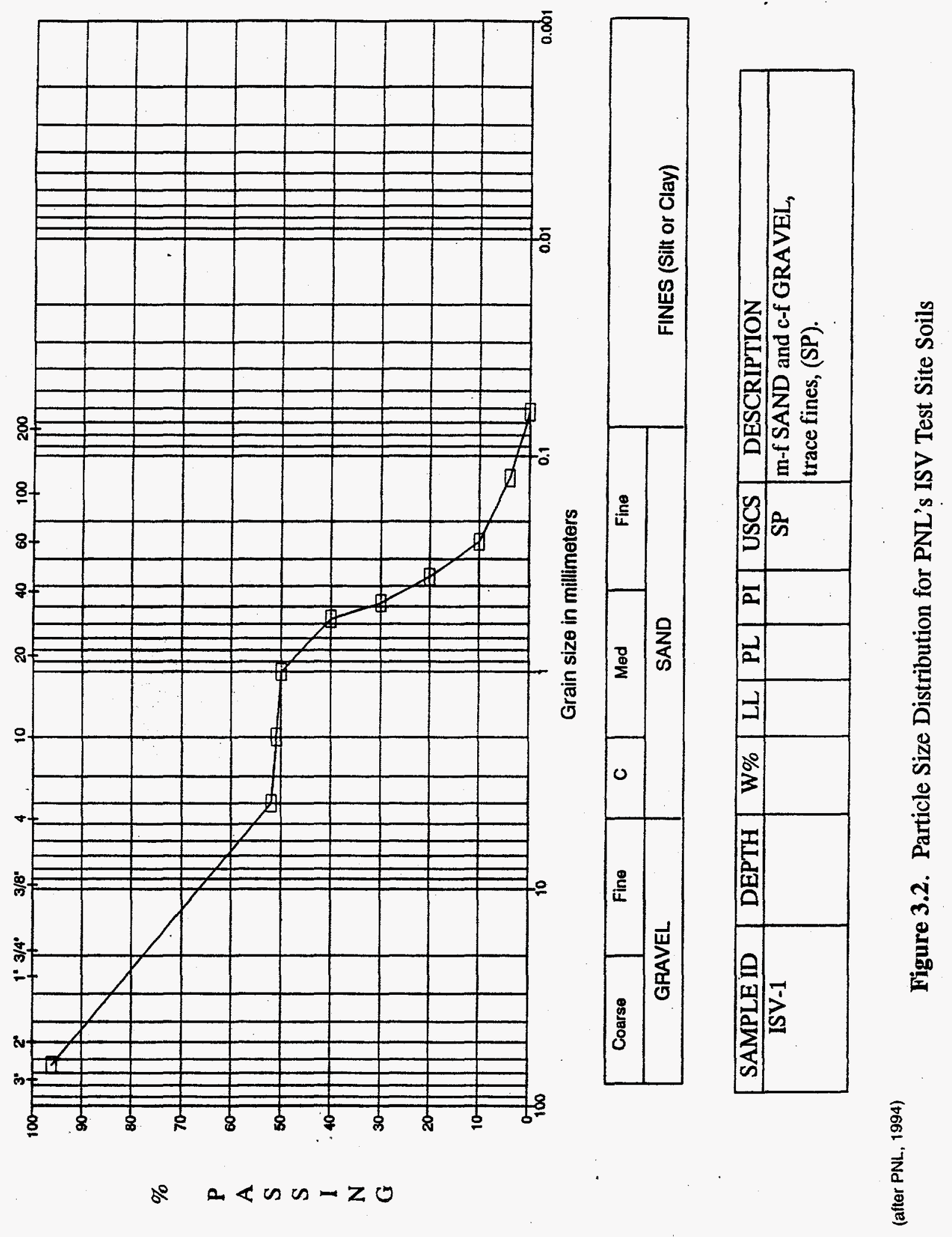


- in-situ soils in a thin zone, located approximately 2 in: to $2 \mathrm{ft}$ from the ISV melt, that may have been thermally altered slightly, resulting in a small increased cohesive strength

- fused in-situ soils immediately adjacent to the melt; in previous tests this zone has been about 2 in. thick and composed of fused sand and gravel fragments

- fused ISV melt itself.

Material properties for the soils at PNL's test site were based primarily on the grading curve shown in Figure 3.2 and on previous GAI experience with Hanford gravels. The range of material properties for these materials was derived based on GAI's previous Hanford experience and on a literature review (e.g., Pfleider 1972; Lambe and Whitman 1969; WPPSS 1974; Fang 1991; Clarke 1966; Vutukuri, Lama, and Saluja 1974; GAI 1981).

Although GAI has completed numerous projects at the Hanford Site, the most extensive geotechnical testing of Hanford gravels is summarized in work GAI performed in conjunction with several nuclear power siting studies during the 1980s (GAI 1981). The assumed material properties are summarized in Table 3.1 .

Table 3.1. Soil Material Properties for ISV Subsidence Analysis

\begin{tabular}{|c|c|c|c|c|}
\hline Property & Minimum & Most Likely & Maximum & Basis \\
\hline $\begin{array}{l}\text { Friction Angle, } \\
\text { In-Situ Soil }\end{array}$ & 36 & 38 & 40 & $\begin{array}{l}\text { GAI } 1981 \\
\text { Judgement }\end{array}$ \\
\hline $\begin{array}{l}\text { Cohesion, In-Situ } \\
\text { Soil (psf) }\end{array}$ & 0 & 25 & 100 & $\begin{array}{l}\text { GAI } 1981 \\
\text { Judgement }\end{array}$ \\
\hline $\begin{array}{l}\text { Maximum Dry } \\
\text { Density (pcf) }\end{array}$ & 130 & 135 & 140 & $\begin{array}{l}\text { GAI } 1981 \\
\text { Winkerton and Fang } 1975 \\
\text { Judgement }\end{array}$ \\
\hline $\begin{array}{l}\text { Minimum \% of } \\
\text { Maximum Dry } \\
\text { Density }\end{array}$ & 85 & 87.5 & 90 & $\begin{array}{l}\text { GAI } 1981 \\
\text { Winkerton and Fang } 1975 \\
\text { Judgement }\end{array}$ \\
\hline $\begin{array}{l}\text { In-Situ Relative } \\
\text { Density }(\%)\end{array}$ & 40 & 50 & 60 & $\begin{array}{l}\text { GAI } 1981 \\
\text { Judgement }\end{array}$ \\
\hline $\begin{array}{l}\text { Maximum Available } \\
\text { Bulking Factor, . } \\
\mathrm{B}_{\max }(\%)\end{array}$ & $@ N A$ & 6.7 & @NA & $\begin{array}{l}\text { Calculated from other } \\
\text { parameters }\end{array}$ \\
\hline $\begin{array}{l}\text { Tensile Strength, } \\
\text { Fused Soil, Obsidian } \\
\text { (psf) }\end{array}$ & 40,000 & 100,000 & 200,000 & $\begin{array}{l}\text { Vutukuri et al. } 1974 \\
\text { Clarke } 1966 \\
\text { Farmer } 1968\end{array}$ \\
\hline
\end{tabular}


Table 3.1. (contd)

\begin{tabular}{|c|c|c|c|c|}
\hline Property & Minimum & Most Likely & Maximum & Basis \\
\hline $\begin{array}{l}\text { Poisson's Ratio, } \\
\text { Fused Soil, } \\
\text { Obsidian }\end{array}$ & 0.25 & 0.25 & 0.3 & Clarke 1966 \\
\hline $\begin{array}{l}\text { Compressive } \\
\text { Strength, Fused } \\
\text { Soil, Obsidian (psf) }\end{array}$ & $5 \times 10^{5}$ & $2 \times 10^{6}$ & $1 \times 10^{7}$ & $\begin{array}{l}\text { Vutukuri et al. } 1974 \\
\text { Clarke } 1966 \\
\text { Farmer } 1968\end{array}$ \\
\hline $\begin{array}{l}\text { Compressive } \\
\text { Strength, Altered } \\
\text { In-Situ Soil (psf) }\end{array}$ & 5,000 & 7,500 & 15,000 & $\begin{array}{l}\text { Winkerton and Fang } 1975 \\
\text { (based on cohesion and } \\
\text { friction angle) }\end{array}$ \\
\hline $\begin{array}{l}\text { Average Porosity, } \\
\text { ISV Melt (\%) }\end{array}$ & 3 & 5 & 14 & Buelt et al. 1987 \\
\hline Angle of Draw $\left(^{\circ}\right)$ & 30 & 45 & 60 & $\begin{array}{l}\text { Golder and MacLaren } \\
1976\end{array}$ \\
\hline $\begin{array}{l}\text { Young's Modulus, } \\
\text { Fused Soil (psf) }\end{array}$ & $2 \times 10^{5}$ & $5 \times 10^{5}$ & $1 \times 10^{6}$ & Clarke 1966 \\
\hline $\begin{array}{l}\text { Young's Modulus, } \\
\text { Altered Soil (psf) }\end{array}$ & $1 \times 10^{8}$ & $5 \times 10^{8}$ & $1 \times 10^{9}$ & Clarke 1966 \\
\hline $\begin{array}{l}\text { Effective Bulking } \\
\text { Factor, Cp }(\%)\end{array}$ & 20 & 40 & 60 & Judgement \\
\hline $\begin{array}{l}\text { Effective Bulking, } \\
\text { Beff }(\%)\end{array}$ & @NA & 2.7 & $@ N A$ & $\begin{array}{l}\text { Calculated using } B_{\max } \\
\text { and } C_{p}\end{array}$ \\
\hline
\end{tabular}

Comments regarding several of these properties are included below:

- Friction Angle, In Situ Soil describes the shear strength of in-situ soils above the ISV melt and is used to estimate the resistance of these material to movement into the ISV melt and the void space created above the melt. The friction angle was estimated primarily on the basis of values reported for similar soils at the Hanford 300W Area (GAI 1981).

- Cohesion, In-Situ Soil describes the cohesive (stress independent) component of strength of in-situ soils above the ISV melt. These values were estimated based on values reported for similar soils at the Hanford 300W Area (GAI 1981) and on engineering judgment. 
- Relative Density, In-Situ Soil describes the unit weight of in-situ soils in terms o relative density compared to the Maximum and Minimum laboratory values. These values were estimated based on values reported for similar soils at the Hanford 300W Area (GAI 1981) and on engineering judgement.

- Tensile Strength, Fused Soil (Obsidian) describes the strength of the $\approx 2$-in.-thick zone of fused soils surrounding the ISV melt for failures in tension. The values are estimated primarily from values reported for boric anhydride glass (Clarke 1966). The ranges were estimated from values reported for similar materials by Farmer (1968) and Vutukuri, Lama, and Saluja (1974).

- Compressive Strength, Fused Soil (Obsidian) describes the strength of the approximately 2-in. thick zone of fused soils surrounding the ISV melt for failures in compression. The values are estimated primarily from values reported for obsidian (Vutukuri, Lama, and Saluja 1974). The ranges were estimated from values reported for similar materials by Farmer (1968) and Clarke (1966).

- Young's Modulus, Fused Soil describes the stress necessary to produce a unit strain. The values are estimated primarily from that reported for boric anhydride glass (Clarke 1966).

- Young's Modulus, Altered Soil describes the stress necessary for unit strain in thermally altered soils. These values were derived primarily from engineering judgment with reference to values for cemented soils.

- Compressive Strength, Altered Soil describes the increased compressive strength in the approximately 2 -ft-thick zone of altered soils surrounding the ISV melt. These values were derived from cohesion and friction angles from the literature, selected based on engineering judgement since actual data for similarly affect soils were unavailable.

- Average Porosity, ISV melt describes the void volume remaining in the fused soils following vitrification. Average porosity is used to estimate the volume of void space produced by the vitrification process. These values are estimated from the density values for the final ISV product reported by Buelt et al. (1987).

- Angle of Draw describes the angle of the cone of soils that are disturbed by the underground void formed during ISV. The angle of draw is defined as the angle between the horizontal and the cone of subsidence. This angle depends primarily on the geometry of the underground cavity, the depth of cover, and the friction angle of the in-situ materials. Values in the literature are reported primarily for tunnels rather than for cylindrical cavities. Golder and MacLaren (1976) present data on subsidence troughs above tunnels in cohesionless materials. The angles of draw for these near surface tunnels range from $23^{\circ}$ to $50^{\circ}$, with a mean of $38^{\circ}$. Brauner (1973) reports a range from $45^{\circ}$ to $65^{\circ}$ above mined caverns, with a few values as low as $35^{\circ}$. Thus, the angle of draw appears to be $10^{\circ}$ to $15^{\circ}$ higher for deep caverns when compared to shallow tunnels. The ISV condition is, in effect, a shallow tunnel cavern, so the angle of draw should lie between the shallow tunnel and deep cavern values. The angle of draw was therefore estimated as between $30^{\circ}$ and $60^{\circ}$ with a mean of $45^{\circ}$.

- Maximum Available Bulking Factor describes the maximum percent increase in volume that can be achieved when a material at its in-situ density is bulked to its minimum relative density. This factor was derived based on Maximum and Minimum density values reported for materials with similar grading curves (Fang 1991) combined with assumed in-situ relative density ranging from $40 \%$ to $60 \%$.

- Effective Bulking Factor is an empirical constant developed for this study to describe the average percentage of the maximum bulking factor that is achieved in raveling and disturbance of the soils above the ISV melt. This value depends on the degree of soil disturbance above the 
ISV melt, the nature of soil placement in the void created by the ISV process, and the percentage of raveling materials that fuse into the ISV melt (decreasing in volume). The value significantly affects the result of the analysis. However, because of a lack of data, this value was estimated based on engineering judgment. The value is multiplied by the Maximum Available Bulking Factor to calculate the average effective bulking factor in the zone of interest.

Porosity of the in-situ soil describes the percentage of void spaces in the in-situ soil as a percentage of soil volume. Values used in the analysis were calculated from the assumed in-situ densities using a Specific Gravity of 2.65 .

\subsection{Subsidence Scenarios Evaluated}

The possible subsidence behavior was modeled based on the following two related scenarios:

1. Structural Bridging Of Void: The ISV process produces void space at depth, which increases as the melt grows. Unless the overlying soil and thin fused soil zone have adequate strength, the roof of the developing void will collapse with the soil raveling into the void space. An evaluation was performed of this failure mechanism.

2. Raveling And Bulking: Assuming that the overlying soils have inadequate strength, the roof will collapse with the overlying soils raveling into the void as shown on Figure 3.3. The subsidence model consisted of the following assumed sequence:

- A portion of the collapsing soils may come into contact with high temperature melt materials. This may melt the raveling soils, which would join the fused mass and further increase the volume of the void. Based on the engineering judgement of PNL's ISV staff and observations made by Luey and Seiler (1995) during an engineering-scale test initiated in the subsurface, it is likely that only a small portion of the initially raveled soil would actually melt. This opinion is based on the fact that the active melt zone is moving downward at approximately one inch per hour, and the raveling soils will likely form a thermal barrier that will minimize upward growth of the melt.

- Once the thermal barrier forms, soils that break off and fall ("raveling") into the growing void decrease in density as they are transformed from the in-situ condition to their bulked or loosened condition.

- The decrease in soil density due to raveling cause a decrease in the void volume. Any void volume unaccounted for due to bulking would propagate to the surface, forming a subsidence trough with the shape of a normal distribution. 


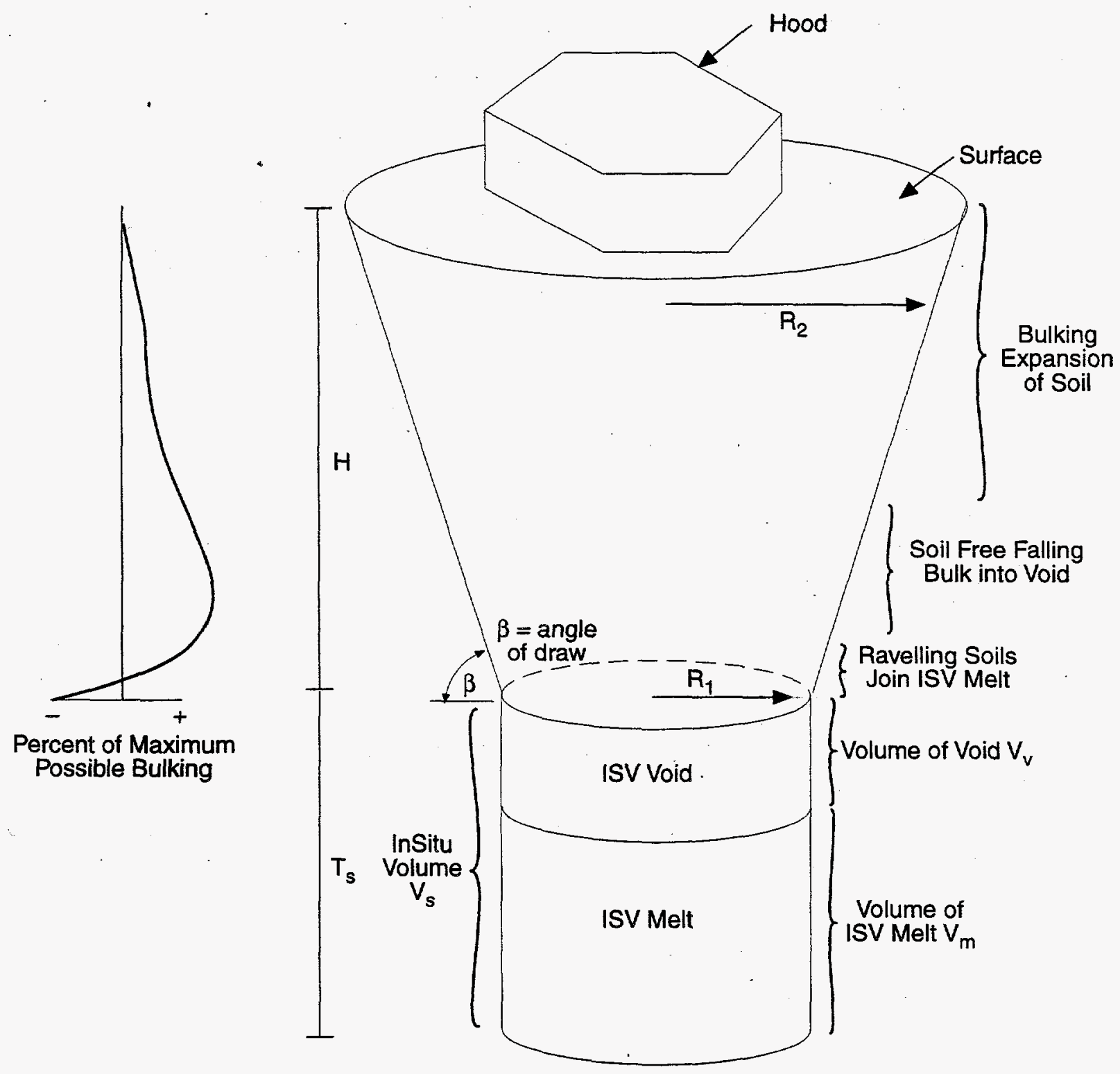

Schematic Not to Scale

Figure 3.3. Raveling and Bulking Schematic for ISV Subsidence Analysis (not to scale) 


\subsubsection{Scenario 1: Structural Bridging of Void}

\subsubsection{General Discussion}

Based on engineering judgment, it was considered unlikely that the overlying soil and thin fused soil zone would have adequate strength to bridge the void. Thus, rather then complete a sophisticated analysis, a cursory analysis based on several simplifying assumptions was made to assess the likelihood that bridging would occur. The approach consisted of two models:

- arching model to estimate stresses on the roof of the void

- structural analysis to compute the factor of safety of a failure occurring in the fused and altered zones. The main failure mode is tensile stress in the fused zone.

The analysis and results are summarized in the Appendix. In essence, the analysis indicated that the two-inch-thick fused zone is too thin to support the roof of the void except for very small melt radii less than about 1 to $2 \mathrm{ft}$. Such melt radii are similar to those for ISV engineering-scale tests. The presence of void spaces at completion of an engineering-scale test (Luey and Seiler 1995 ) is supported by this analysis. With a melt radius greater than $5 \mathrm{ft}$, effective bridging will not likely occur.

\subsubsection{Structural Lining Behavior}

The two-inch-thick fused zone is expected to completely surround the ISV melt. Theoretically, if the melt were spherical in shape, the fused zone would act as an outer structural "tunnel lining." This configuration would have considerable strength, since a structural liner would act as a ring in compression. The compressive stress on such a spherical liner could be calculated as (Obert and Duvall 1967),

$$
\sigma_{c}=\mathrm{K}_{\mathrm{r}} \gamma_{\mathrm{s}} \mathrm{HR}_{1} / \mathrm{t}_{\mathrm{f}}
$$

where $\mathrm{K}_{\mathrm{r}}$ is an empirical constant [approximately 0.6, Obert and Duvall (1967)] and $\mathrm{t}_{\mathrm{f}}$ is the effective fused zone thickness. The factor of safety, $\mathrm{F}_{\mathrm{s}}$, for failure of a structural liner in compression is then the ratio of the compressive strength, $S_{c}$, to the compressive stress,

$$
\mathrm{F}_{\mathrm{s}}=\mathrm{S}_{\mathrm{c}} / \sigma_{\mathrm{c}}
$$

The compressive strength of obsidian is approximately $2 \mathrm{M}$ psf (Vutukuri, Lama, and Saluja 1974). The results for a variety of assumptions imply that the 2 -in.-thick fused zone could fully support the overlying stresses and effectively eliminate any subsidence potential. 
However, this scenario is unlikely because the melt is not spherical and areas of tension forces will likely develop, resulting in the type of failure described in Section 3.2.1.1 above. In addition, as shown in Figure 3.1, the roof of the void is penetrated by the ISV electrode array, further weakening the fused zone above the ISV melt.

\subsubsection{Scenario 2: Raveling and Bulking}

\subsubsection{General Discussion}

Calculation of the subsidence due to the void space created by ISV is developed in this section. The calculation consists of determining the volume of the void, determining the volume of bulking available to fill the void, and propagation of this displacement to the surface. In addition to a conventional deterministic evaluation, a probabilistic evaluation was also completed.

\subsubsection{Estimate of the Volume of the ISV Void}

The void created by the ISV process would be equal to the in situ volume of the soils before vitrification, $\mathrm{V}_{\mathrm{s}}$, multiplied by the difference between the in-situ porosity, $\mathrm{n}_{0}$, and the porosity following vitrification, $n_{v}$,

$$
\begin{gathered}
V_{s}=V_{v}+V_{m} \\
V_{v}=V_{s}\left(n_{0}-n_{v}\right) /\left(1-n_{v}\right)
\end{gathered}
$$

where $V_{v}$ is the volume of the void space created by the ISV process and $V_{m}$ is the volume of vitrified material. For a cylindrical soil volume of height $T_{s}$, the relationship between the volume of the void and the radius, $R_{1}$, of the ISV soil volume is:

$$
\begin{gathered}
V_{s}=\pi R_{1}^{2} T_{s} \\
V_{v}=\pi R_{1}^{2} T_{s}\left(n_{0}-n_{v}\right) /\left(1-n_{v}\right)
\end{gathered}
$$

The average height of the void, $D_{v}$, can be calculated by dividing the volume of the void by the area, $A_{v}$, as follows:

$$
\begin{gathered}
D_{v}=V_{v} / A_{v} \\
D_{v}=V_{v} /\left(\pi R_{1}^{2}\right) . \\
D_{v}=T_{s}\left(n_{0}-n_{v}\right) /\left(1-n_{v}\right)
\end{gathered}
$$


Given a soil volume height, $\mathrm{T}_{\mathrm{s}}$, of $10 \mathrm{ft}$, an assumed in-situ porosity of $22 \%$, and an ISV melt porosity of $5 \%$ based on most likely values in Table 3.1 , the average void height, $D_{v}$, is about $2 \mathrm{ft}$. This value provides a practical upper bound estimate on average settlement, although a somewhat higher upper bound could be obtained considering melting of raveled materials from above the ISV void.

\subsubsection{Bulking Analysis - Maximum Available Bulking}

After calculation of the volume of the ISV void, the next calculation required is the volume increase in the materials above the ISV void. Bulking is well documented in tunneling (Golder and MacLaren 1976), underground mining (Pfleider 1972), and subsidence prediction (NCB 1975). The magnitude of bulking depends on the relative density of the in-situ materials and the nature of their in-situ and disturbed structures.

A range of maximum and minimum densities for soils are reported in Fang (1991). Of the 56 soils reported by Fang, six were selected as the most similar to the gradation curve for the PNL test site soils. The average maximum-minimum densities for the six soils selected was about $137 \mathrm{pcf}$ (maximum) and $115 \mathrm{pcf}$ (minimum). A Maximum-Minimum Density test was completed for another GAI project at the Hanford Site on the Hanford gravels indicated a maximum density of 135 pcf and a minimum density of 120 pcf.

The maximum available bulking percentage, $B_{\max }$, depends on the in-situ density, $\gamma_{0}$, and the minimum density, $\gamma_{\min }$. The maximum available bulking percentage can be calculated as follows:

$$
\mathrm{B}_{\max }=\frac{\gamma_{0}-\gamma_{\min }}{\gamma_{\min }}
$$

Using the most likely values shown in Table 3.1 , the computed $\mathrm{B}_{\max }$ value was $6.7 \%$.

\subsubsection{Bulking Analysis - Average Effective Bulking}

The actual bulking behavior is likely to be relatively complex as the melt grows and soil ravels or bulks into the void. The initial raveled soil may melt and be incorporated into the melt, producing in effect a negative bulking factor. Soil that initially ravels into the void and does not melt may bulk to the minimum density. As the melt continues and a zone of loosened soil develops above the melt, there will likely be a transition from soil at a minimum density at the top of the melt to soil at the in-situ density at the top of the bulked zone. The effective bulking is defined as the average bulking factor in the disturbed zone affected by the melt. Theoretically, the effective bulking can be obtained by integrating the change in density within the disturbed zone from the in-situ density, $\gamma_{0}(z)$, to the disturbed in-situ density, $\gamma_{B}(z)$ : 


$$
B_{\text {eff }}=B_{\max } \underset{z=\text { void }}{\mid} \frac{\gamma_{0}(z)-\gamma_{B}(z)}{\gamma_{0}(z)} d z
$$

There is no information on the likely distribution of density following disturbance. In addition, the likelihood and extent of raveling soils fusing into the melt and increasing in density is unknown. In order to account for these effects, the analysis related effective bulking to the maximum available bulking by an empirical proportionality constant, $\mathrm{C}_{\mathrm{b}}$,

$$
B_{\text {eff }}=C_{b} B_{\max }
$$

$C_{b}$ is referred to as the "effective bulking factor." A value of $C_{b}$ of 1.0 would result if all soils within the disturbed zone bulked from the in-situ density to the minimum density. A value of $\mathrm{C}_{b}$ of 0 would result if the average density of the disturbed soils was the same after disturbance as before disturbance, as a result of the compensating effects of bulking and density increase due to fusing in the zone near the melt.

The volume of bulking, $V_{b}$, can be calculated as the volume of disturbed materials, $V_{d}$, multiplied by the effective bulking $B_{\text {eff. }}$ The volume of disturbed materials is generally estimated using the "angle of draw" B (Brauner 1973). The angle of draw is the angle of the cone of disturbed materials and is generally significantly shallower than the "angle of break," $\alpha$, along which shear resistance is mobilized.

The volume of the disturbed materials can be estimated from the angle of draw B as shown in Figure 3.4. $R_{2}$ is the radius of the subsiding area at the surface.

$$
\begin{gathered}
V_{b}=B_{\text {eff }} V_{d} \\
V_{b}=\frac{B_{\max } C_{b} H \pi}{3}\left(R_{1}^{2}+R_{2}^{2}+R_{1} R_{2}\right) \\
R_{2}=\tan (90-B)\left(H+\frac{R_{1}}{\tan (90-B)}\right)
\end{gathered}
$$

The volume of the subsidence trough Vs can be estimated from the volume of the underground void minus the bulking volume, assuming that the bulking completely fills the void.

$$
V_{s}=V_{v}-V_{b}
$$


a. Volume of Disturbed Zone

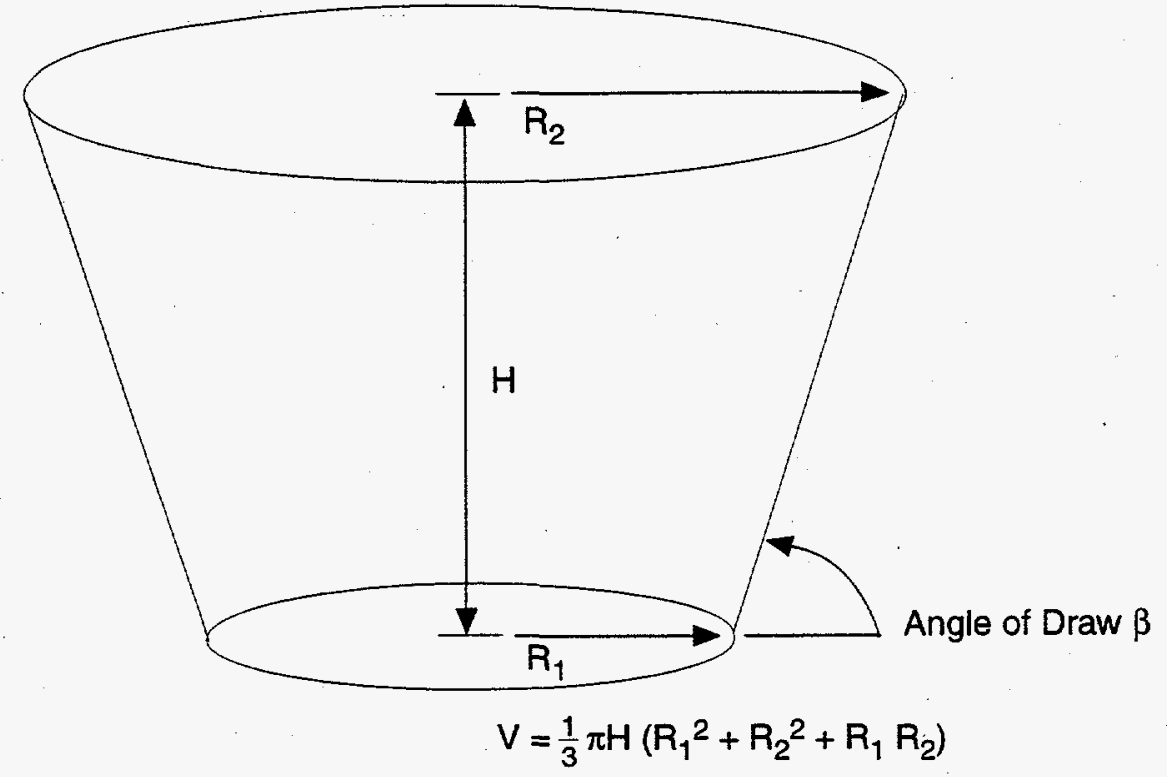

b. Volume of Settlement through Surface Subsidence Radius $R_{2}$

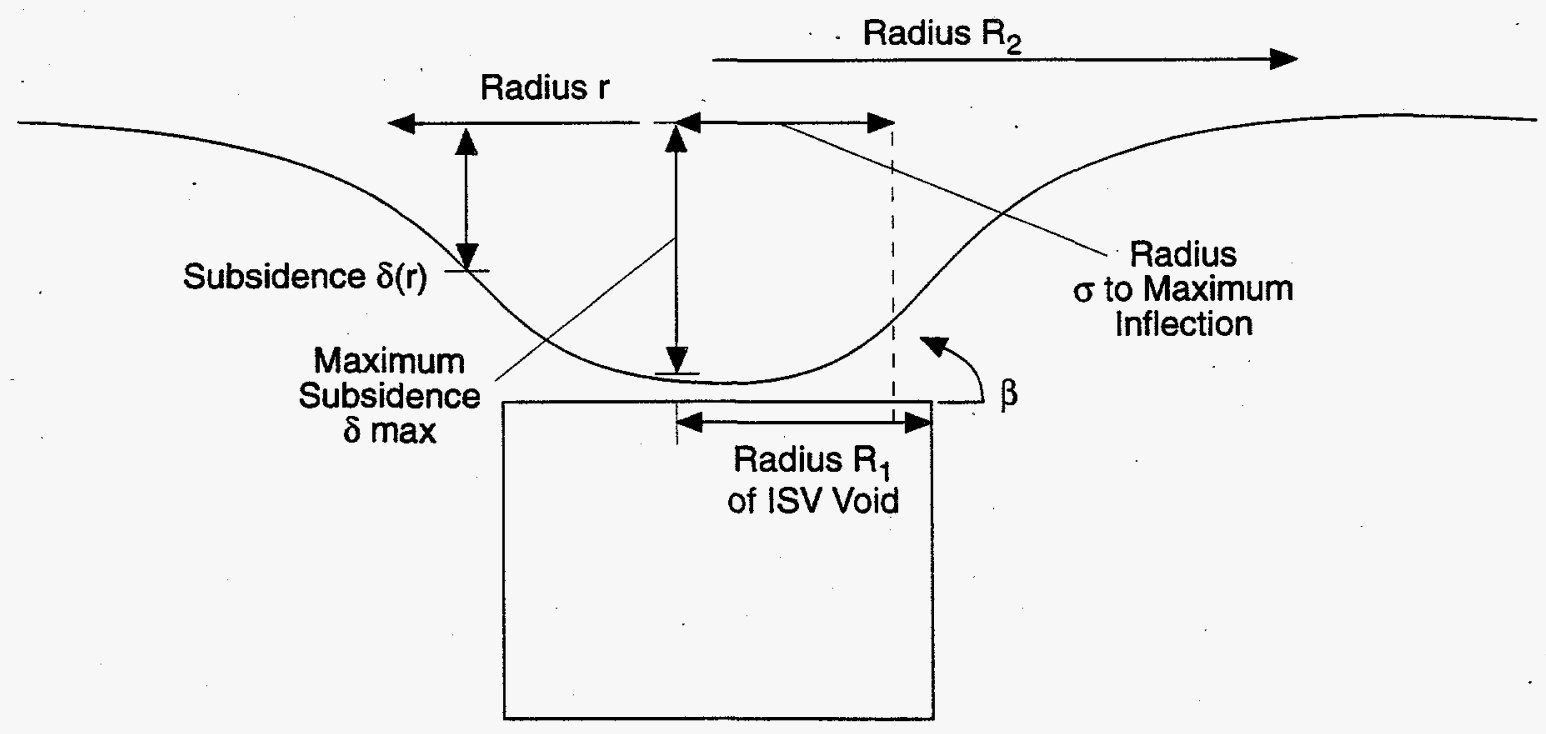

Figure 3.4. Schematic for Estimating Volume of Draw 
The volume of the ISV void was estimated assuming a cylindrical melt. Figure 3.5 shows the average subsidence for a range of effective bulking factors, Beff, assuming a decrease in porosity for the ISV melt of about $17 \%$ based on the most likely values shown in Table 3.1. For most values of angle of draw and effective bulking factors, the average subsidence and total volume of subsidence would be zero. For a typical combination $\left(R_{1}=5^{\prime}, \mathrm{H}=15^{\prime}, \mathrm{B}=45^{\circ}\right)$, an effective bulking factor of less than $2 \%$ would be sufficient to prevent the appearance of settlement at the surface.

\subsubsection{Maximum Subsidence}

The average value of subsidence, $\delta_{\mathrm{av}}$, can be calculated by dividing the volume of subsidence by the area over which subsidence occurs,

$$
\delta_{\mathrm{av}}=\frac{\mathrm{Vs}}{\pi \mathrm{R}_{2}^{2}}
$$

However, it is more useful to calculate the maximum subsidence (i.e., at the center) and the subsidence at the edge of the ISV off-gas hood.

The shape of the surface settlement troughs is well established to usually take the form of a normal distribution (see Obert and Duvall 1967; Pfleider 1972; Brauner 1973). The maximum subsidence can therefore be calculated from the volume of the subsidence trough and the angle of draw (Figure 3.4b). A normally shaped subsidence trough is shown in Figure 3.6 and is defined by

$$
\delta(r)=\delta_{\max } e^{-r^{2} /\left(2 \sigma^{2}\right)}
$$

where $\sigma$ is the distance from the point of maximum subsidence to the point of inflection in the subsidence profile (Golder and MacLaren 1976). The radial distance sigma can be estimated from a relationship from Obert and Duvall (1967)

$$
\sigma \approx \frac{\mathrm{R}_{2}}{2}
$$




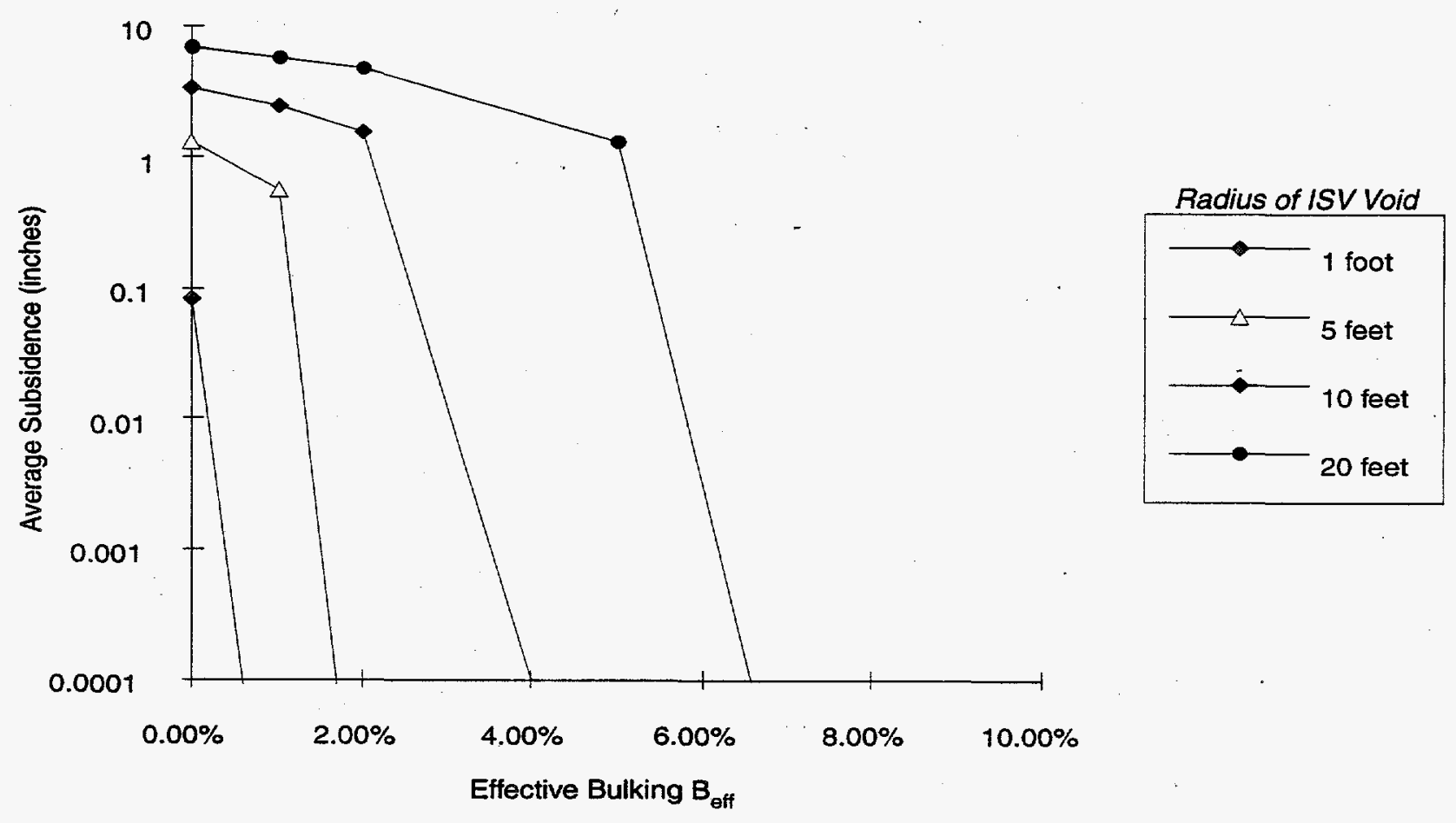

Assumptions

In Situ Porosity $22 \%$

ISV Melt Porosity $5 \%$

Depth 15'

Angle of Draw $45^{\circ}$

Average subsidence calculated as

trough volume divided by trough

area (radius $=R_{2}$, see text)

Figure 3.5. Average Subsidence for Range of Effective Bulking Factors and ISV Void Radii 


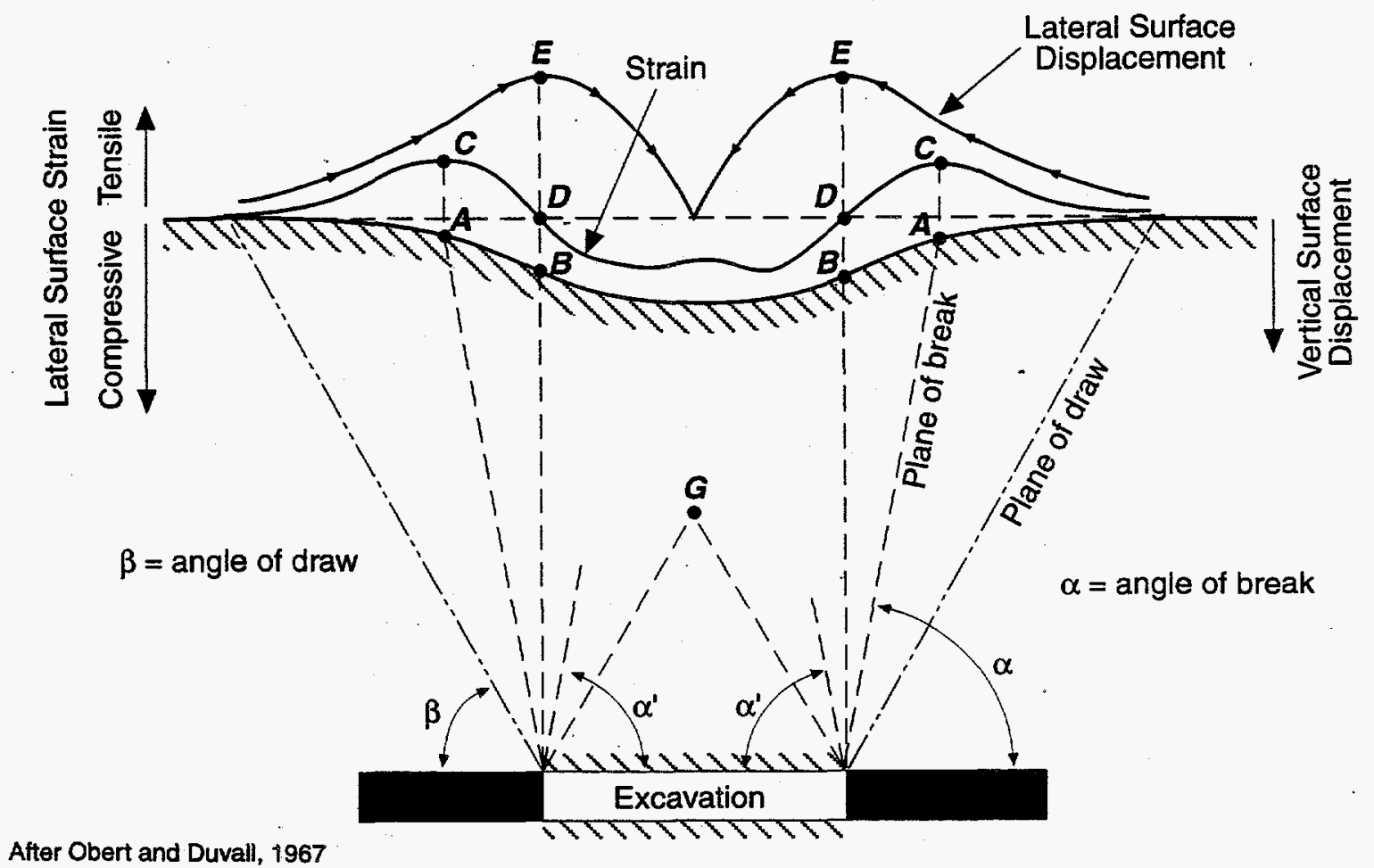

Figure 3.6. Idealized Representation of Trough Subsidence (after Obert and Duvall 1987)

The maximum subsidence, $\delta_{\max }$, can be found by integrating the area under the subsidence curve to the total subsidence, $V_{s}$

$$
\begin{gathered}
V s=I_{0}^{2 \pi \infty} I_{0}^{\infty} \delta(x) d r d \theta \\
V_{s}=\left.2 \pi \delta_{\max }^{\infty}\right|_{0} ^{\infty} e^{-r^{2} /\left(2 \sigma^{2}\right)} d r \\
\delta_{\max }=\frac{V_{s}}{\left.2 \pi\right|_{0} ^{\infty} e^{-r^{2} /\left(2 \sigma^{2}\right)} d r}=\frac{V_{s}}{2 \pi \sigma^{2}}
\end{gathered}
$$


Figure 3.7 shows the maximum settlement, $\delta_{\max }$, for a range of initial in-situ porosities, angles of draw, and effective bulking factors. The porosity of the ISV melt is assumed to be 5\%. The settlement $\delta(r)$ at any point at the surface can then be calculated using equation 12 . Given an angle of draw of $45^{\circ}$, an effective bulking factor of $2.7 \%$, an initial in-situ porosity of $22 \%$, a melt radius of $5 \mathrm{ft}$, and a melt depth of $15 \mathrm{ft}$, the maximum subsidence is calculated to be zero. These are considered the most likely values. It was necessary to use either a very low effective bulking factor or an unrealistically high angle of draw to produce any surface subsidence at a melt radius of $5 \mathrm{ft}$. At a radius of $10 \mathrm{ft}$, the most likely values indicated a surface subsidence of about $2.5 \mathrm{in}$.

\subsubsection{Probabilistic Analysis}

In order to obtain a probabilistic estimate of subsidence, a range of material properties were simulated using the Monte Carlo method within an Excel 4.0/Crystal Ball 3.0 model. Appendix B presents the results for a number of Monte Carlo model simulation runs. This model made the following assumptions:

- The dominate mechanism is bulking with limited meting of the initial raveling soil; the probabilistic analysis does not consider the case of significant melting of the ravelled soils, which would result in much larger settlement values.

- The material properties were described by triangular distributions of properties, using the values in Table 3.1. The properties simulated using stochastic properties were angle of draw, maximum available bulking $\left(B_{\max }\right)$, effective bulking factor $\left(C_{b}\right)$, in-situ soil porosity, and the average porosity of the ISV melt.

- The settlement trough volume is calculated as the volume of the ISV void less the volume of bulking, as described in Section 3.2.2.4.

- The shape of the settlement trough is normal as described in Section 3.2.2.5.

Because of the likely volume of bulking, the probability of subsidence was low for an ISV pilot-scale application with a melt radius of $5 \mathrm{ft}$ and an initiation depth of $15 \mathrm{ft}$. However, for a melt radius of 10 or $15 \mathrm{ft}$ (typical dimensions for a full-scale ISV melt), the likelihood of subsidence increases significantly. Table 3.2 summarizes the results of several geometries and probability values. At a depth of $15 \mathrm{ft}$, the expected maximum settlement (50th percentile value) for a melt radius of $5 \mathrm{ft}$ was zero. For the 95 th percentile value, the maximum subsidence was about $0.75 \mathrm{in}$. At a melt radius of $10 \mathrm{ft}$, the results increased to about $1.8 \mathrm{in}$. (50th percentile) and $6 \mathrm{in}$. (95th percentile). At a melt radius of $15 \mathrm{ft}$, the results increased to about $5 \mathrm{in}$. (50th percentile) and 10 in. (95th percentile). 
a. Maximum Subsidence, ISV Melt Radius $=5$ feet

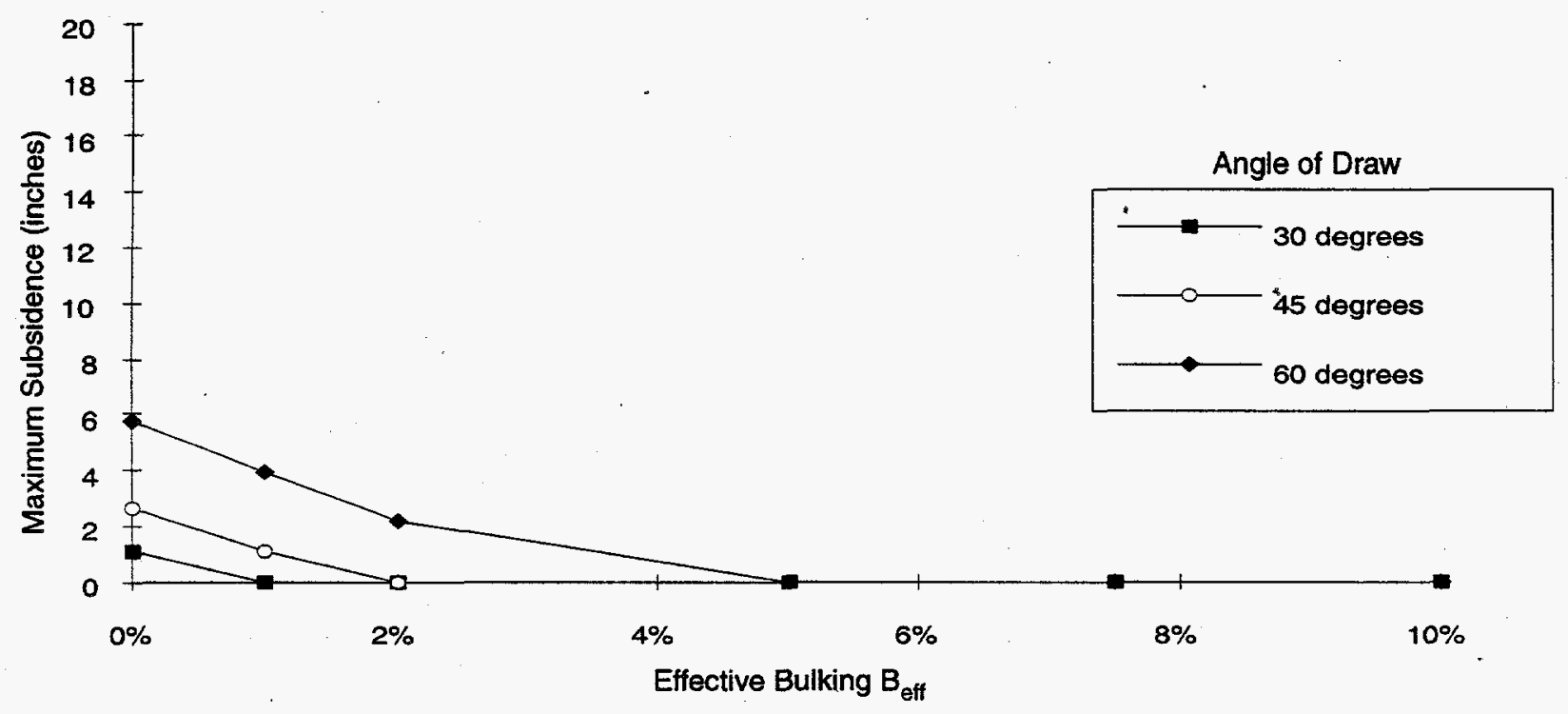

b. Maximum Subsidence, ISV Melt Radius $=10$ feet

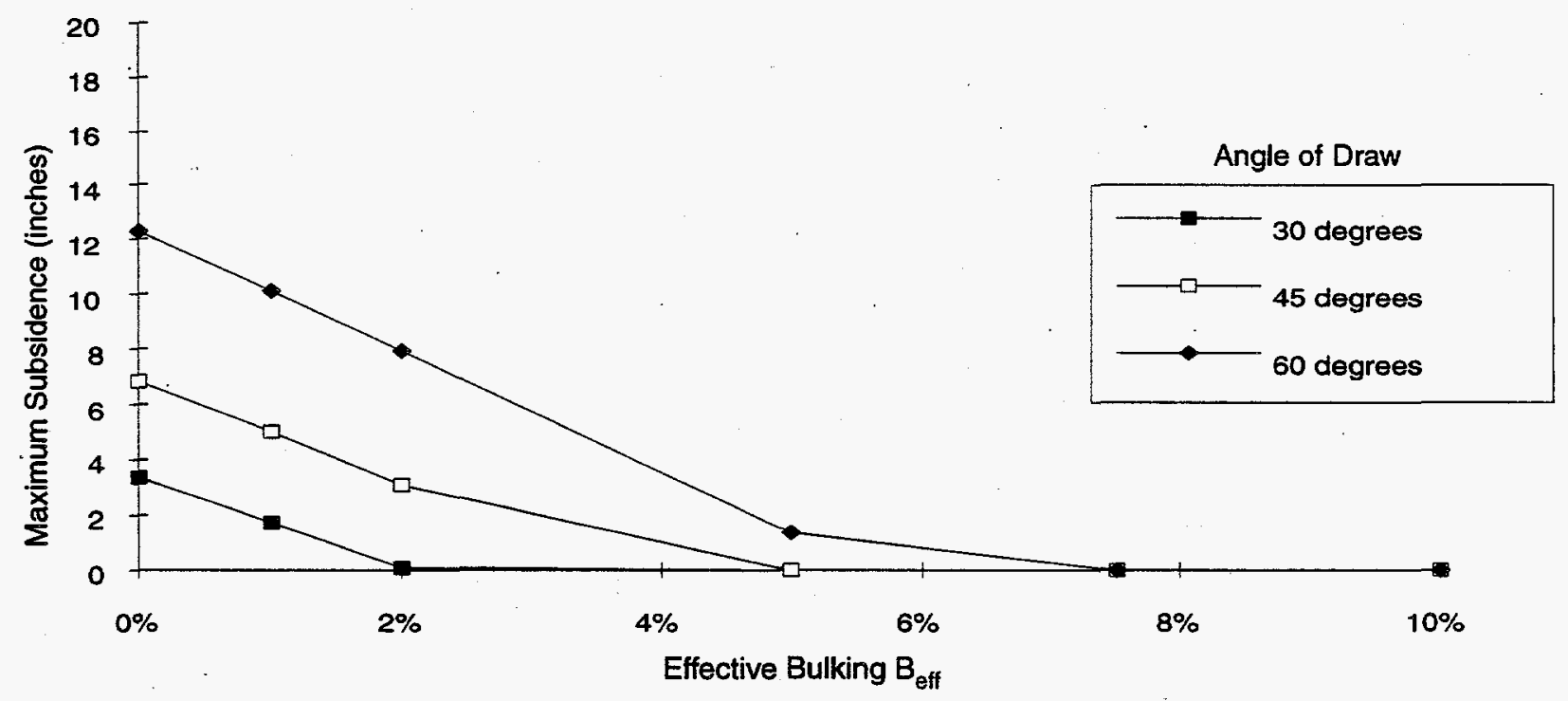

Assumptions

In Situ Porosity $22 \%$

ISV Melt Porosity $5 \%$

Depth 15'

Figure 3.7. Subsidence at Trough Center 


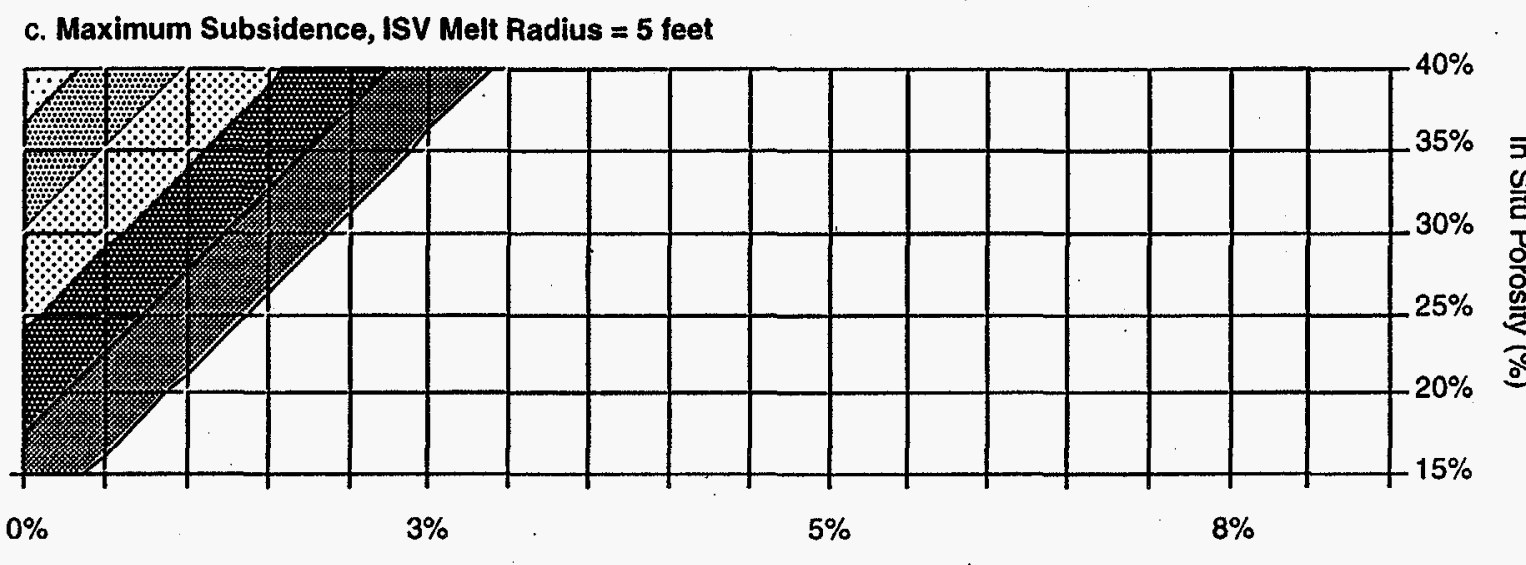

Effective Bulking $B_{\text {eff }}$

d. Maximum Subsidence, ISV Melt Radius $=10$ feet

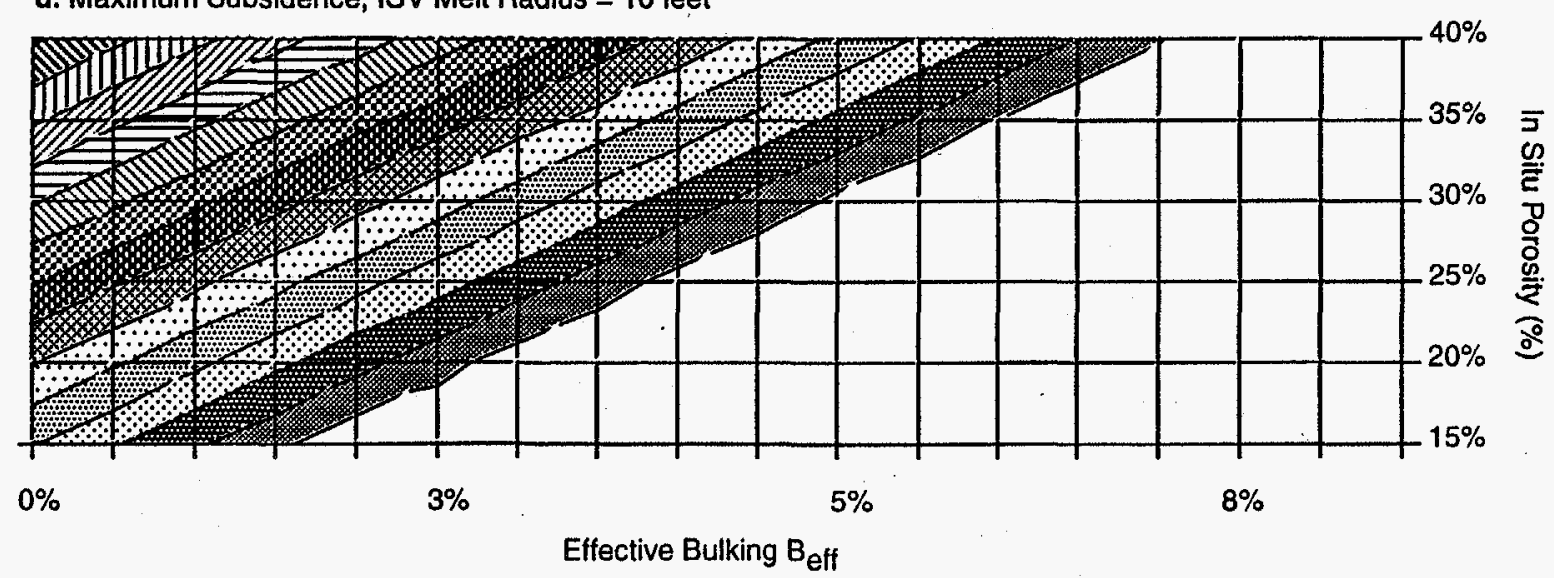

Subsidence (inches)

\begin{tabular}{|c|c|}
\hline$\unrhd 14-15$ & 6-7 \\
\hline $\mathbb{1}_{13-14}$ & 5-6 \\
\hline [III $12-13$ & 4-5 \\
\hline $11-12$ & 3-4 \\
\hline$\Theta_{10-11}$ & $2-3$ \\
\hline 9-10 & 1-2 \\
\hline $88-9$ & $\square 0-1$ \\
\hline $7 \cdot 8$ & \\
\hline
\end{tabular}

Assumption:

ISV Melt Porosity 5\%

Depth 15

Angle of Draw $45^{\circ}$

Figure 3.7. (contd) 
Table 3.2. Results of Probabilistic Analysis

Case

\begin{tabular}{ccc}
\multicolumn{4}{c}{ Surface Subsidence in Inches } \\
\hline $50 \%$ & $\mathbf{7 5 \%} \quad 90 \% \quad 95 \%$
\end{tabular}

$\underline{\text { Maximum }}$

Melt Radius in Feet

$\begin{array}{rrrrr}2.5 & 0.00 & 0.00 & 0.00 & 0.00 \\ 5 & 0.00 & 0.00 & 0.26 & 0.78 \\ 10 & 1.81 & 3.36 & 4.93 & 5.90 \\ 15 & 5.02 & 7.04 & 9.00 & 10.22\end{array}$

\section{At Hood Footings}

Melt Radius in Feet
5
0.00
0.00
0.19
0.55

Average

Melt Radius in Feet

$\begin{array}{ccccc}2.5 & 0.00 & 0.00 & 0.00 & 0.00 \\ 5 & 0.00 & 0.00 & 0.13 & 0.36 \\ 10 & 0.90 & 1.68 & 2.46 & 2.96 \\ 15 & 2.51 & 3.52 & 4.50 & 5.11\end{array}$

Notes:

1. See Appendix B for specific results.

2. Percentages represent the likelihood that the actual subsidence values will be less than the stated values.

3. Results assume insignificant melting of collapsing soils. 


\subsection{Horizontal Movements}

Horizontal movements during subsidence are near their maximum at the location of the proposed footings as shown in Figure 3.6. The magnitude of maximum horizontal movement at the surface during subsidence is generally in the range of 0.16 to 0.45 times the maximum vertical subsidence (Brauner 1973). According to Brauner, maximum horizontal displacement, HORmax, can be estimated as

$$
\mathrm{HOR}_{\max }=\frac{\mathrm{R}_{1} \ln 2}{2 \mathrm{H}} \delta_{\max }
$$

However, since vertical subsidence is not expected to be significant, horizontal movements are also not expected to be significant. For ISV applications, the off-gas hood should be of sufficient size, such as to extend beyond the footings shown in Figure 3.6, to allow for a margin of safety. 


\subsection{References}

Brauner, G. 1973. Subsidence Due to Underground Mining. U.S. Bureau of Mines Information Circular IC-8572, U.S. Bureau of Mines, Denver, Colorado.

Buelt, J. L., C. L. Timmerman, K. H. Oma, V. F. Fitzpatrick, and J. G. Carter. 1987. In Situ Vitrification of Transuranic Waste: An Update System Evaluation and Application Assessment. PNL-4800, Supplement 1, Pacific Northwest Laboratory, Richland, Washington.

Clarke, H. 1966. Handbook of Physical Constants for Rocks. Geological Society of America, Denver, Colorado.

Fang, H. Y. 1991. Foundation Engineering Handbook. Second Edition, Van Nostrand Reinhold, New York, New York.

Farmer, 1. 1968. Engineering Behavior of Rocks. Chapman and Hall, London, England.

Golder Associates Ltd and J.F. MacLaren, Ltd. 1976. Tunneling Technology: An Appraisal of the State of the Art for Application to Transit Systems. Ontario Ministry of Transportation and Communications, Toronto, Canada.

Golder Associates Inc. 1981. Skagit/Hanford Nuclear Power Plant Foundation Investigation. Appendix 2a, Report 803-1703, Golder Associates Inc., Redmond, Washington.

Lambe, T. W., and R. V. Whitman. 1969. Soil Mechanics. J. WIley and Sons Inc., New York, New York.

Luey, J., and D. K. Seiler. 1995. Application of In Situ Vitrification in the Soil Subsurface:

Engineering-Scale Testing. PNL-10485, Pacific Northwest Laboratory, Richland, Washington.

Luey, J., and D. K. Seiler. 1994. Evaluation of New Starter Path Geometries for In Situ Vitrification. PNL-10122, Pacific Northwest Laboratory, Richland, Washington.

Luey, J., J. S. Roberts, and C. L. Timmerman. 1993. "Implementation of In Situ Vitrification for Contaminated Soils." Presented at American Institute of Chemical Engineers 1993 Summer National Meeting, Seattle, Washington. PNL-SA-22008, Pacific Northwest Laboratory, Richland, Washington.

Luey, J., S. S. Koegler, W. L. Kuhn, P. S. Lowery, and R. G. Winkelman. 1992. In Situ Vitrification of a Mixed-Waste Contaminated Soil Site: The 116-B-6A Crib at Hanford. PNL8281 , Pacific Northwest Laboratory, Richland, Washington.

National Coal Board. 1975. Subsidence Engineer's.Handbook. National Coal Board Mining Department, London, England.

New Jersey Institute of Technology. 1995. Integration of Pneumatic Fracturing and In Situ Vitrification: Laboratory Study for Hanford Applications. PNL-10529, Pacific Northwest Laboratory, Richland, Washington. 
Obert, L., and W. I. Duvall. 1967. Rock Mechanics and the Design of Structures in Rock. J. Wiley and Sons Inc., New York, New York.

Pfleider, E. P. 1972. Surface Mining. AIME, New York, New York.

Tixier, J. S., J. A. Stottlemyre, and M. T. Murphy. 1991. Vitrified Underground Barriers. In Proceeding of Waste Management ' 91 Vol. 1, ed. R.G. Post, pp. 603-611. February 24-28, 1991, Tucson, Arizona.

Vutukuri, V. S., R. D. Lama, and S. S. Saluja. 1974. Handbook on Mechanical Properties of Rocks. Trans Tech Publications, London, England.

WPPSS. 1974. Preliminary Safety Analysis Report. WPPSS Nuclear Project No. 1, Vol. 1. WPPSS, Richland, Washington. 


\section{Appendix A}

Failure of Fused Zone And Overlying Soils 


\section{Appendix A}

\section{Failure of Fused Zone And Overlying Soils}

This appendix presents a simplified structural analysis carried out to determine the stability of fused and altered soil layers above the void created by in situ vitrification. This analysis is based on the methods used for evaluating subsidence above mined areas (see e.g., Obert and Duvall 1967). The analysis combines calculation of stresses on the fused and altered layers based on arching theory with a strength analysis based on elasticity theory (Timoshenko and Goodier 1934) and composite material theory (MacGregor 1988). Strength analyses are presented for both the fused layer itself and for the combination of the fused and altered layers.

\section{A.1 Strength Analysis Of Fused Zone}

The stiffness of the 2-in.-thick fused layer is expected to be several orders of magnitude greater than that for the altered zone. As a result, stress will concentrate within the fused zone, and the altered zone is expected to increase stability primarily through stress redistribution in compression. Therefore, the first strength analysis carried out reflects only the strength of the fused zone.

The strength of the fused zone is analyzed as follows: Timoshenko and Goodier (1934) analyzed the stresses on a circular disk supported at its edges, Figure A.1. They calculated the radial tensile stress, $\sigma_{\mathrm{r}}$, on this zone using the Equation (A.1),

$$
\sigma_{\mathrm{r}}=\frac{3(3+v)}{32}\left(\frac{\mathrm{R}_{1}^{2} \mathrm{z}}{\mathrm{t}^{3}}\right) \mathrm{q}
$$

where $t$ is one half the thickness of the fused zone, $z$ is the depth of the point of consideration beneath the center of the fused zone, $R_{1}$ is the radius of the fused zone, $v$ is Poisson's ratio, and $q$ is the stress due to overlying materials. 
a. Failure of Fused Zone under overburden weight.

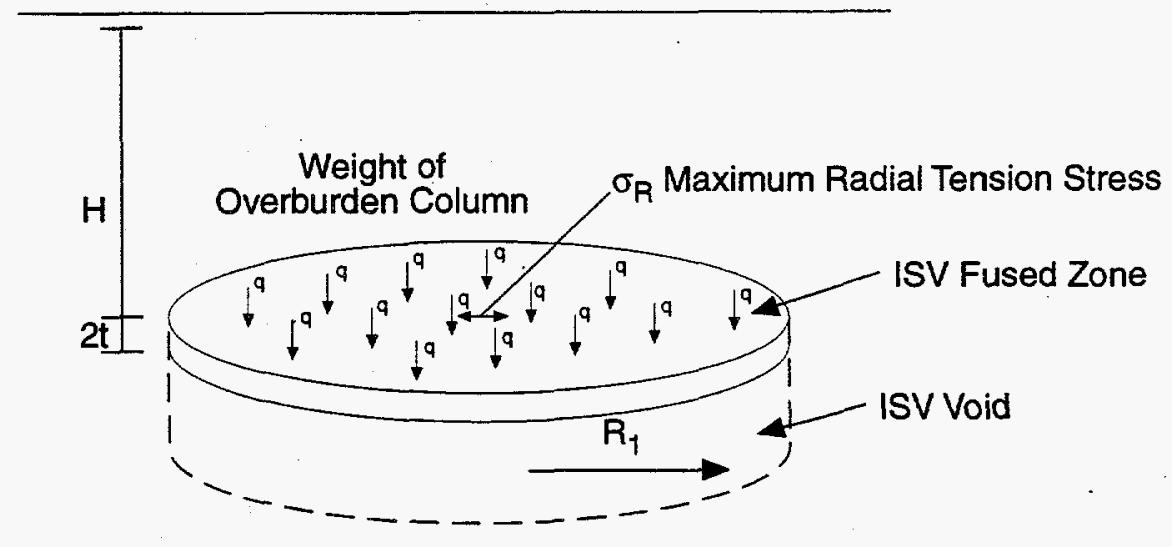

b. Failure of Fused Zone with Arching

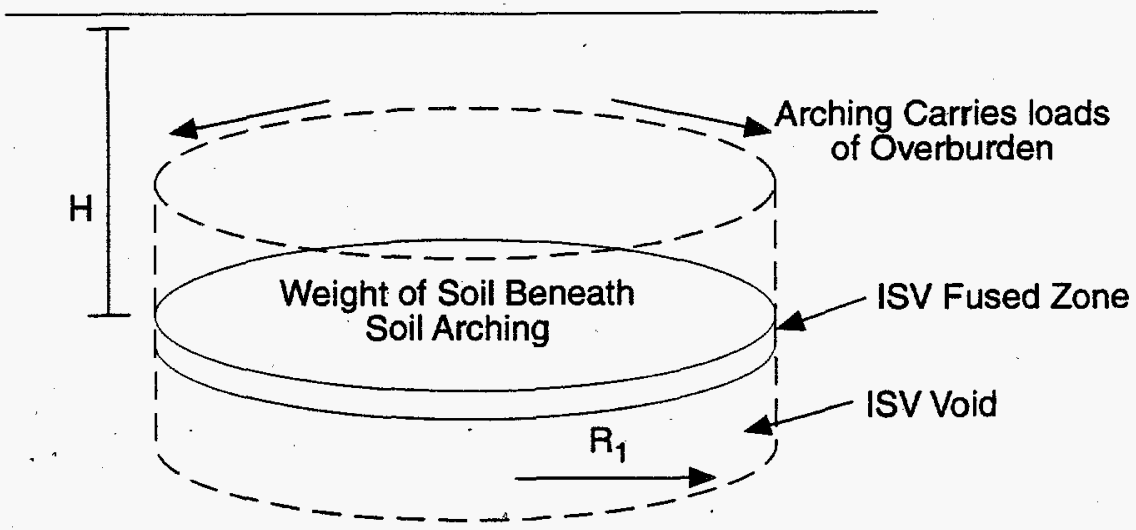

Figure A.1. Stress On Fused Soil

\section{A.2}


The maximum radial tensile stress, and therefore the initiation of failure, would occur at the bottom center of the disk,

$$
\sigma_{\mathrm{r}}=\frac{3(3+v)}{32}\left(\frac{\mathrm{R}_{1}^{2} \mathrm{q}}{\mathrm{t}^{2}}\right)
$$

The stability of the 2-in.-thick fused zone can be calculated using a factor of safety, defined as the ratio of the tensile strength of the material, $S_{\max }$, to the radial tensile stress, $\sigma_{\mathrm{r}}$. For the purposes of this analysis, the tensile strength will be estimated as 100,000 psf. The factor of safety then depends on the vertical stress q applied to the disk:

$$
\mathrm{F}_{\mathrm{s}}=\mathrm{S}_{\max } / \sigma_{\mathrm{r}}
$$

\section{A.2 Strength Analysis, Fused Zone And Altered Zones}

The approximately 2-in.-thick fused soils layer and the approximately 2-ft-thick altered soil layer could contribute to the support of the overlying soils. The combined strength of the two material can be calculated using "transformed section" approaches developed for analysis of composite materials such as steel-reinforced concrete. In this approach, the material strength is analyzed in a transformed geometry in which the sections are scaled to account for their varying stiffness (MacGregor 1988). This analysis is illustrated in Figure A.2.

Until failure occurs, the composite material (fused plus altered soils) is assumed to be linearlyelastic. The fundamental assumption of linear-elastic bending theory is that strains are linearly distributed over the depth of each member. When a beam consisting of materials with different elastic moduli is loaded, this leads to a different stress distribution because the stiffer material accepts more stress for a given strain. In order to carry out elastic analyses, a transformed section is created consisting of a single material with a constant elastic modulus. To maintain the correct stiffness, the area of the transformed material is adjusted by the ratio,

$$
R_{t}=R\left(\frac{E_{a}}{E_{f}}\right)
$$

where $E_{a}$ and $E_{f}$ are the elastic moduli of the altered and fused soils, respectively, and $R$ and $R_{t}$ are the ISV melt radius and the transformed radius for the altered soils, respectively. 
a. Analysed Geometry

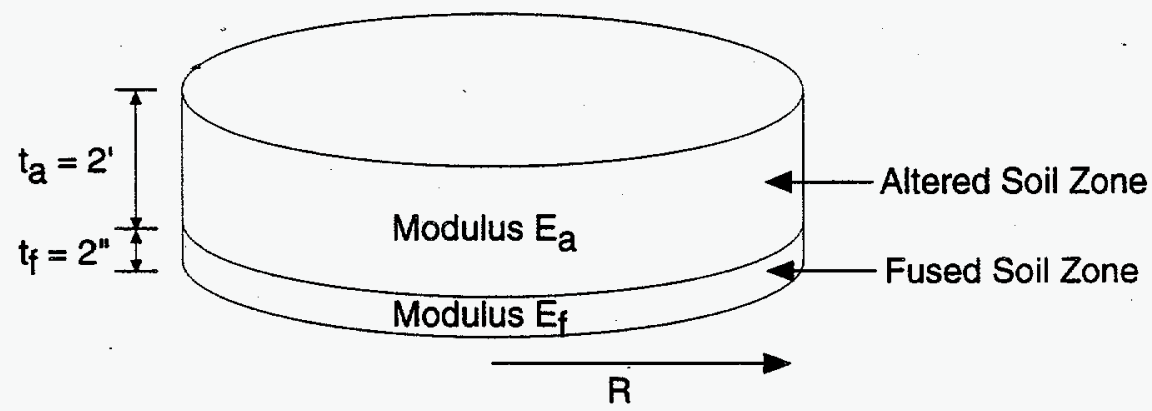

b. Transformed Geometry

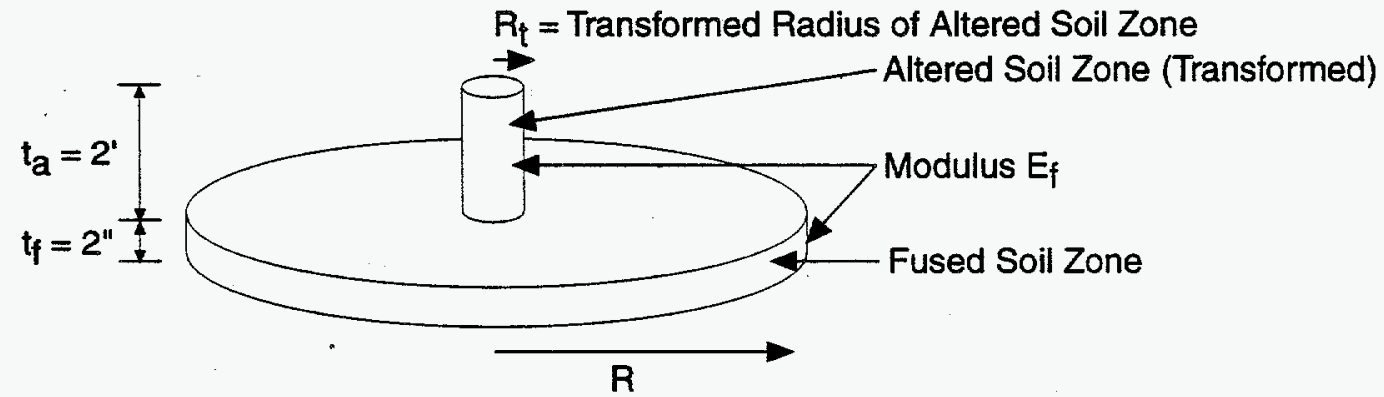

c. Transformed Section

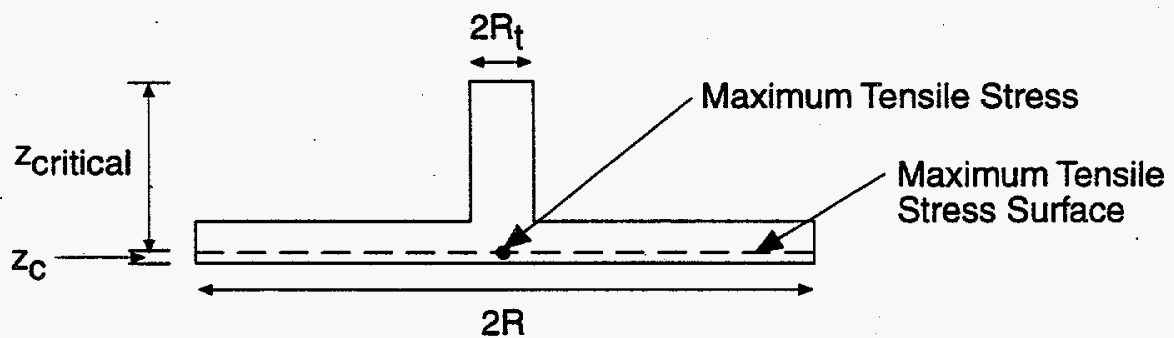

Figure A.2. Composite Analysis Of Fused And Altered Zone

A. 4 
The location of the neutral (centroid axis) within the transformed composite material, $\mathrm{z}_{\text {crit, }}$, can then be calculated from the ratio of the first moment of the transformed section, $Q_{t}$, to the area of the transformed section, $A_{t}$,

$$
\mathrm{z}_{\text {crit }}=\frac{\mathrm{Q}_{\mathrm{t}}}{\mathrm{A}_{\mathrm{t}}}
$$

where $z_{c r i t}$ is measured from the top of the altered material. The moment and the area are calculated from the respective thickness of the fused and altered soils $t_{t}$ and $t_{a}$, and the radii of the fused and altered soils, $R$ and $R_{t}$,

$$
\begin{aligned}
A_{t} & =A_{a t}+A_{f} \\
A_{a t} & =2 R_{t} t_{a} \\
A_{f} & =2 R t_{f} \\
Q_{t} & =A_{a t} \frac{t_{a}}{2}+A_{f}\left(t_{a}+\frac{t_{f}}{2}\right) \\
Q_{t} & =R_{t} t_{a}^{2}+R t_{f}\left(2 t_{a}+t_{f}\right)
\end{aligned}
$$

Combining Equations (A.5) through (A.7), the location of the centroidal axis can be expressed as

$$
z_{\text {crit }}=\frac{R_{t} t_{a}^{2}+R_{t_{f}}\left(2 t_{a}+t_{f}\right)}{2\left(R_{t} t_{a}+R t_{f}\right)}
$$

The average stress, $\sigma_{\mathrm{Rav}}$, on the transformed section at the location of failure (i.e., the bottom of the fused layer) can be calculated from the Equation,

$$
\sigma_{\mathrm{Rav}}=\frac{\mathrm{M}_{\mathrm{t}} \mathrm{z}_{\mathrm{c}}}{\mathrm{I}_{\mathrm{t}}}
$$

where $I_{t}$ is the moment of inertia of the transformed section, $M_{t}$ is the moment applied to the transformed section, and $z_{c}$ is the centroidal distance from the bottom of the layer. 
The moment of inertia $I_{t}$ on the transformed section is calculated as,

$$
I_{t}=A_{a t}\left(z_{c r i t}-\frac{t_{a}}{2}\right)^{2}+A_{f}\left(\frac{t_{f}}{2}+t_{a}-z_{c r i t}\right)^{2}+2\left(\frac{R_{t} t_{a}^{3}+R t_{f}^{3}}{12}\right)
$$

The moment on the transformed section at location of failure, $M_{t}$, can then be derived from movement equilibrium of the simply-supported disk of altered and fused soils, assuming that the overburden stress $q$ is applied at the top of the section,

$$
M_{t}=q \frac{R^{3}}{3}
$$

The centroidal distance from the bottom of the transformed section $z_{c}$ is the distance of

$$
\mathrm{z}_{\mathrm{c}}=\mathrm{t}_{\mathrm{a}}+\mathrm{t}_{\mathrm{f}}-\mathrm{z}_{\mathrm{crit}}
$$

The average tensile stress $\sigma_{\mathrm{Rav}}$ on the transformed section at the extreme bottom fiber can be expressed by combining Equations (A.9) through (A.12).

The failure stress $\sigma_{R}$ for the composite material will be the stress at the center of the section, and for linear elastic material, it may be related to the average stress $\sigma_{\text {Rav }}$ through Poisson's ratio, as

$$
\sigma_{\mathrm{R}}=\sigma_{\mathrm{Rav}}\left[6 \frac{(3+v)}{16}\right]
$$

Since the altered soil will contribute part of the overburden weight, loading the combined section, Equation (A.11) is valid for overburden thickness significantly greater than the thickness of the altered soil zone. The load provided by the altered zone can be approximated using the principle of superposition,

$$
\sigma_{\text {Rav }}(\text { total })=\sigma_{\text {Rav }}\left(\mathrm{q}, \mathrm{t}_{\mathrm{a}}\right)+{\underset{\mathrm{i}}{3}=1}^{4} \sigma_{\operatorname{Rav}}\left(\mathrm{q}(\mathrm{i}), \mathrm{t}_{\mathrm{a}} \mathrm{i} / 4\right)
$$

where $\sigma_{\mathrm{Rav}}($ total $)$ is the total stress on the failure plane, $\sigma_{\mathrm{Rav}}\left(\mathrm{q}, \mathrm{t}_{\mathrm{a}}\right)$ is the stress on the failure plan due to overburden applied at the top of the altered soil zone, and $\sigma_{\mathrm{Rav}}\left(\mathrm{q}(\mathrm{i}), \mathrm{t}_{\mathrm{a}} \mathrm{i} / 4\right)$ is the stress due 
to the weight of the soil in the $i$ 'th slice of altered soil. Note that the transformed section is different for each slice of altered soil.

This approximation will be used to estimate the factor of safety using Equation (A.2) with the stress at failure defined by Equation (A.13).

\section{A.3 Stress Applied To Fused And Altered Soil Layers}

The stress $\mathrm{q}$ on the fused zone at failure was estimated using two alternative assumptions for the mode of failure.

1) Until deformation occurs above the ISV melt, the weight of a vertical column of soil to the surface must be supported directly by the strength of the 2-in.-thick fused soil ("obsidian") at the top of the melt.

2) Once deformation begins, the horizontal stresses within the soil above the melt increase, providing a soil strength to support the overlying support and supporting a portion of the overlying soils through an arching mechanism.

\section{A.3.1 Simple Stress Estimate}

With no movement in the overlying materials, the stress q due to the overlying materials can be estimated as

$$
q=\gamma H
$$

This is the simplest assumption and should be considered overly conservative, because arching, described in the next section, generally limits the maximum soil load on a tunnel to approximately 2 to 3 times the tunnel radius. For a cavern, which has a three-dimensional geometry, the soil load should be even smaller.

\section{A.3.2 Arching Stress Estimate}

With slight movement of the overlying materials, arching occurs, reducing the net stress on the 2-in.-thick fused zone by transferring the weight of these material through horizontal stresses.

$$
\begin{gathered}
\mathrm{q} \approx \gamma \mathrm{R}_{1} \mathrm{a} \\
\mathrm{a} \approx \frac{1}{\mathrm{~K} \tan \phi}\left(1-\mathrm{e}^{-\mathrm{K}\left(\mathrm{R}_{1} / \mathrm{H}\right) \tan \phi}\right)
\end{gathered}
$$


The factors " $K$ " and " $a$ " above were introduced to account for the effect of arching. In an underground tunnel beneath cohesive soils, the maximum stress on the tunnel is defined by a soil column 2 to 2.5 times the tunnel radius, not the total soil column to the surface. $\mathrm{K}$ represents the horizontal stress above the tunnel as a percentage of the geostatic stress gamma $\mathrm{H}$. The factor a represents the effect of arching.

For deep tunnels or caverns, the arching stress should be increased to include a component of load on the soil arch from overlying soils. However, the above equation is appropriate for the range of depth-to-cavern radius being considered for ISV.

\section{A.4 Results Of Analysis}

The factor of safety for two overburden stress levels with and without arching are plotted for the failure in the fused soils alone in Figures A.3a and A.3b, and for the composite strength of fused and altered soils in Figures A.4a and A.4b. These factors of safety were calculated using the maximum likelihood values of tensile strength for fused soils, $100,000 \mathrm{psf}$. For the simple analysis at a depth of $15 \mathrm{ft}$, a factor of safety of 1 (failure) is reached for a radius of approximately $1.5 \mathrm{ft}$ for the fused soils alone, and a radius of $2.5 \mathrm{ft}$ for the fused and altered soils. For the analysis including arching, a factor of safety of 1 is reached for a radius of approximately $3 \mathrm{ft}$ for the fused soils alone and $4.5 \mathrm{ft}$ for the fused and altered soils.

An Excel/Crystal Ball stochastic simulation was carried out to calculate the probability of failure, based on an assumption of arching with $\mathrm{K}=1.0$. This analysis assumed triangular distributions for friction angle and maximum tensile strength for the fused soil with minimum and maximum likelihood, and maximum values.

For the analysis with strength provided solely by the fused soils, the probability of failure is less than $1 \%$ for melt radii less than $2 \mathrm{ft}$. The probability of failure is approximately $50 \%$ for a melt radius of $2.5 \mathrm{ft}$. The probability of failure exceeds $99 \%$ for all ISV melt radius greater than $4 \mathrm{ft}$.

For the analysis with strength provided solely by the composite of altered and fused soils, the probability of failure is less than $1 \%$ for melt radii less than $3 \mathrm{ft}$. The probability of failure is approximately $50 \%$ for a melt radius of $4 \mathrm{ft}$. The probability of failure exceeds $99 \%$ for all ISV melt radius greater than $5 \mathrm{ft}$. 


\section{a. Failure of Fused Zone - No Displacement}

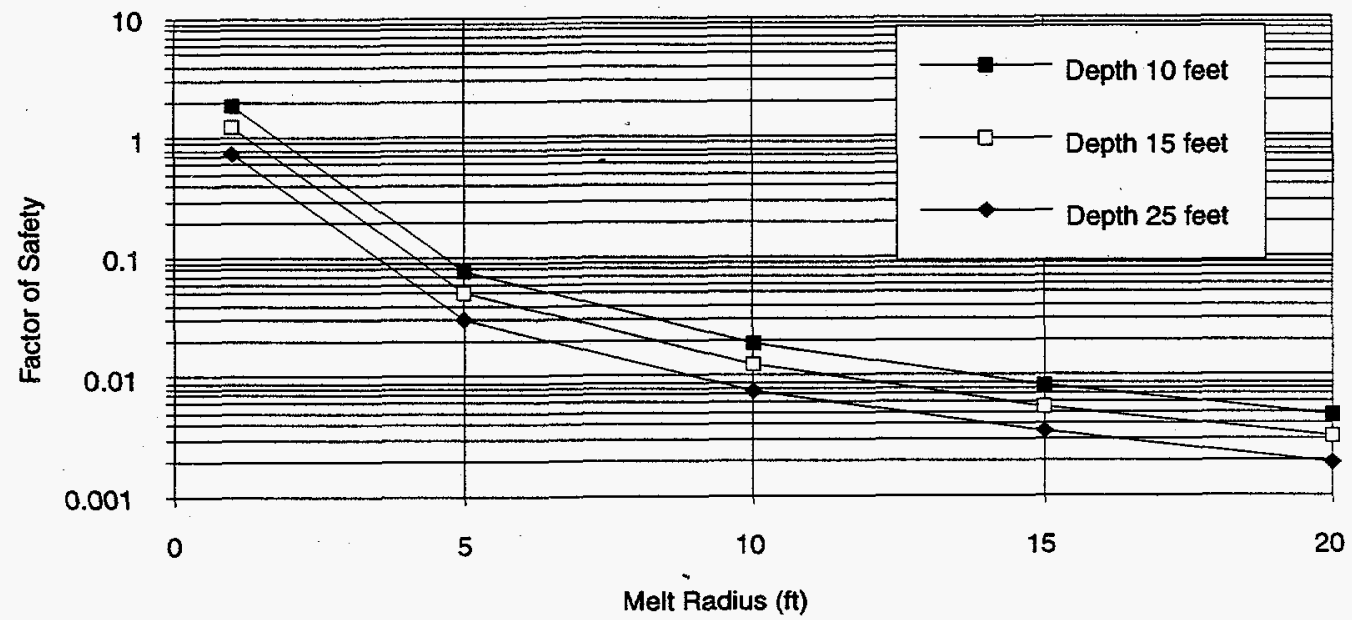

b. Failure of Fused Zone With Arching

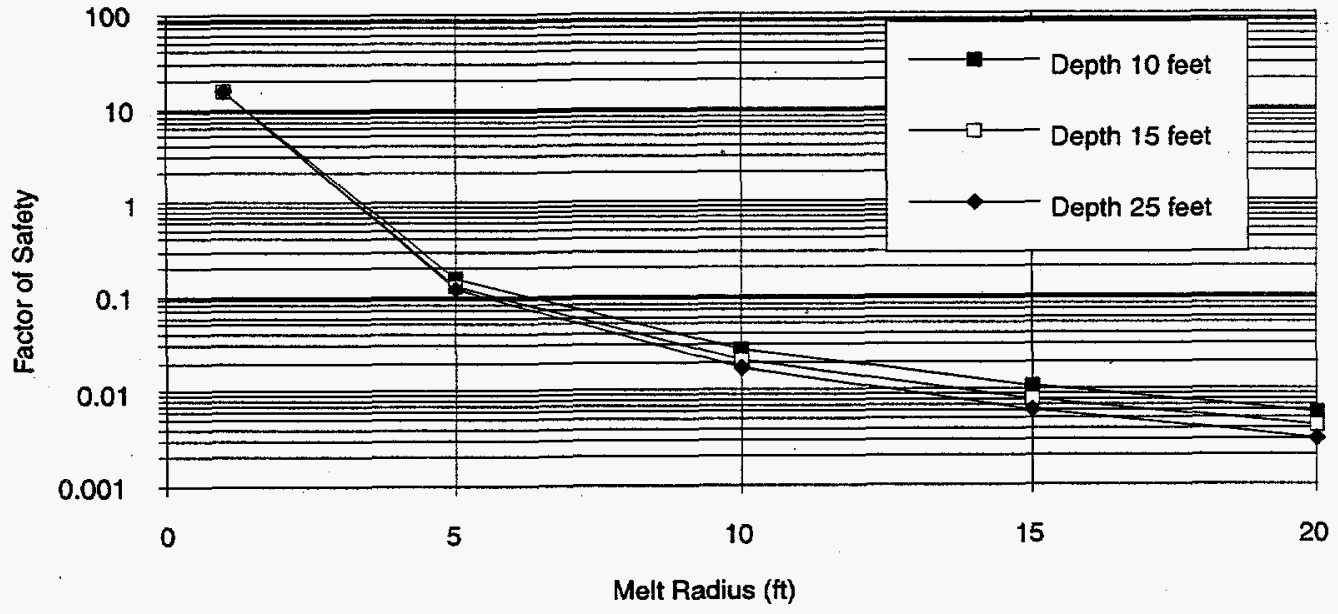

Figure A.3. Failure Of Fused Zone

A.9 
a. Failure of Fused and Altered Zones - No Displacement

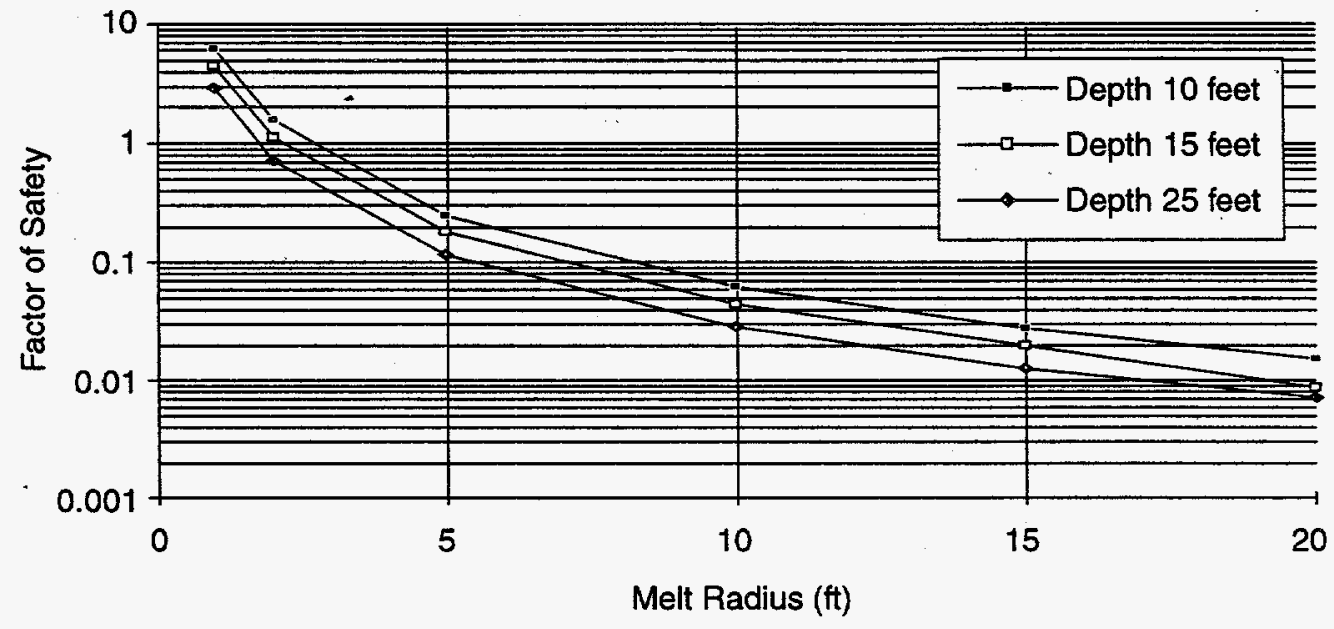

\section{b. Failure of Fused and Altered Zones with Arching}

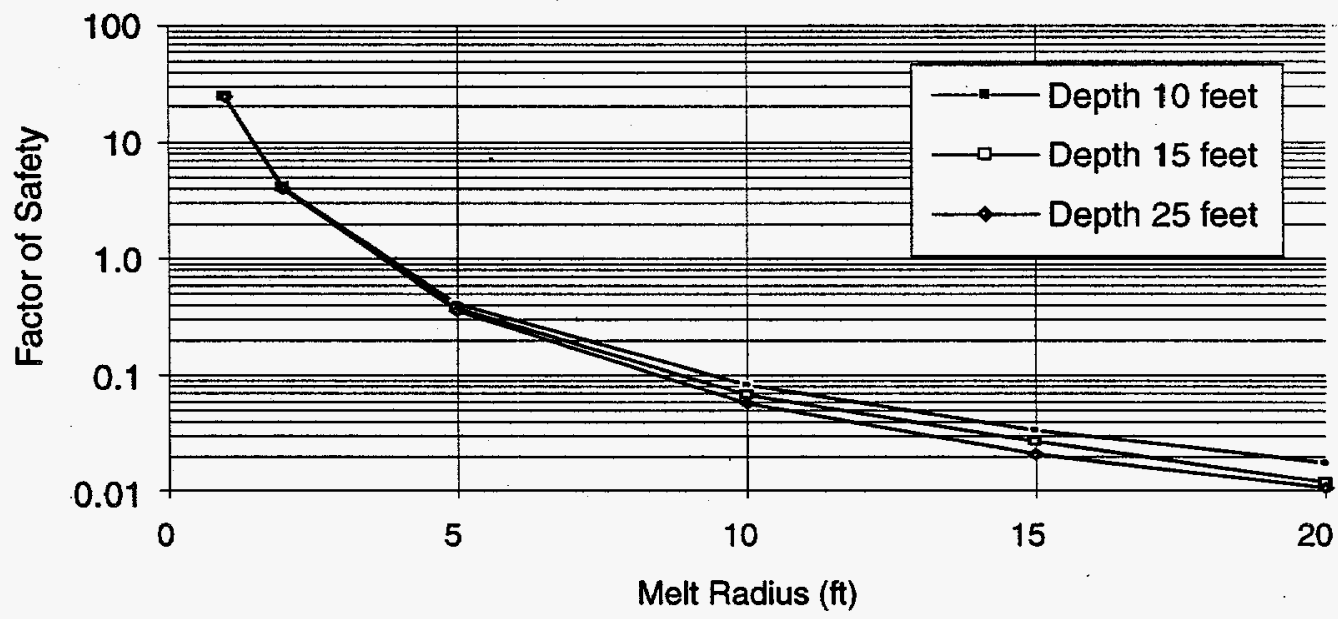

Figure A.4. Failure Of Composite Fused And Altered Zones 


\section{A.5 References}

MacGregor, J. G. 1988. Reinforced Concrete Mechanics and Design. Prentice Hall, Englewood Cliffs, New Jersey.

Obert, L. and W. I. Duvall. 1967. Rock Mechanics and the Design of Structures in Rock. J. Wiley and Sons Inc., New York, New York.

Timoshenko, S., and J. Goodier. 1934. Theory of Elasticity. McGraw-Hill Book Company, New York, New York. 
Appendix B

Monte Carlo Simulations 


\section{Summary:}

Display Range is from 0 to $0.045 \mathrm{ft}$

Entire Range is from 0.000000033387247316 to $0.1498029515393173 \mathrm{ff}$ After 13,500 Trials, the Std. Error of the Mean is 0.00011998164651324

Statistics:

Trials

Value

Mean

13500

Median (approx.)

Mode (approx.)

Standard Deviation

Variance

Skewness

Kurtosis

Coeff. of Variability

0.004096484

0.000288609

0.000749048

0.013940608

0.000194341

4.409392747

25.31464429

3.403066532

Range Minimum

3.33872E-08

Range Maximum

0.149802952

Range Width

0.149802918

Mean Std. Error

0.000119982

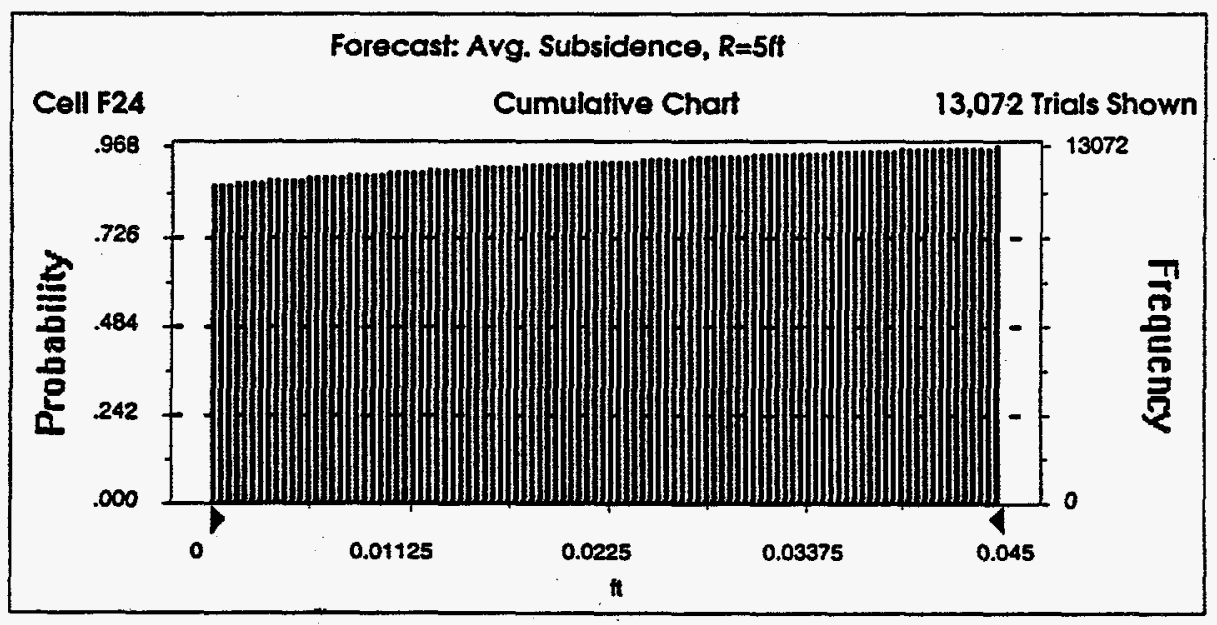

B.1 
Forecast: Avg. Subsidence, $R=5 \mathrm{ft}$ (cont'd)

Cell: $\mathbf{F 2 4}$

Percentiles:

Percentile

$0 \%$

$5 \%$

$25 \%$

$50 \%$

$75 \%$

$95 \%$

$100 \%$ it (approx.)

3.33872E-08

2.8891E-05

0.000144321

0.000288609

0.000432897

0.032374108

0.149802952

End of Forecast

B. 2 
Summary:

Display Range is from 0 to $0.35 \mathrm{ft}$

Entire Range is from 0.00000002496755177 to $0.50431966435092768 \mathrm{ft}$

After 13,500 Trials, the Std. Error of the Mean is 0.000698864041943592

Statistics:

Trials

Value

Mean

13500

Median (approx.)

0.089934427

Mode (approx.)

0.075398308

Standard Deviation

0.002521623

Variance

0.081200664

Skewness

0.006593548

Kurtosis

0.892427659

Coeff. of Variability

3.383018188

0.902887431

Range Minimum

2.49676E-08

Range Maximum

0.504319664

Range Width

0.504319639

Mean Std. Error

0.000698864

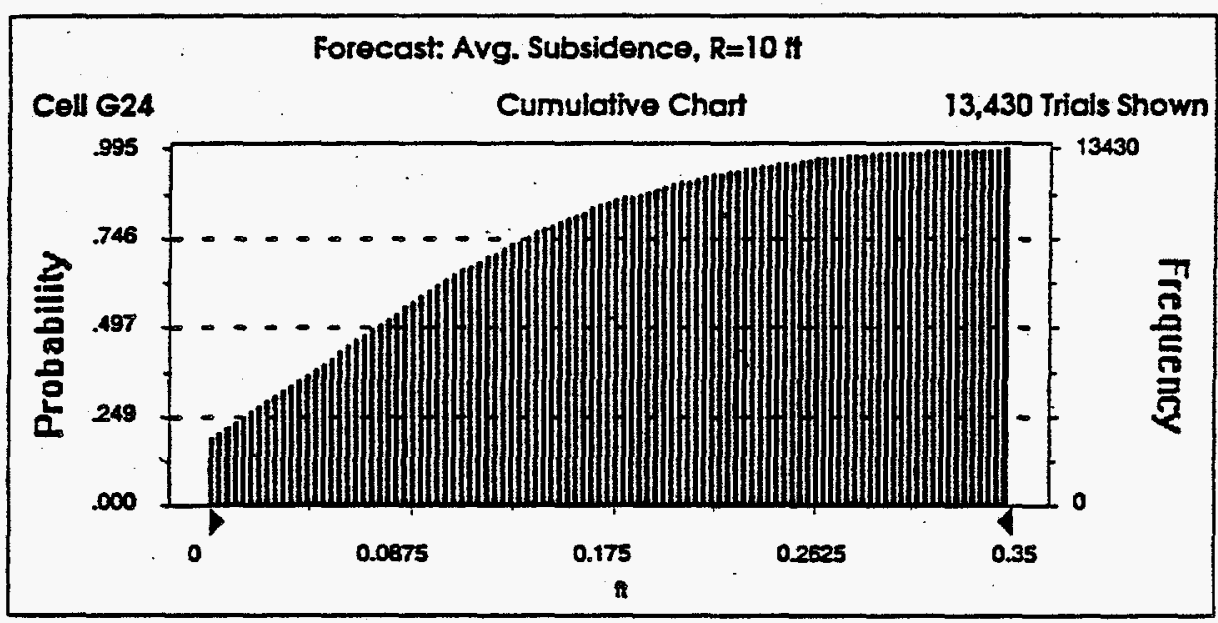

B. 3 
Forecast: Avg. Subsidence, $R=10 \mathrm{ft}$ (cont'd)

Cell: $\mathbf{6 2 4}$

Percentiles:

\begin{tabular}{r} 
Percentile \\
\hline $0 \%$ \\
$5 \%$ \\
$25 \%$ \\
$50 \%$ \\
$75 \%$ \\
$95 \%$ \\
$100 \%$
\end{tabular}

\begin{tabular}{r} 
ft (oporox.) \\
\hline $2.49676 E-08$ \\
0.00044155 \\
0.017729039 \\
0.075398308 \\
0.140196279 \\
0.246156039 \\
0.504319664
\end{tabular}

End of Forecast

B.4 
Summary:

Display Range is from 0 to $0.55 \mathrm{ft}$

Entire Range is from 0.00000001920699933 to $0.70054127909439556 \mathrm{ft}$

After 13,500 Trials, the Std. Error of the Mean is 0.001016717064956812

Statistics:

Trials

Mean

Median (approx.)

Mode (approx.)

Standard Deviation

Variance

Skewness

Kurtosis

Coeff. of Variability

Range Minimum

Range Maximum

Range Width

Mean Std. Error
Value

13500

0.216711248

0.208784666

0.003502726

0.118131848

0.013955133

0.393813862

2.896721457

0.54511175

$1.9207 \mathrm{E}-08$

0.700541279

0.70054126

0.001016717

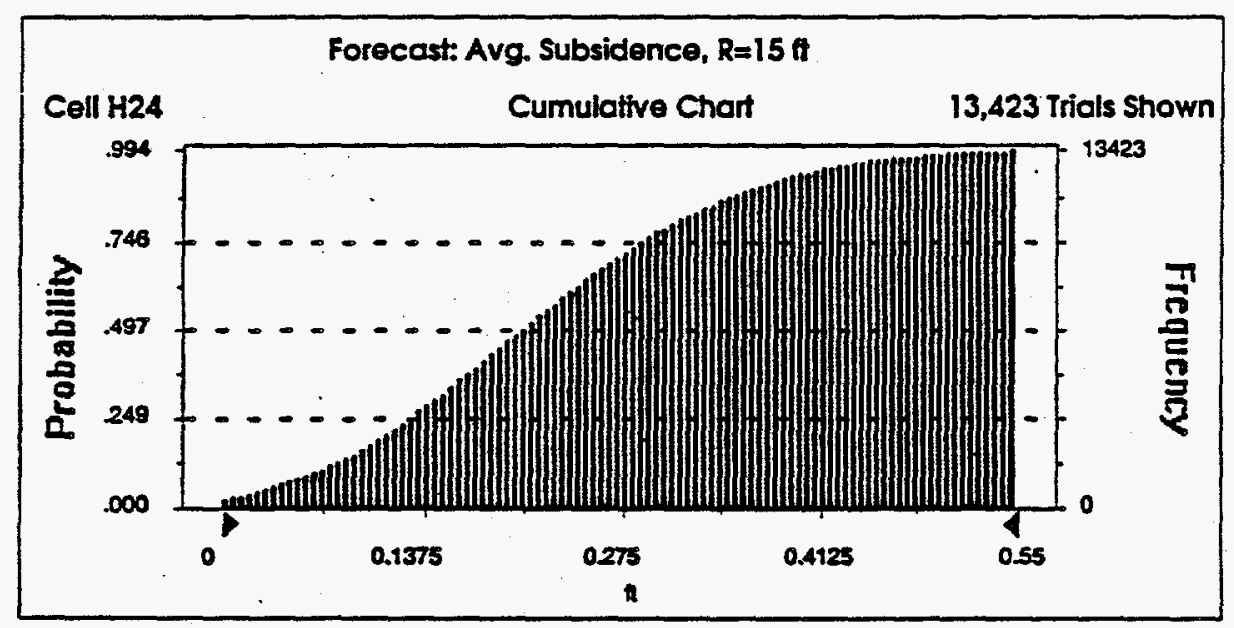

B.5 
Forecast: Avg. Subsidence, $R=15 \mathrm{ft}$ (cont'd)

\title{
Cell: H24
}

Percentiles:

\begin{tabular}{r} 
Percentile \\
\hline $0 \%$ \\
$5 \%$ \\
$25 \%$ \\
$50 \%$ \\
$75 \%$ \\
$95 \%$ \\
$100 \%$
\end{tabular}

\begin{abstract}
A (approx.)
$1.9207 E-08$

0.03078924

0.131069915

0.208784666

0.29349544

0.425995823

0.700541279
\end{abstract}

End of Forecast 
Summary:

Disploy Range is from 0 to $0.09 \mathrm{ft}$

Entire Range is from 0.000000066774494632 to $0.29960590307863461 \mathrm{ft}$

After 13.500 Trials, the Std. Error of the Mean is 0.00023996329302648

Statistics:

Trials

Value

13500

Mean

0.008192968

Median (approx.)

0.000577218

Mode (approx.)

0.001498096

Standard Deviation

0.027881215

Variance

0.000777362

Skewness

4.409392747

Kurtosis

25.31464429

Coeff. of Variability

3.403066532

Range Minimum

$6.67745 E-08$

Range Maximum

0.299605903

Range Width

0.299605836

Mean Std. Error

0.000239963

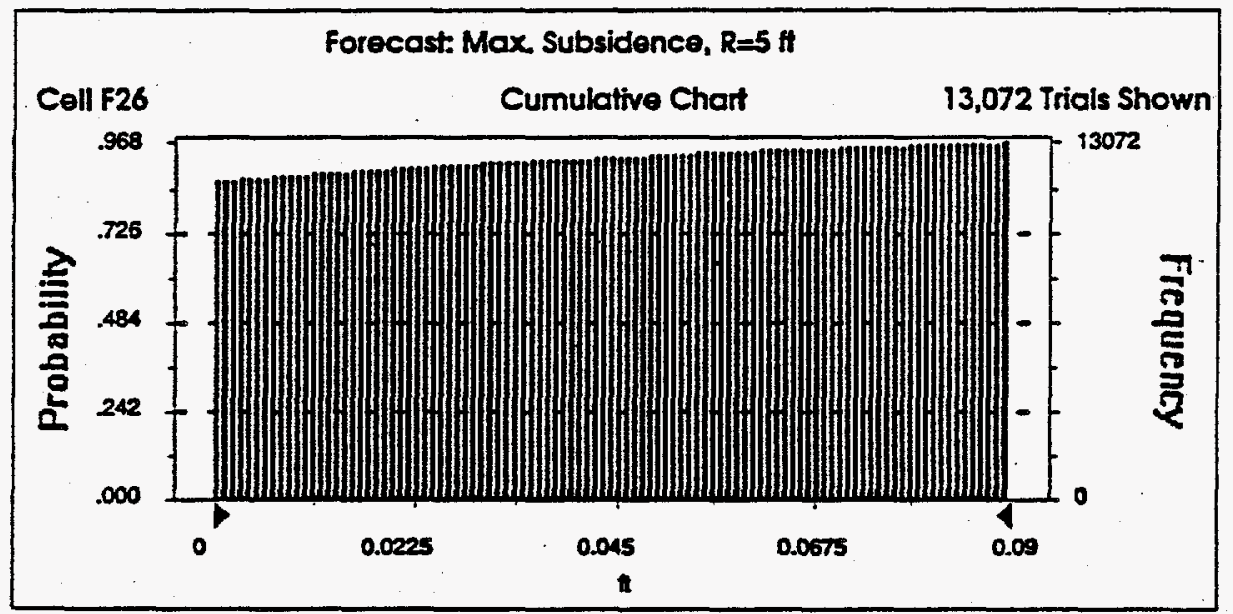

B.7 
Forecast: Max. Subsidence, $R=5 \mathrm{ft}$ (cont'd)

Cell: $F 26$

Percentiles:

\begin{tabular}{r} 
Percentile \\
\hline $0 \%$ \\
$5 \%$ \\
$25 \%$ \\
$50 \%$ \\
$75 \%$ \\
$95 \%$ \\
$100 \%$
\end{tabular}

tt(approx.)

6.67745E-08

5.77819E-05

0.000288643

0.000577218

0.000865794

0.064748217

0.299605903

End of Forecast

B. 8 
Summary:

Display Range is from 0 to $0.7 \mathrm{ft}$

Entire Range is from 0.000000049935103541 to $1.00863932870185535 \mathrm{ft}$ After 13,500 Trials, the Std. Error of the Mean is 0.001397728083887184

\section{Statistics:}

Trials

Mean

Median (approx.)

Mode (approx.)

Standard Deviation

Variance

Skewness

Kurtosis

Coeff. of Variability

Range Minimum

Range Maximum

Range Width

Mean Std. Error
Value

13500

0.179868854

0.150796615

0.005043246

0.162401328

0.026374191

0.892427659

3.383018188

0.902887431

4.99351E-08

1.008639329

1.008639279

0.001397728

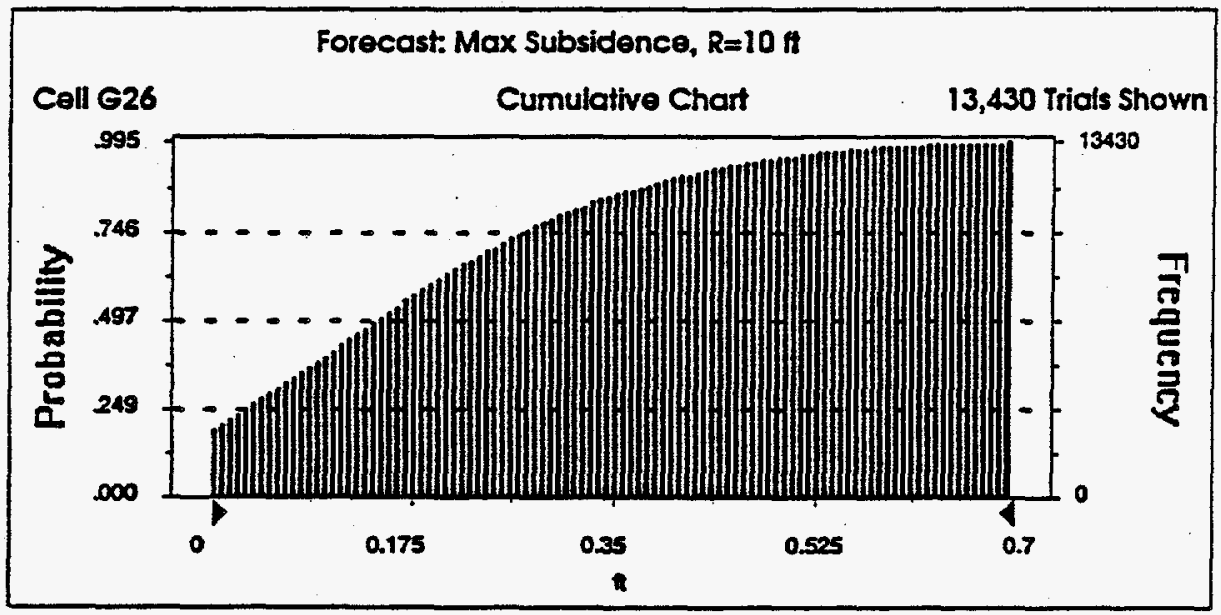

B.9 
Forecast: Max Subsidence, $R=10$ ft (cont'd)

Percentiles:

\begin{tabular}{r} 
Percentile \\
\hline $0 \%$ \\
$5 \%$ \\
$25 \%$ \\
$50 \%$ \\
$75 \%$ \\
$95 \%$ \\
$100 \%$
\end{tabular}

ft (approx.) 4.99351E-08 0.0008831 0.035458079

0.150796615

0.280392558

0.492312079

1.008639329

End of Forecost 
Summary:

Display Range is from 0 to $1.1 \mathrm{ft}$

Entire Range is from 0.000000038413998659 to $1.40108255818879113 \mathrm{ft}$

After 13,500 Trials, the Std. Error of the Mean is 0.002033434129913625

Statistics:

Trials

Value

Mean

13500

Mean

Median (approx.)

0.433422497

Mode (approx.)

0.417569332

Standard Deviation

0.007005451

Variance

0.236263696

Skewness

0.055820534

Kurtosis

0.393813862

2.896721457

Coeff. of Variability

0.54511175

Range Minimum

$3.8414 \mathrm{E}-08$

Range Maximum

1.401082558

Range Width

1.40108252

Mean Std. Error

0.002033434

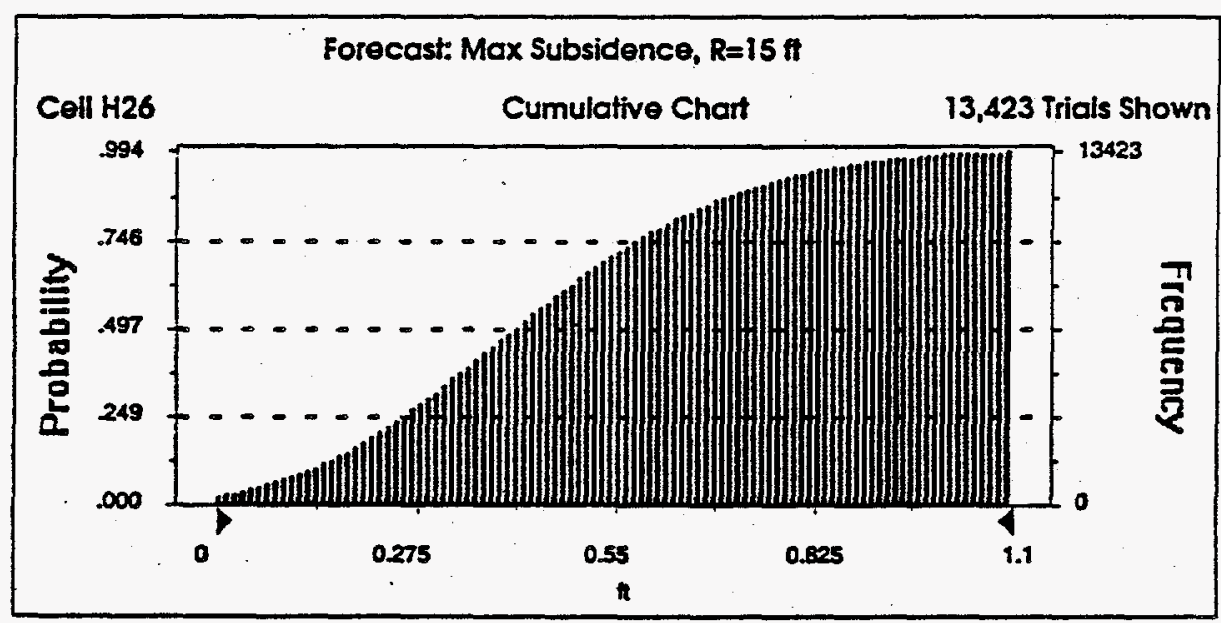


Forecast: Max Subsidence, $R=15$ it (cont'd)

Cell: $\mathrm{H} 26$

Percentiles:

\begin{tabular}{r} 
Percentile \\
\hline $0 \%$ \\
$5 \%$ \\
$25 \%$ \\
$50 \%$ \\
$75 \%$ \\
$95 \%$ \\
$100 \%$
\end{tabular}

\begin{tabular}{r} 
tt(approx.) \\
\hline $3.8414 E-08$ \\
0.06157848 \\
0.262139831 \\
0.417569332 \\
0.586990879 \\
0.851991647 \\
1.401082558
\end{tabular}

End of Forecast

B. 12 
Summary:

Disploy Range is from 0 to $0.055 \mathrm{ft}$

Entire Range is from 0.000000060251643046 to $0.18124377384150667 \mathrm{ft}$

After 13.500 Trials. the Std. Error of the Mean is 0.000162029820129344

Statistics:

Trials

$\underline{\text { Value }}$

13500

Mean

0.005643829

Median (approx.)

0.000349382

Mode (approx.)

0.000906279

Standard Deviation

0.018826164

Variance

0.000354424

Skewness

4.194770629

Kurtosis

22.69547018

Coeff. of Variability

3.335707838

Range Minimum

$6.02516 E-08$

Range Maximum

0.181243774

Range Width

0.181243714

Mean Std. Error

0.00016203

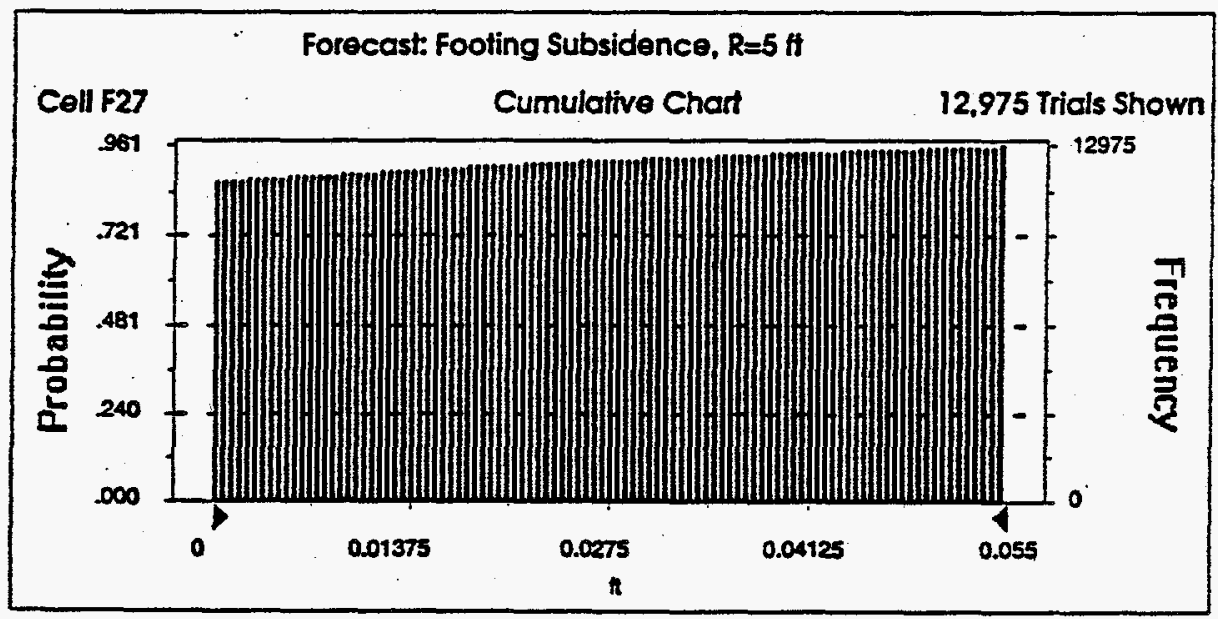

B.13 
Forecast: Footing Subsidence, $R=5 \mathrm{ft}$ (cont'd)

Percentiles:

Percentile
$0 \%$
$5 \%$
$25 \%$
$50 \%$
$75 \%$
$95 \%$
$100 \%$

At (approx.)

6.02516E-08

3.49924E-05

0.000174721

0.000349382

0.000524043

0.045822189

0.181243774

End of Forecast

B.14 
Summary:

Display Range is from 0 to $0.5 \mathrm{ft}$

Entire Range is from 0.000000046240457277 to $0.76820281545647207 \mathrm{ft}$ Affer 13,500 Trials, the Std. Error of the Mean is 0.001127318996269674

$\begin{array}{lr}\text { Statistics: } & \text { Value } \\ \text { Trials } & 13500 \\ \text { Mean } & 0.149370454 \\ \text { Median (approx.) } & 0.129297108 \\ \text { Mode (approx.) } & 0.00384106 \\ \text { Standard Deviation } & 0.130982631 \\ \text { Variance } & 0.01715645 \\ \text { Skewness } & 0.770266382 \\ \text { Kurtosis } & 3.03446386 \\ \text { Coeff. of Variability } & 0.876897857 \\ \text { Range Minimum } & 4.62405 \mathrm{E}-08 \\ \text { Range Maximum } & 0.768202815 \\ \text { Range Width } & 0.768202769 \\ \text { Mean Std. Error } & 0.001127319\end{array}$

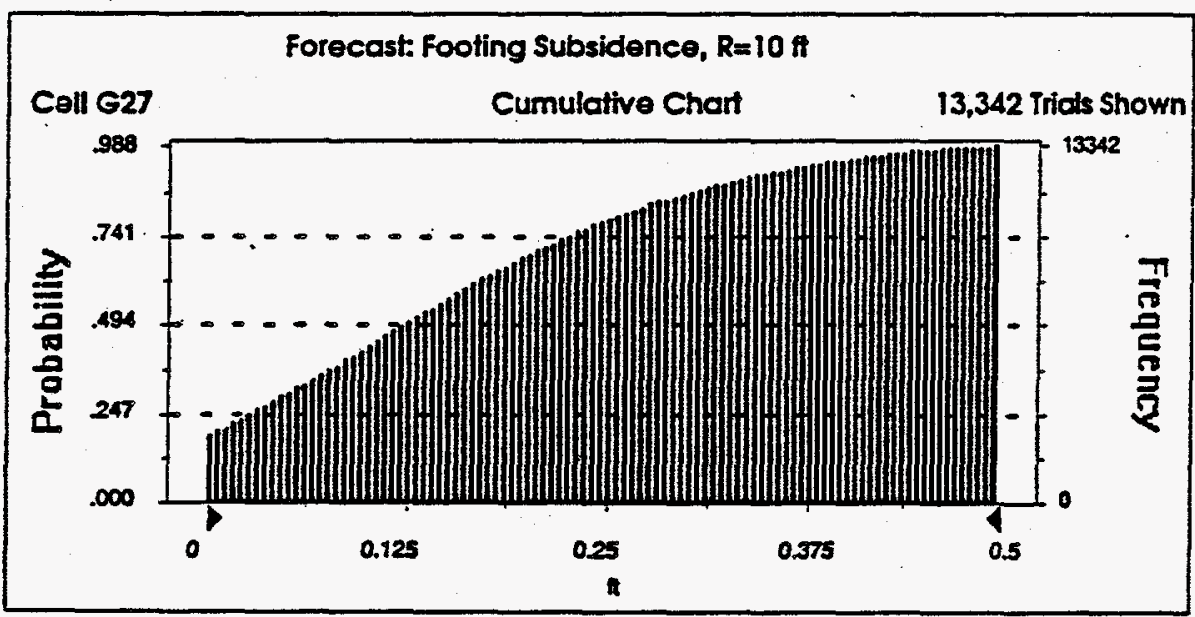


Forecast: Footing Subsidence, $R=10$ ff (cont'd)

Cell: $\mathbf{G 2 7}$

Percentiles:

\begin{tabular}{r} 
Percentile \\
\hline $0 \%$ \\
$5 \%$ \\
$25 \%$ \\
$50 \%$ \\
$75 \%$ \\
$95 \%$ \\
$100 \%$
\end{tabular}

ft (aporox.) 4.62405E-08 0.000674434 0.031044942

0.129297108

0.23393608

0.397258007

0.768202815

End of Forecast

B. 16 
Summary:

Display Range is from 0 to $1 \mathrm{ft}$

Entire Range is from 0.000000036208293143 to $1.200189041121692 \mathrm{ft}$

- After 13,500 Trials, the Std. Error of the Mean is 0.001755849394228685

Statistics:

Trials

Value

13500

Mean

0.384779742

Median (approx.)

0.374986924

Mode (approx.)

0.006000981

Standard Deviation

0.204011264

Variance

0.041620596

Skewness

0.308604159

Kurtosis

2.794243673

Coeff. of Variability

0.530202714

Range Minimum

3.62083E-08

Range Maximum

1.200189041

Range Width

1.200189005

Mean Std. Error

0.001755849

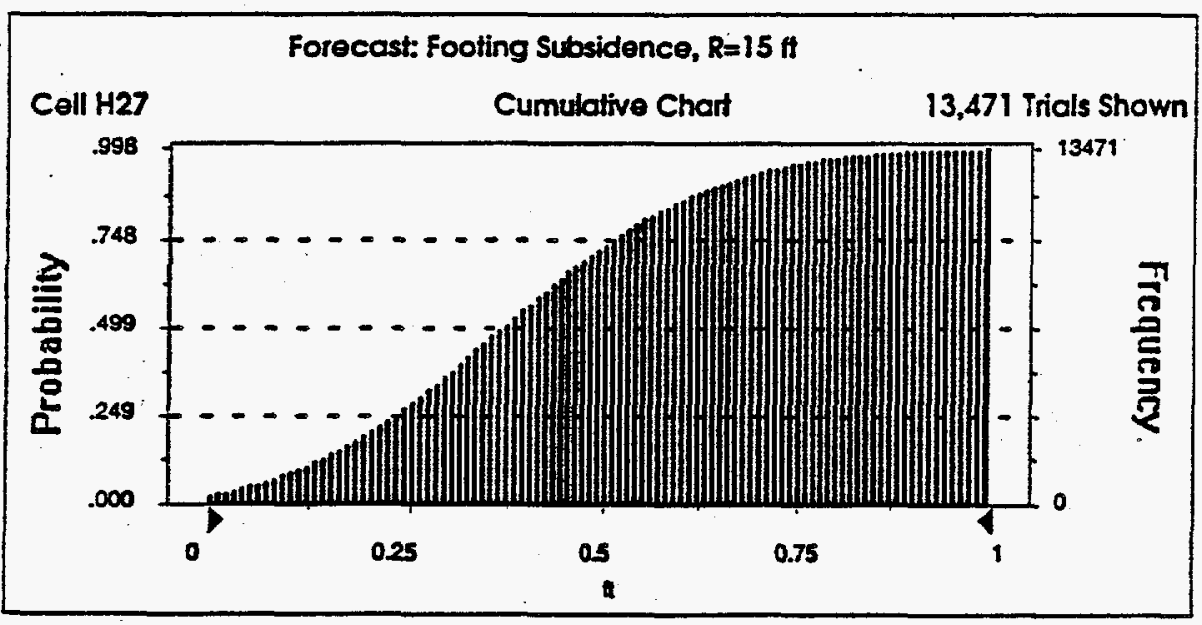


Forecast: Footing Subsidence, $R=15$ ft (cont'd)

Percentiles:

\begin{tabular}{r} 
Percentile \\
\hline $0 \%$ \\
$5 \%$ \\
$25 \%$ \\
$50 \%$ \\
$75 \%$ \\
$95 \%$ \\
$100 \%$
\end{tabular}

ft (approx.)

3.62083E-08

0.056542274

0.237340783

0.374986924

0.520487799

0.737793643

1.200189041

End of Forecast 
Summary:

Display Range is from 0.075 to 0.25

Entire Range is from 0.070967095040170569 to 0.24159833608565162

After 13.500 Trials, the Std. Error of the Mean is 0.000236249199190257

$\begin{array}{lr}\text { Statistics: } & \frac{\text { Value }}{13500} \\ \text { Trials } & 0.16468121 \\ \text { Mean } & 0.167472187 \\ \text { Median (approx.) } & 0.170786371 \\ \text { Mode (approx.) } & 0.027449676 \\ \text { Standard Deviation } & 0.000753485 \\ \text { Variance } & -0.330193059 \\ \text { Skewness } & 2.636078232 \\ \text { Kurtosis } & 0.166683718 \\ \text { Coeff. of Variability } & 0.070967095 \\ \text { Range Minimum } & 0.241598336 \\ \text { Range Maximum } & 0.170631241 \\ \text { Range Width } & 0.000236249 \\ \text { Mean Std. Error } & \end{array}$

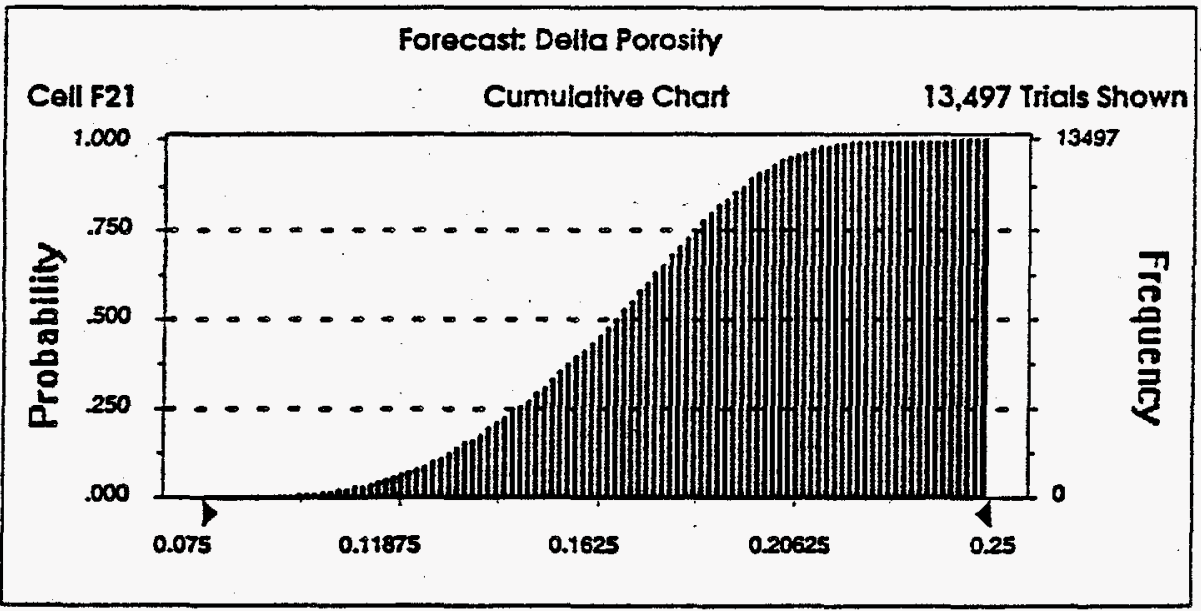


Forecast: Delta Porosity (cont'd)

Cell: F21

Percentiles:

\begin{tabular}{r} 
Percentile \\
\hline $0 \%$ \\
$5 \%$ \\
$25 \%$ \\
$50 \%$ \\
$75 \%$ \\
$95 \%$ \\
$100 \%$
\end{tabular}

Value (approx.)

0.070967095

0.116082808

0.145697795

0.167472187

0.185090664

0.205752849

0.241598336

End of Forecast 
Summary:

Display. Range is from 120 to 132

Entire Range is from 119.055440996836623 to 132.668151340263819

After 13,500 Trials, the Std. Error of the Mean is 0.018775710800563678

\section{Statistics: \\ Trials \\ Mean \\ Median (approx.) \\ Mode (approx.) \\ Standard Deviation \\ Variance \\ Skewness \\ Kurtosis \\ Coeff. of Variability \\ Range Minimum \\ Range Maximum \\ Range Width \\ Mean Std. Error}

\begin{abstract}
Value
13500

125.9751723

125.9875902

126.0659868

2.181540457

4.759118767

0.005701619

2.619062263

0.017317225

119.055441

132.6681513

13.61271034

0.018775711
\end{abstract}

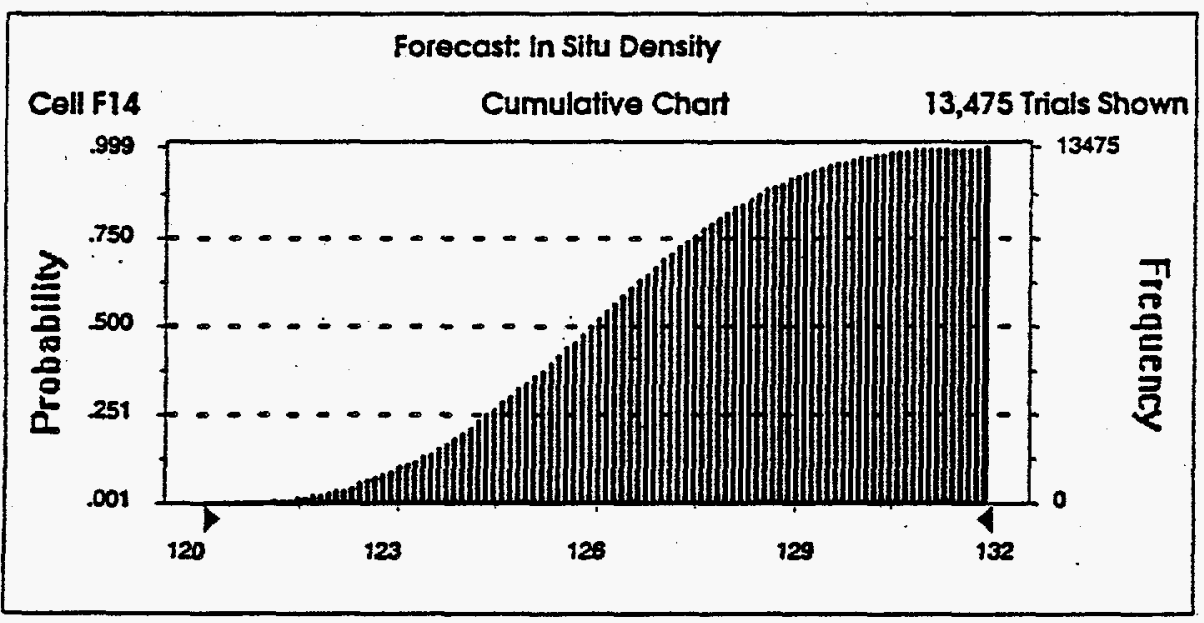


Forecast: In Siłu Density (cont'd)

Percentiles:

\begin{tabular}{r} 
Percentile \\
\hline $0 \%$ \\
$5 \%$ \\
$25 \%$ \\
$50 \%$ \\
$75 \%$ \\
$95 \%$ \\
$100 \%$
\end{tabular}

\section{Cell: Fi4}

Value (approx.)

119.055441

122.3784197

124.4357818

125.9875902

127.5164264

129.6171756

132.6681513

End of Forecast 
Summary:

Display Range is from 0 to $0.00035 \mathrm{ft}$

Entire Range is from 0.000000039768765966 to $0.011504095756045938 \mathrm{ft}$

After 13.500 Trials, the Std. Error of the Mean is 0.00000114791228453

Statistics:

Trials

Mean

Median (approx.)

Mode (approx.)

Standard Deviation

Variance

Skewness

Kurtosis

Coeff. of Variability

Range Minimum

Range Maximum

Range Width

Mean Std. Error
Value

13500

1.86026E-06

$1.92175 \mathrm{E}-05$

5.756E-05

0.000133375

1.7789E-08

80.90988053

6639.33845

71.69697231

$3.97688 E-08$

0.011504096

0.011504056

$1.14791 E-06$

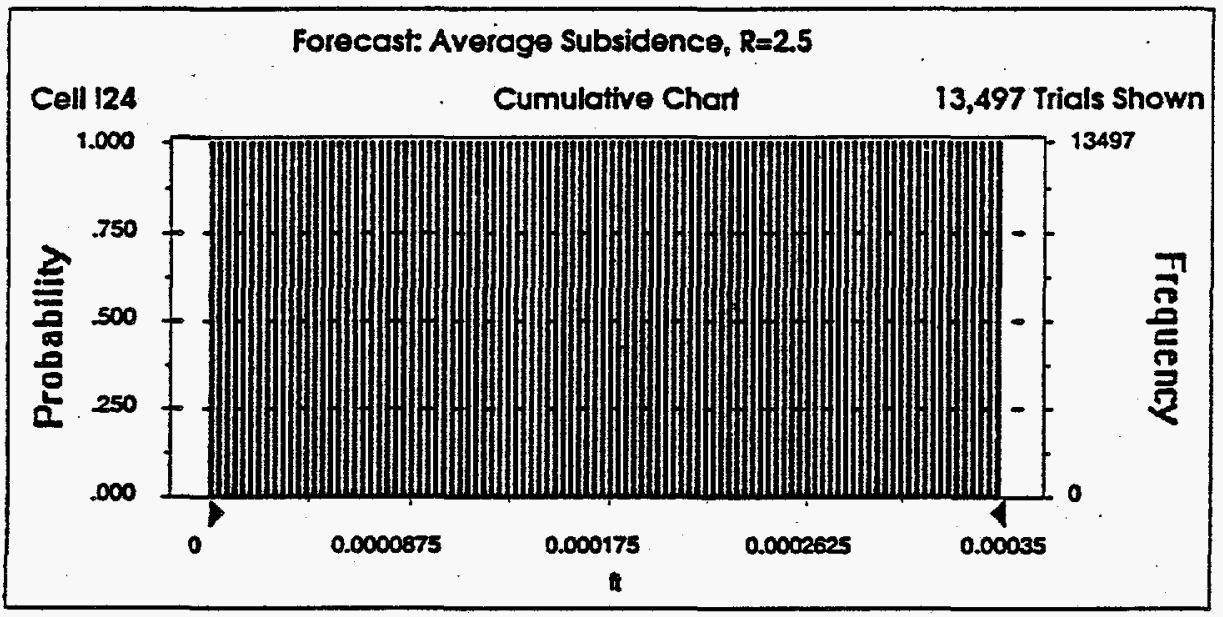

B. 23 
Forecast. Average Subsidence, $R=2.5$ (cont'd)

Percentiles:

\begin{tabular}{r} 
Percentile \\
\hline $0 \%$ \\
$5 \%$ \\
$25 \%$ \\
$50 \%$ \\
$75 \%$ \\
$95 \%$ \\
$100 \%$
\end{tabular}

At (approx.)

3.97688E-08

$1.95754 E-06$

9.62861E-06

1.92175E-05

2.88063E-05

3.64774E-05

0.011504096

End of Forecast 
Summary:

Display Range is from 0 to $0.0007 \mathrm{ft}$

Entire Range is from 0.000000079537531932 to $0.023008191512091877 \mathrm{ft}$ After 13,500 Trials, the Std. Error of the Mean is 0.000002295824569061

Statistics:

Trials

Mean

Value

Median (approx.)

Mode (approx.)

13500

Standard Deviation

Variance

Skewness

Kurtosis

Coeff. of Variability

Range Minimum

Range Maximum

$3.72053 E-06$

3.84349E-05

0.00011512

0.000266751

$7.11559 E-08$

80.90988053

6639.33845

71.69697231

$7.95375 E-08$

0.023008192

Range Width

0.023008112

Mean Std. Error

2.29582E-06

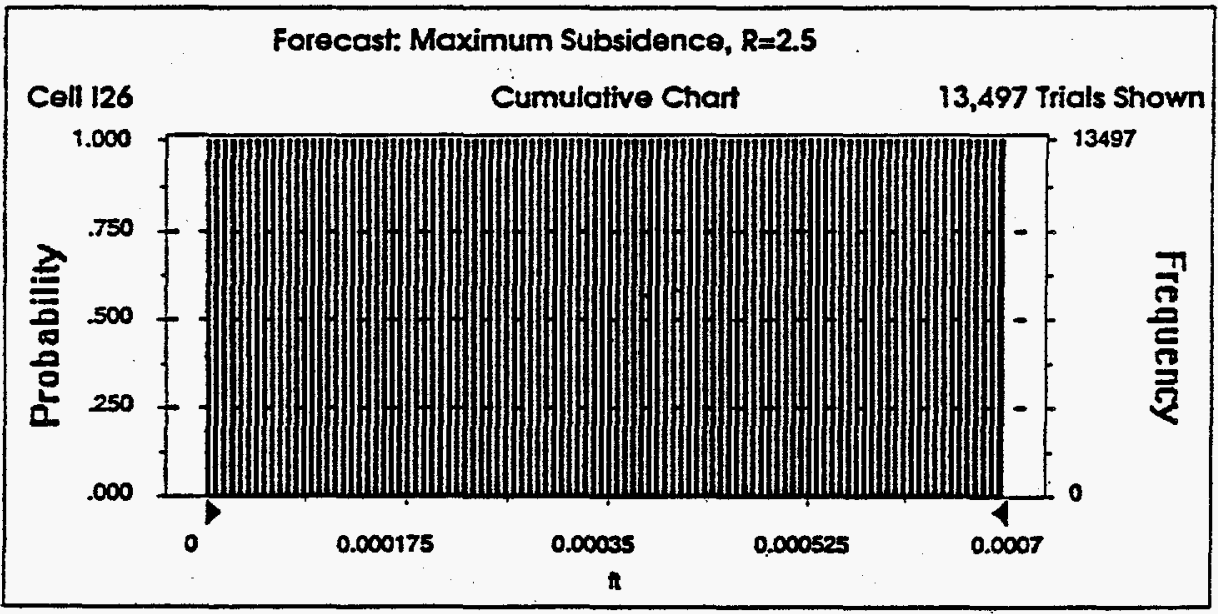


Forecast: Maximum Subsidence, $R=2.5$ (cont'd)

Percentiles:

\begin{tabular}{r} 
Percentile \\
\hline $0 \%$ \\
$5 \%$ \\
$25 \%$ \\
$50 \%$ \\
$75 \%$ \\
$95 \%$ \\
$100 \%$
\end{tabular}

ff(approx.)

7.95375E-08

$3.91508 E-06$

1.92572E-05

3.84349E-05

5.76126E-05

$7.29548 E-05$

0.023008192

End of Forecast

B. 26 
Summary:

Display Range is from 0 to $0.00035 \mathrm{ft}$

Entire Range is from 0.00000007037165064 to $0.011161343911771492 \mathrm{ft}$

After 13,500 Trials, the Std. Error of the Mean is 0.000001128213047942

Statistics:

Trials

Volue

Mean

13500

Median (approx.)

$1.88364 \mathrm{E}-06$

Mode (approx.)

$1.86766 \mathrm{E}-05$

Standard Deviation

5.58767E-05

Variance

0.000131087

Skewness

$1.71837 \mathrm{E}-08$

Kuntosis

80.42672349

Coeff. of Variability

6562.759049

Range Minimum

69.59211009

Range Maximum

7.03717E-08

Range Width

0.011161344

Mean Std. Error

0.011161274

$1.12821 E-06$

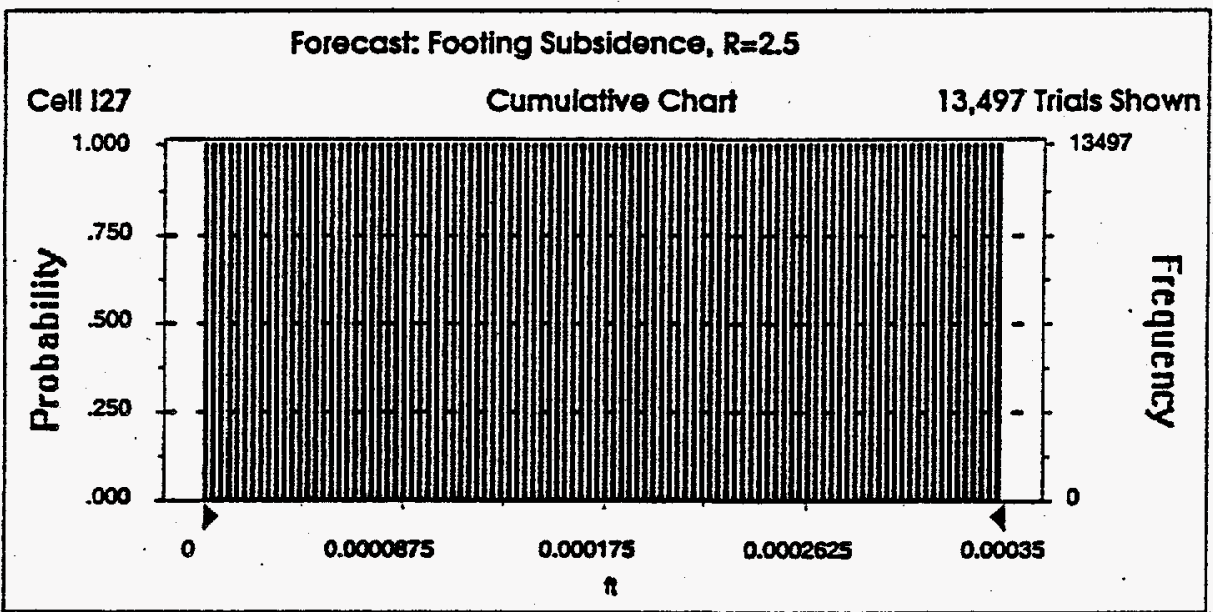


Forecast: Footing Subsidence, $R=2.5$ (cont'd)

Percentiles:

\begin{tabular}{r} 
Percentile \\
\hline $0 \%$ \\
$5 \%$ \\
$25 \%$ \\
$50 \%$ \\
$75 \%$ \\
$95 \%$ \\
$100 \%$
\end{tabular}

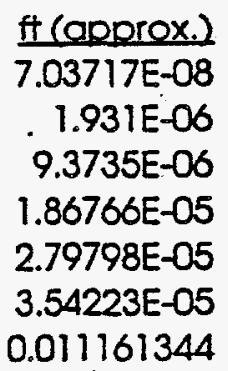

End of Forecast 
Summary:

Display Range is from 0 to $0.045 \mathrm{ft}$

Entire Range is from 0.000000033387247316 to $0.1498029515393173 \mathrm{ft}$

After 13.500 Trials, the Std. Error of the Mean is 0.00011998164651324

Statistics:

Trials

Value

Mean

13500

Median (approx.)

Mode (approx.)

0.004096484

Standard Deviation

0.000288609

Variance

0.000749048

Skewness

0.013940608

Kurtosis

0.000194341

Coeff. of Variability

4.409392747

Range Minimum

25.31464429

3.403066532

Range Maximum

$3.33872 E-08$

Range Width

0.149802952

Mean Std. Error

0.149802918

0.000119982

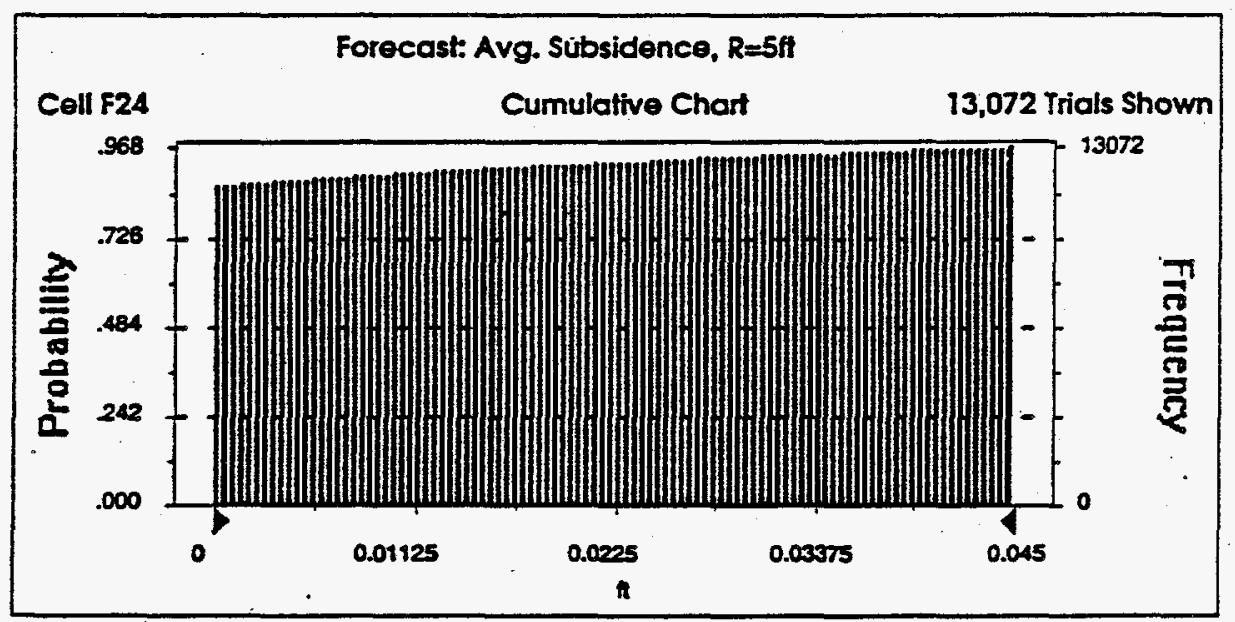


Percentiles:

Percentile

$0 \%$

$10 \%$

$25 \%$

$50 \%$

$75 \%$

$90 \%$

$100 \%$
\# (approx.)

3.33872E-08

$5.77486 E-05$

0.000144321

0.000288609

0.000432897

0.010890468

0.149802952

End of Forecast 
Summary:

Display Range is from 0 to $0.35 \mathrm{ft}$

Entire Range is from 0.00000002496755177 to $0.50431966435092768 \mathrm{ft}$

After 13.500 Trials, the Std. Error of the Mean is 0.000698864041943592

Statistics:

Trials

Value

Mean

13500

Median (approx.)

0.089934427

Mode (approx.)

0.075398308

Standard Deviation

0.002521623

Variance

0.081200664

Skewness

0.006593548

Kurtosis

0.892427659

Coeff. of Variability

3.383018188

0.902887431

Range Minimum

$2.49676 E-08$

Range Maximum

0.504319664

Range Width

0.504319639

Mean Std. Error

0.000698864

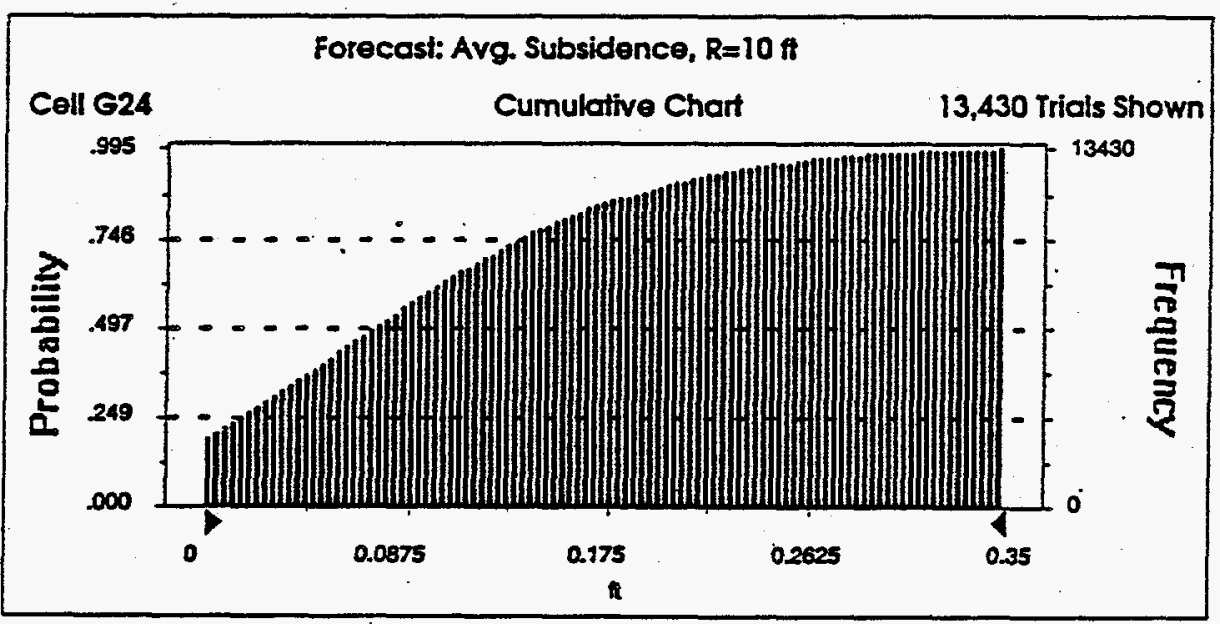


Forecast: Avg. Subsidence, $R=10 \mathrm{tt}$ (cont'd)

Cell: $\mathbf{6 2 4}$

Percentiles:

Percentile

$0 \%$

$10 \%$

$25 \%$

$50 \%$

$75 \%$

$90 \%$

$100 \%$
At (aporox.)

2.49676E-08

0.000883075

0.017729039

0.075398308

0.140196279

0.205362617

0.504319664

End of Forecast 
Summary:

Display Range is from 0 to $0.55 \mathrm{ft}$

Entire Range is from 0.00000001920699933 to $0.70054127909439556 \mathrm{ft}$

After 13,500 Trials, the Std. Error of the Mean is 0.001016717064956812

Statistics:

Trials

Mean

Median (approx.)

Mode (approx.)

Standard Deviation

Variance

Skewness

Kuntosis

Coeff. of Variability

Range Minimum

Range Maximum

Range Width

Mean Std. Error
Value

13500

0.216711248

0.208784666

0.003502726

0.118131848

0.013955133

0.393813862

2.896721457

0.54511175

1.9207E-08

0.700541279

0.70054126

0.001016717

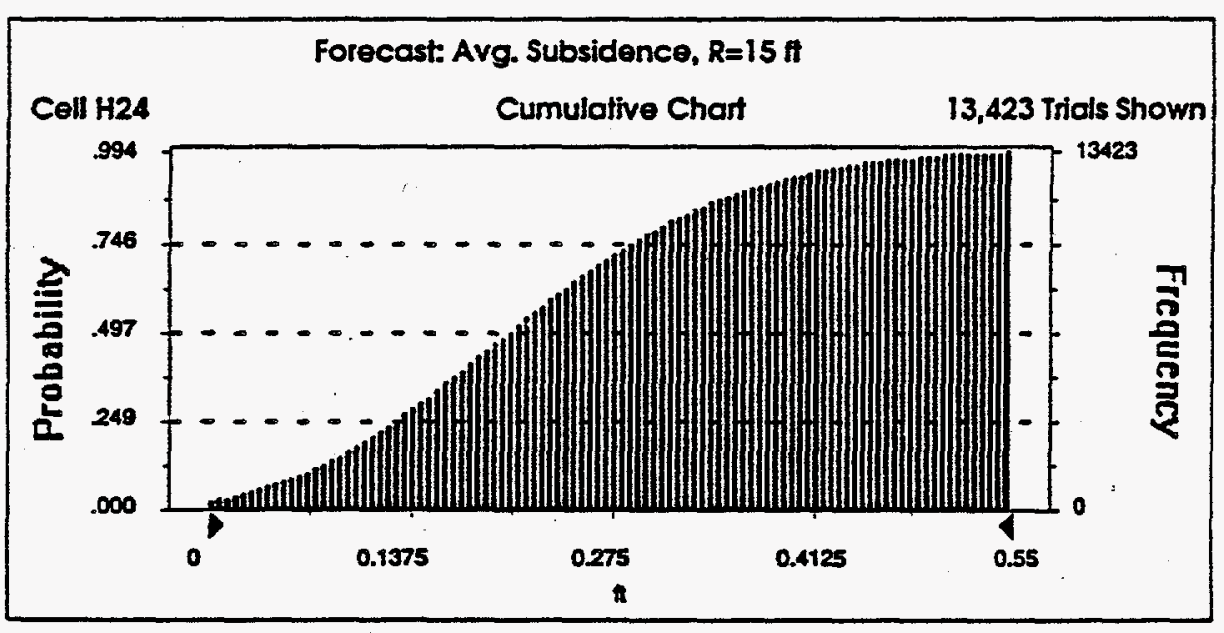


Forecast. Avg. Subsidence, $R=15 \mathrm{ft}$ (cont'd)

Cell: $\mathrm{H} 24$

Percentiles:

\begin{tabular}{r} 
Percentile \\
\hline $0 \%$ \\
$10 \%$ \\
$25 \%$ \\
$50 \%$ \\
$75 \%$ \\
$90 \%$ \\
$100 \%$
\end{tabular}
ft (approx.)
1.9207E-08
$0: 067008314$
0.131069915
0.208784666
0.29349544
0.375049053
0.700541279

End of Forecast

B.34 
Summary: .

Display Range is from 0 to $0.09 \mathrm{ft}$

Entire Range is from 0.000000066774494632 to $0.29960590307863461 \mathrm{ft}$ After 13,500 Trials, the Std. Error of the Mean is 0.00023996329302648

Stotistics:

Trials

Value

Mean

13500

Median (approx.)

0.008192968

Mode (approx.)

0.000577218

Standard Deviation

0.001498096

0.027881215

Variance

0.000777362

Skewness

4.409392747

Kurtosis

25.31464429

Coeff. of Variability

3.403066532

Range Minimum

$6.67745 E-08$

Range Maximum

0.299605903

Range Width

0.299605836

Mean Std. Error

0.000239963

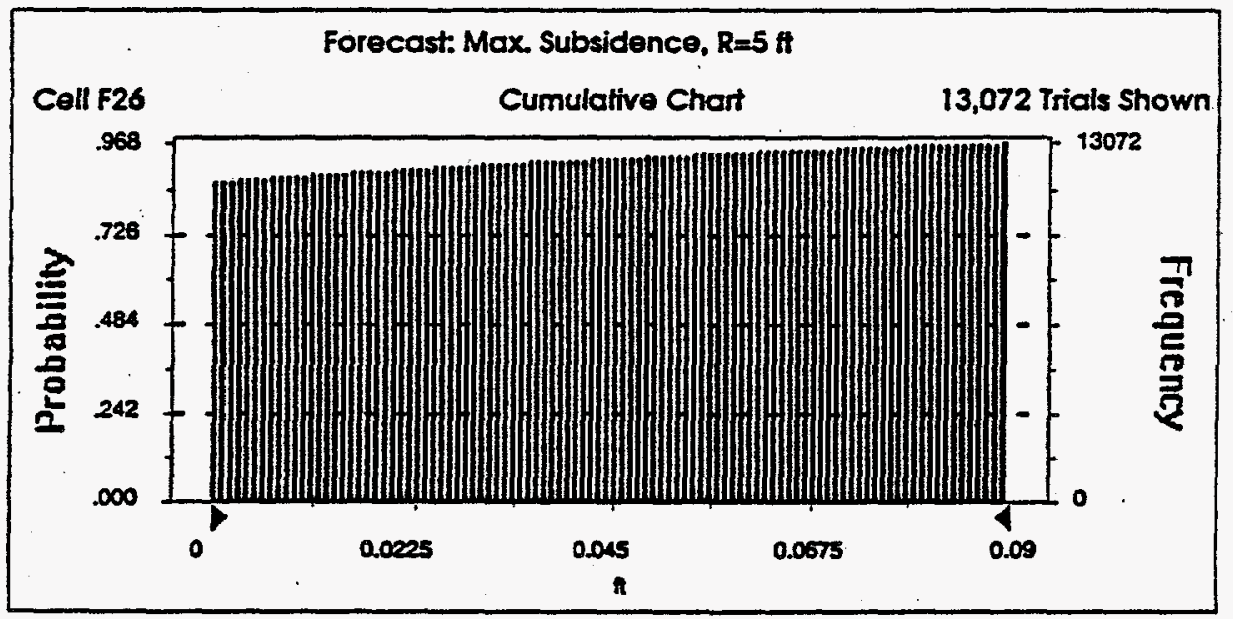


Percentiles:

\begin{tabular}{r} 
Percentile \\
\hline $0 \%$ \\
$10 \%$ \\
$25 \%$ \\
$50 \%$ \\
$75 \%$ \\
$90 \%$ \\
$100 \%$
\end{tabular}

\author{
ft (approx.) \\ 6.67745E-08 \\ 0.000115497 \\ 0.000288643 \\ 0.000577218 \\ 0.000865794 \\ 0.021780936 \\ 0.299605903
}

End of Forecast 
Summary:

Display Range is from 0 to $0.7 \mathrm{ft}$

Entire Range is from 0.000000049935103541 to $1.00863932870185535 \mathrm{ft}$

After 13,500 Trials, the Std. Error of the Mean is 0.001397728083887184

Statistics:

Trials

Value

Mean

13500

Median (approx.)

0.179868854

Mode (approx.)

0.150796615

Standard Deviation

Variance

0.162401328

Skewness

0.026374191

Kurtosis

0.892427659

Coeff. of Variability

3.383018188

0.902887431

Range Minimum

4.99351E-08

Range Maximum

1.008639329

Range Width

1.008639279

Mean Std. Error

0.001397728

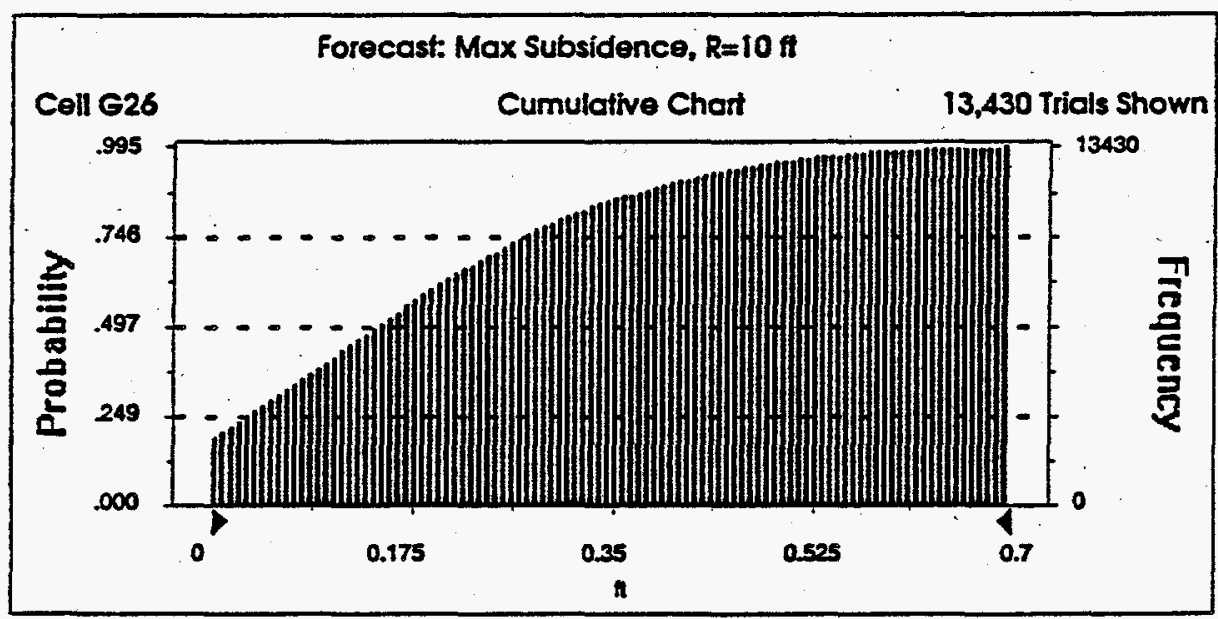


Forecast: Max Subsidence, $R=10$ ft (cont'd)

Cell: $\mathbf{6 2 6}$

Percentiles:

\begin{tabular}{r} 
Percentile \\
\hline $0 \%$ \\
$10 \%$ \\
$25 \%$ \\
$50 \%$ \\
$75 \%$ \\
$90 \%$ \\
$100 \%$
\end{tabular}

At (approx.)

4.99351E-08

0.00176615

0.035458079

0.150796615

0.280392558

0.410725234

1.008639329

End of Forecast 
Summary:

Display Range is from 0 to $1.1 \mathrm{ft}$

Entire Range is from 0.000000038413998659 to $1.40108255818879113 \mathrm{ft}$

After 13,500 Trials, the Std. Error of the Mean is 0.002033434129913625
Statistics:
Trials
Mean
Median (approx.)
Mode (approx.)
Standard Deviation
Variance
Skewness
Kurtosis
Coeff. of Variability
Range Minimum
Range Maximum
Range Width
Mean Std. Error

Value

13500

0.433422497

0.417569332

0.007005451

0.236263696

0.055820534

0.393813862

2.896721457

0.54511175

3.8414E-08

1.401082558

1.40108252

0.002033434

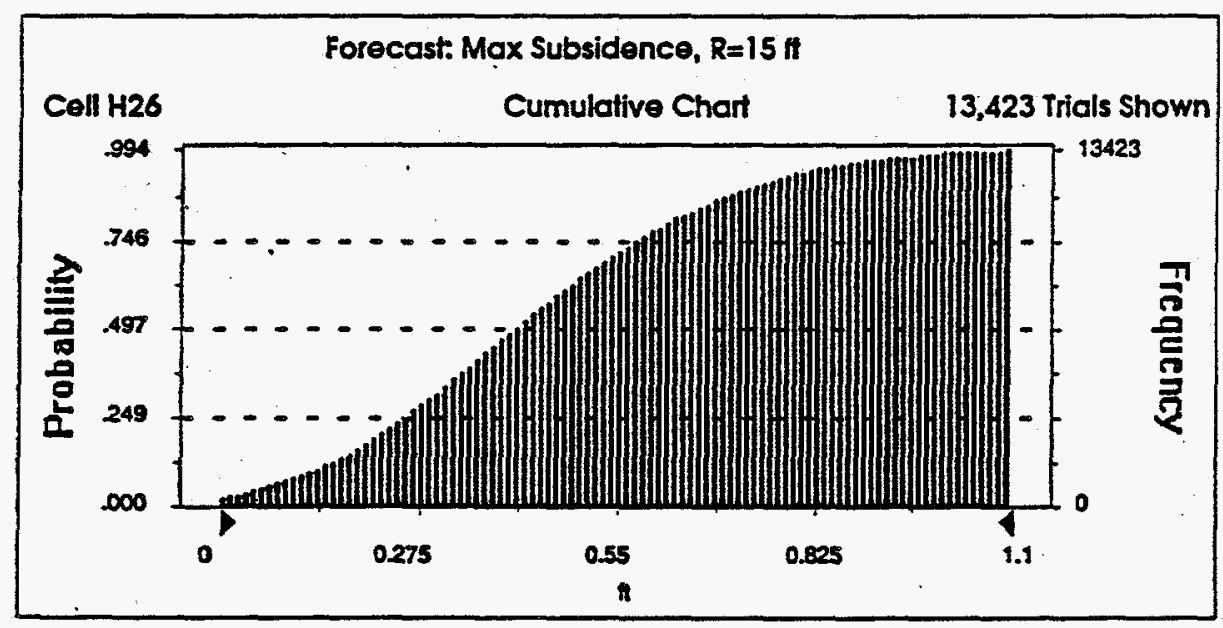


Forecast: Max Subsidence, $R=15$ ft (contd)

Cell: $\mathrm{H} 26$

Percentiles:

\begin{tabular}{r} 
Percentile \\
\hline $0 \%$ \\
$10 \%$ \\
$25 \%$ \\
$50 \%$ \\
$75 \%$ \\
$90 \%$ \\
$100 \%$
\end{tabular}

ft (aporox.)

3.8414E-08

0.134016627

0.262139831

0.417569332

0.586990879

0.750098106

1.401082558

End of Forecast

B. 40 
Summary:

Display Range is from 0 to $0.055 \mathrm{ft}$

Entire Range is from 0.000000060251643046 to $0.18124377384150667 \mathrm{ft}$ After 13,500 Trials, the Std. Error of the Mean is 0.000162029820129344

Statistics:

Trials

Value

13500

Mean

0.005643829

Median (approx.)

0.000349382

Mode (approx.)

0.000906279

Standard Deviation

0.018826164

Variance

0.000354424

Skewness

4.194770629

Kuntosis

22.69547018

Coeff. of Variability

3.335707838

Range Minimum

$6.02516 E-08$

Range Maximum

0.181243774

Range Width

0.181243714

Mean Std. Error

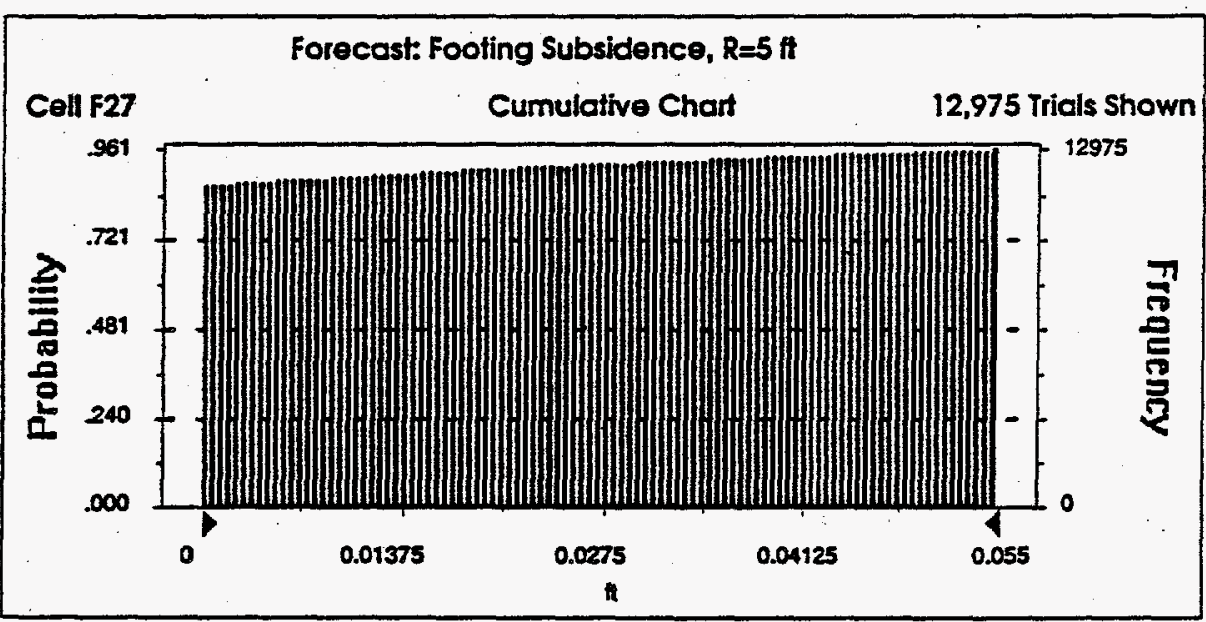


Forecast: Footing Subsidence, $R=5 \mathrm{ft}$ (cont'd)

Percentiles:

\begin{tabular}{r} 
Percentile \\
\hline $0 \%$ \\
$10 \%$ \\
$25 \%$ \\
$50 \%$ \\
$75 \%$ \\
$90 \%$ \\
$100 \%$
\end{tabular}
$\mathrm{ft}$ (approx.)
$6.02516 \mathrm{E}-08$
$0.99246 \mathrm{E}-05$
0.000174721
0.000349382
0.000524043
0.015736618
0.181243774

End of Forecast 
Summary:

Display Range is from 0 to $0.5 \mathrm{ft}$

Entire Range is from 0.000000046240457277 to $0.76820281545647207 \mathrm{ft}$

After 13,500 Trials, the Std. Error of the Mean is 0.001127318996269674

Statistics:

Trials

Value

Mean

13500

Median (approx.)

0.149370454

Mode (approx.)

0.129297108

Standard Deviation

0.00384106

Variance

0.130982631

Skewness

0.01715645

Kurtosis

Coeff. of Variability

0.770266382

3.03446386

Range Minimum

0.876897857

Range Maximum

4.62405E-08

Range Width

0.768202815

Mean Std. Error

0.768202769

0.001127319

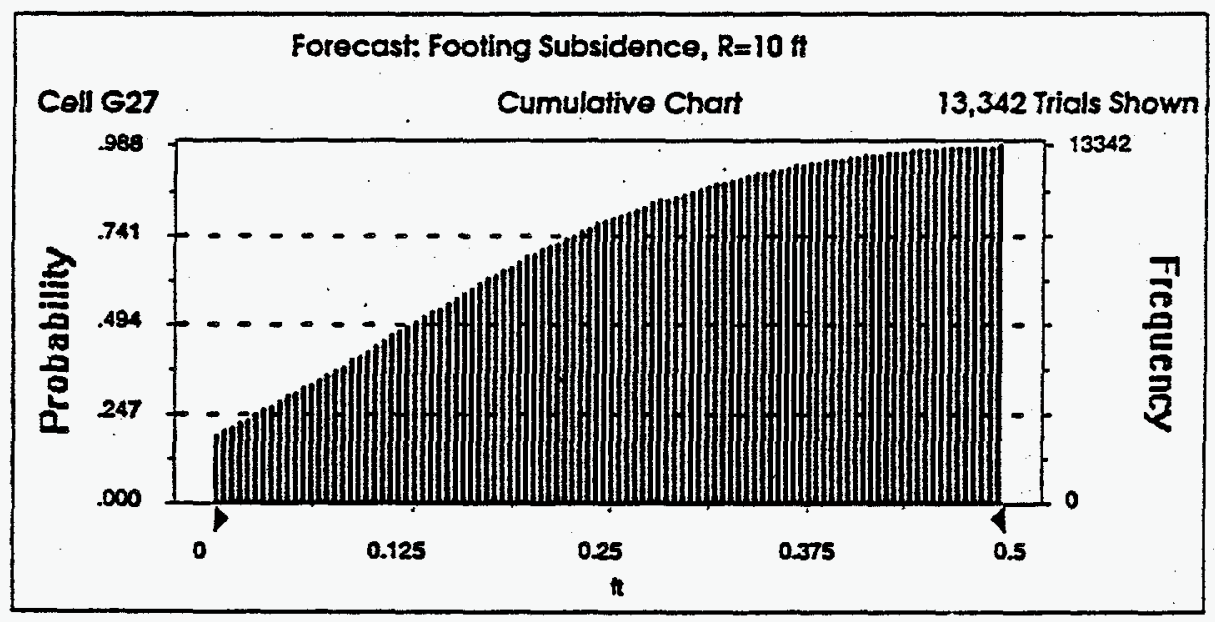


Percentiles:

Percentile
$0 \%$
$10 \%$
$25 \%$
$50 \%$
$75 \%$
$90 \%$
$100 \%$

At (approx.)

4.62405E-08

0.001348822

0.031044942

0.129297108

0.23393608

0.336071456

0.768202815

End of Forecost 
Summary:

Display Range is from 0 to $1 \mathrm{ft}$

Entire Range is from 0.000000036208293143 to $1.200189041121692 \mathrm{ft}$

After 13,500 Trials, the Std. Error of the Mean is 0.001755849394228685

Statistics:

Trials

$\underline{\text { Volue }}$

Mean

13500

Median (approx.)

0.384779742

Mode (approx.)

0.374986924

Standard Deviation

0.006000981

Variance

0.204011264

Skewness

0.041620596

Kurtosis

0.308604159

Coeff. of Variability

2.794243673

Range Minimum

0.530202714

Range Maximum

3.62083E-08

Range Width

1.200189041

Mean Std. Error

1.200189005

0.001755849

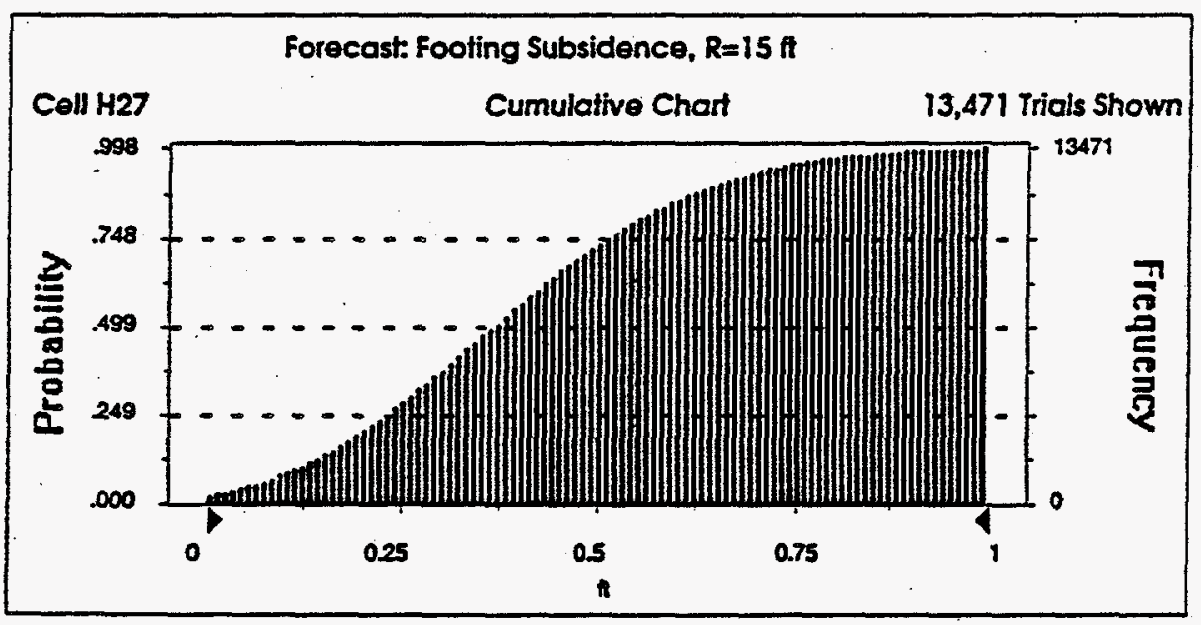


Forecast: Footing Subsidence, $R=15 \mathrm{ft}$ (cont'd)

Percentiles:

\begin{tabular}{r} 
Percentile \\
\hline $0 \%$ \\
$10 \%$ \\
$25 \%$ \\
$50 \%$ \\
$75 \%$ \\
$90 \%$ \\
$100 \%$
\end{tabular}

ft (approx.)

3.62083E-08

0.121859227

0.237340783

0.374986924

0.520487799

0.656933678

1.200189041

End of Forecast 
Summary:

Display Range is from 0.075 to 0.25

Entire Range is from 0.070967095040170569 to 0.24159833608565162

After 13,500 Trials, the Std. Error of the Mean is 0.000236249199190257

Statistics:

Trials

$\underline{V a l u e}$

13500

Mean

0.16468121

Median (approx.)

0.167472187

Mode (approx.)

0.170786371

Standard Deviation

0.027449676

Variance

0.000753485

Skewness

$-0.330193059$

Kurtosis

2.636078232

Coeff. of Variability

0.166683718

Range Minimum

0.070967095

Range Maximum

0.241598336

Range Width

0.170631241

Mean Std. Error

0.000236249

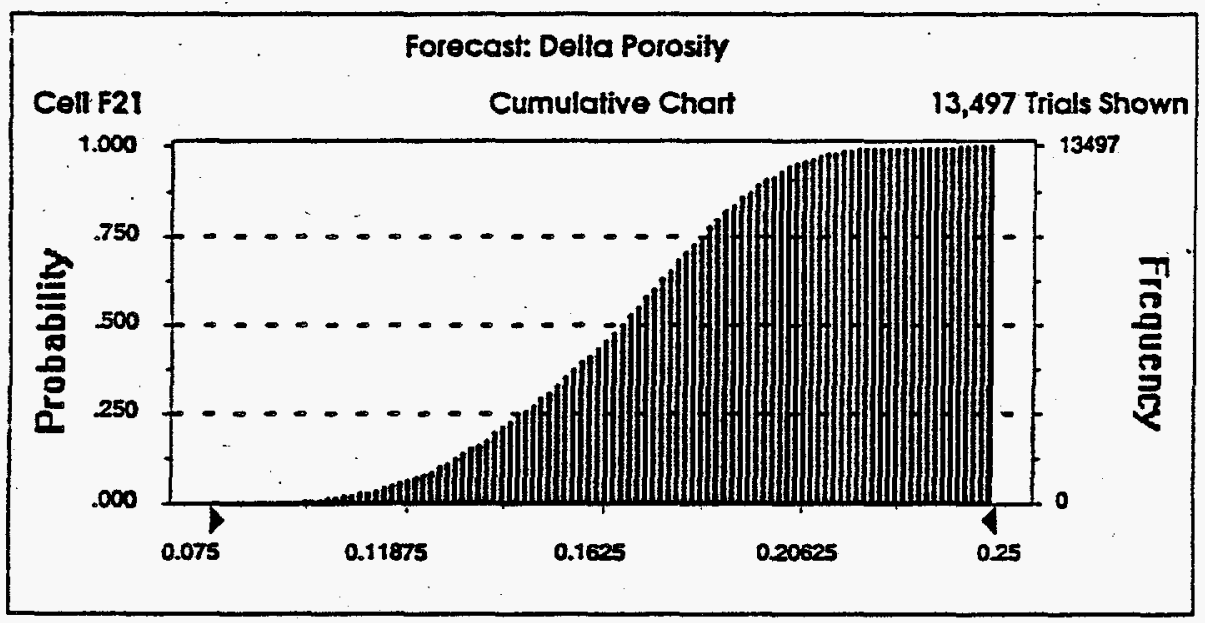


Percentiles:

\begin{tabular}{r} 
Percentile \\
\hline $0 \%$ \\
$10 \%$ \\
$25 \%$ \\
$50 \%$ \\
$75 \%$ \\
$90 \%$ \\
$100 \%$
\end{tabular}

Value (approx.) 0.070967095

0.126825679

0.145697795

0.167472187

0.185090664

0.198542386

0.241598336

End of Forecost 
Summary:

Display Range is from 120 to 132

Entire Range is from 119.055440996836623 to 132.668151340263819

After 13,500 Trials, the Std. Error of the Mean is 0.018775710800563678

Statistics:

Trials

Mean

Value

13500

Median (approx.)

125.9751723

Mode (approx.)

125.9875902

Standard Deviation

126.0659868

Variance

2.181540457

Skewness

4.759118767

0.005701619

Kurtosis

2.619062263

Coeff. of Voriability

0.017317225

Range Minimum

119.055441

Range Maximum

132.6681513

Range Width

13.61271034

Mean Std. Error

0.018775711

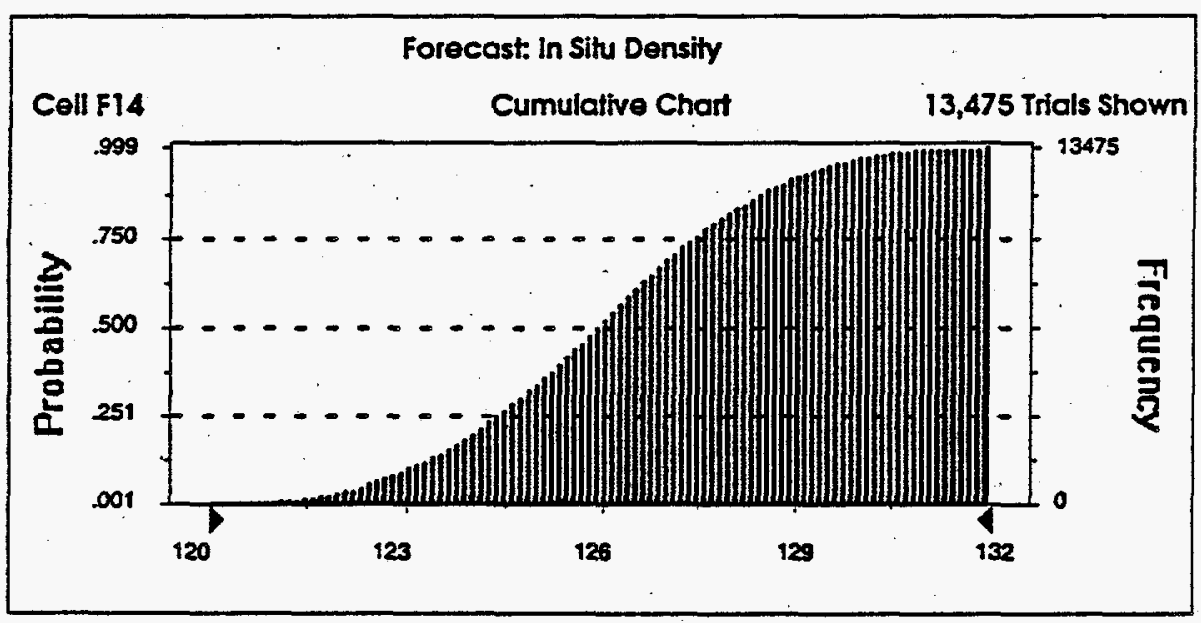


Forecast: In Situ Density (conf'd)

Percentiles:

\begin{tabular}{r} 
Percentile \\
\hline $0 \%$ \\
$10 \%$ \\
$25 \%$ \\
$50 \%$ \\
$75 \%$ \\
$90 \%$ \\
$100 \%$
\end{tabular}

Cell: Fid

\author{
Value (approx.) \\ 119.055441 \\ $123.0792934^{\circ}$ \\ 124.4357818 \\ 125.9875902 \\ 127.5164264 \\ 128.8339046 \\ 132.6681513
}

End of Forecast 


\title{
Summary:
}

Display Range is from 0 to $0.00035 \mathrm{ft}$

Entire Range is from 0.000000039768765966 to 0.011504095756045938 it

After 13,500 Trials, the Std. Error of the Mean is 0.00000114791228453

\author{
Statistics: \\ Trials \\ Mean \\ Median (approx.) \\ Mode (approx.) \\ Standard Deviation \\ Variance \\ Skewness \\ Kurtosis \\ Coeff. of Variability \\ Range Minimum \\ Range Maximum \\ Range Width \\ Mean Std. Error
}

Value

13500

1.86026E-06

$1.92175 E-05$

5.756E-05

0.000133375

1.7789E-08

80.90988053

6639.33845

71.69697231

$3.97688 \mathrm{E}-08$

0.011504096

0.011504056

1.14791E-06

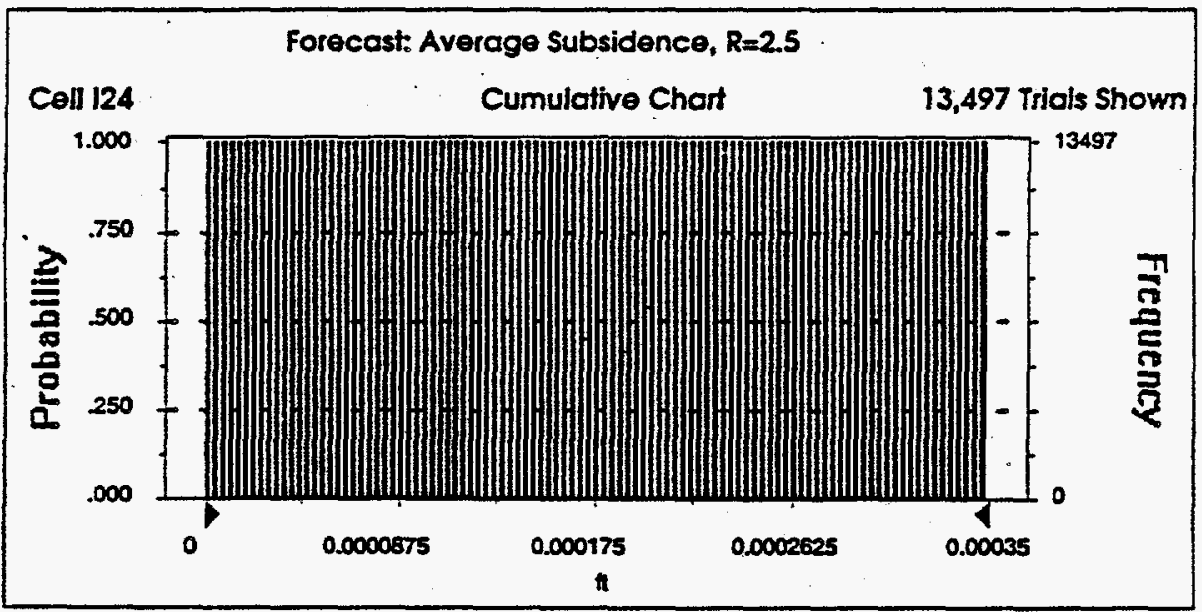


Forecast: Average Subsidence, $R=2.5$ (cont'd)

Cell: 124

Percentiles:

\begin{tabular}{r} 
Percentile \\
\hline $0 \%$ \\
$10 \%$ \\
$25 \%$ \\
$50 \%$ \\
$75 \%$ \\
$90 \%$ \\
$100 \%$
\end{tabular}

It (aporox.)

3.97688E-08

3.87531E-06

9.62861E-06

$1.92175 E-05$

2.88063E-05

3.45596E-05

0.011504096

End of Forecast 
Summary:

Display Range is from 0 to $0.0007 \mathrm{ft}$

Entire Range is from 0.000000079537531932 to $0.023008191512091877 \mathrm{ft}$

After 13.500 Trials, the Std. Error of the Mean is 0.000002295824569061

Statistics:

Trials

$\underline{\text { Value }}$

13500

Mean

3.72053E-06

Median (approx.)

$3.84349 E-05$

Mode (approx.)

0.00011512

Standard Deviation

0.000266751

Variance

7.11559E-08

Skewness

80.90988053

Kurtosis

6639.33845

Coeff. of Voriability

71.69697231

Range Minimum

$7.95375 E-08$

Range Maximum

0.023008192

Range Width

0.023008112

Mean Std. Error

2.29582E-06

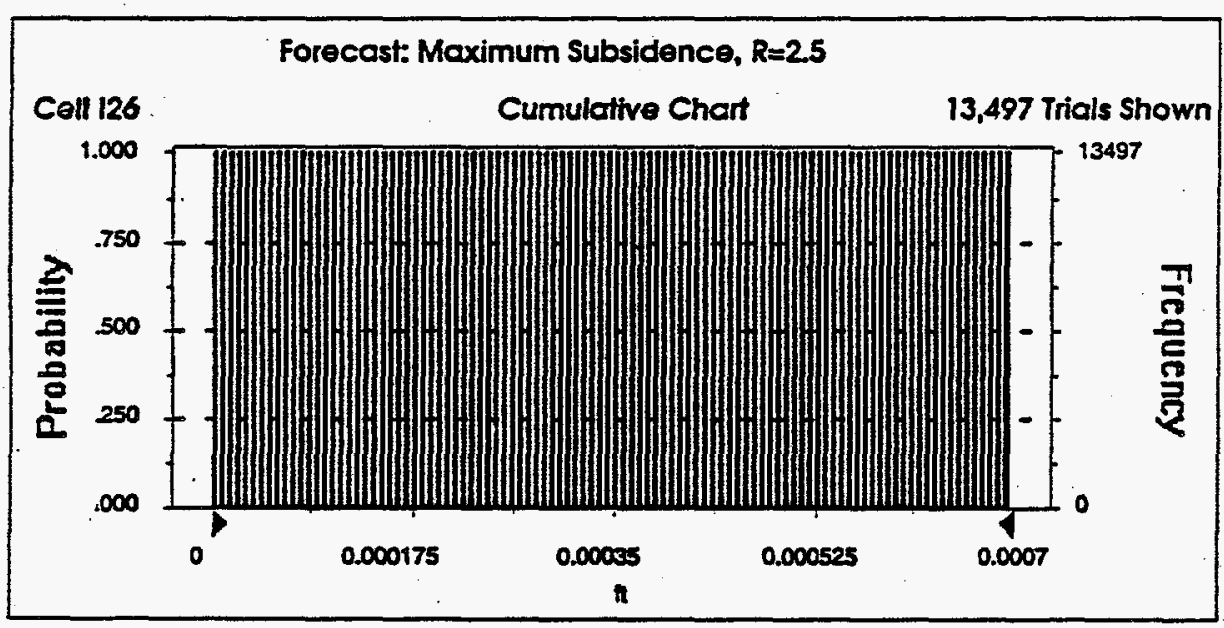

B. 53 
Forecast: Maximum Subsidence, $R=2.5$ (cont'd)

Cell: 126

Percentiles:

Percentile

$0 \%$

$10 \%$

$25 \%$

$50 \%$

$75 \%$

$90 \%$

$100 \%$
At (aporox.)

7.95375E-08

$7.75061 E-06$

$1.92572 E-05$

3.84349E-05

$5.76126 E-05$

$6.91192 E-05$

0.023008192

End of Forecast 
Summary:

Display Range is from 0 to $0.00035 \mathrm{ft}$

Entire Range is from 0.00000007037165064 to $0.011161343911771492 \mathrm{At}$ After 13,500 Trials, the Std. Error of the Mean is 0.000001128213047942

Statistics:

Trials

Volue

Mean

13500

Median (approx.)

$1.88364 \mathrm{E}-06$

Mode (approx.)

$1.86766 \mathrm{E}-05$

Standard Deviation

5.58767E-05

Variance

0.000131087

Skewness

$1.71837 E-08$

80.42672349

Kurtosis

Coeff. of Variability

6562.759049

Range Minimum

69.59211009

7.03717E-08

Range Maximum

0.011161344

Range Width

0.011161274

Mean Std. Error

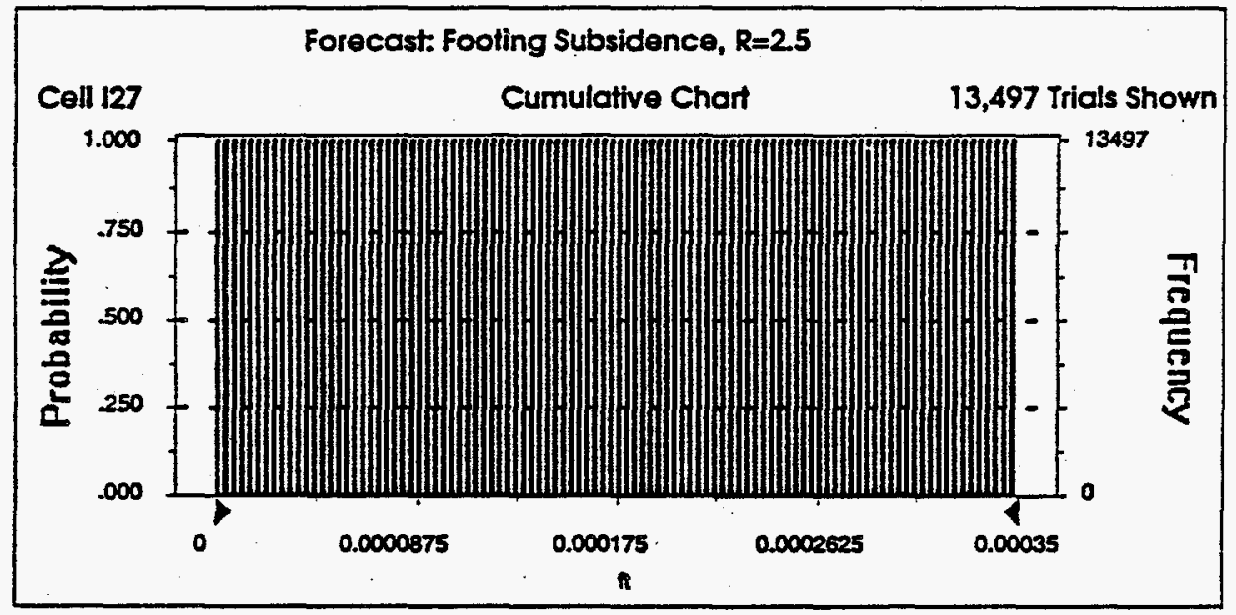


Forecast: Footing Subsidence, $R=2.5$ (cont'd)

Cell: 127

Percentiles:

\begin{tabular}{r} 
Percentile \\
\hline $0 \%$ \\
$10 \%$ \\
$25 \%$ \\
$50 \%$ \\
$75 \%$ \\
$90 \%$ \\
$100 \%$
\end{tabular}

It(aporox.)

7.03717E-08

3.79162E-06

9.3735E-06

1.86766E-05

2.79798E-05

3.35616E-05

0.011161344

End of Forecast 
Forecast: Factor of Safety, Radius $=5 \mathrm{ft}$

Summary:

Display Range is from 0.05 to 0.28

Entire Range is from 0.05 to 0.27

After 24,500 Trials, the Std. Error of the Mean is 0.00

$\begin{array}{lr}\text { Statistics: } & \text { Value } \\ \text { Trials } & 24500 \\ \text { Mean } & 0.15 \\ \text { Median (approx.) } & 0.15 \\ \text { Mode (approx.) } & 0.13 \\ \text { Standard Deviation } & 0.04 \\ \text { Variance } & 0.00 \\ \text { Skewness } & 0.24 \\ \text { Kurtosis } & 2.40 \\ \text { Coeff. of Variability } & 0.30 \\ \text { Range Minimum } & 0.05 \\ \text { Range Maximum } & 0.27 \\ \text { Range Width } & 0.22 \\ \text { Mean Std. Error } & 0.00\end{array}$

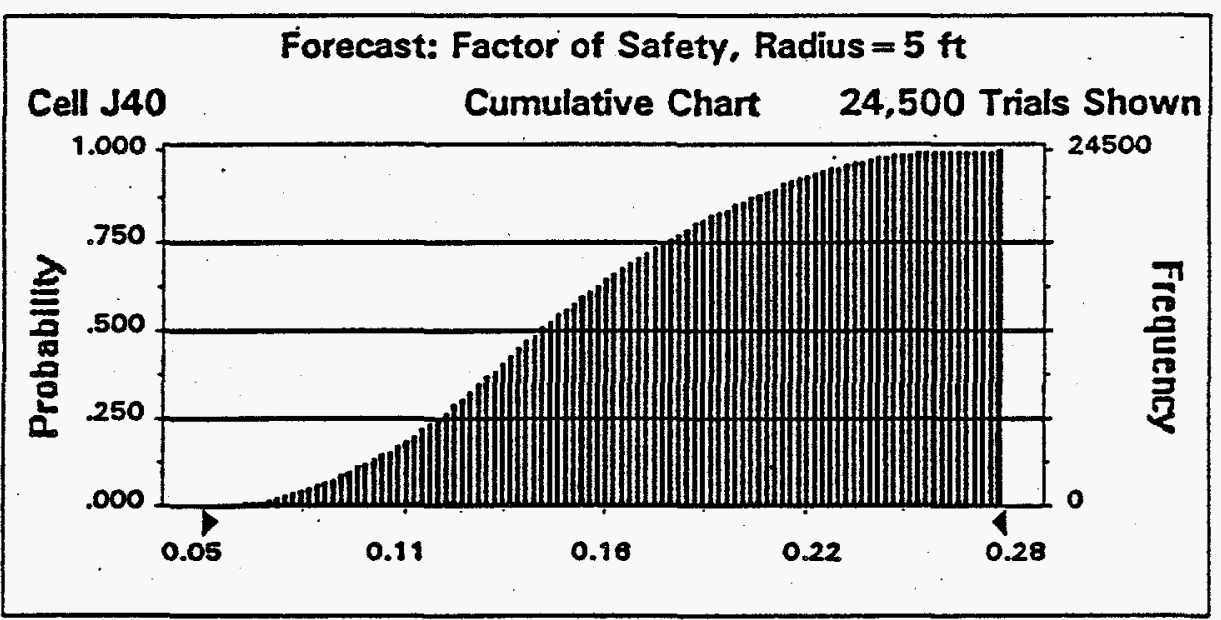


Forecast: Factor of Safety, Radius $=5 \mathrm{ft}$ (cont'd)

Percentiles:

\begin{tabular}{rr} 
Percentile & Value (approx.) \\
\hline $0 \%$ & 0.05 \\
$10 \%$ & 0.09 \\
$25 \%$ & 0.12 \\
$50 \%$ & 0.15 \\
$75 \%$ & 0.18 \\
$90 \%$ & 0.21 \\
$100 \%$ & 0.27
\end{tabular}

End of Forecast 
Summary:

Display Range is from 5.00 to 27.50

Entire Range is from 5.19 to 27.97

After 24,500 Trials, the Std. Error of the Mean is 0.03

$\begin{array}{lr}\text { Statistics: } & \text { Value } \\ \text { Trials } & 24500 \\ \text { Mean } & 14.90 \\ \text { Median (approx.) } & 14.52 \\ \text { Mode (approx.) } & 13.73 \\ \text { Standard Deviation } & 4.36 \\ \text { Variance } & 19.04 \\ \text { Skewness } & 0.26 \\ \text { Kurtosis } & 2.45 \\ \text { Coeff. of Variability } & 0.29 \\ \text { Range Minimum } & 5.19 \\ \text { Range Maximum } & 27.97 \\ \text { Range Width } & 22.78 \\ \text { Mean Std. Error } & 0.03\end{array}$

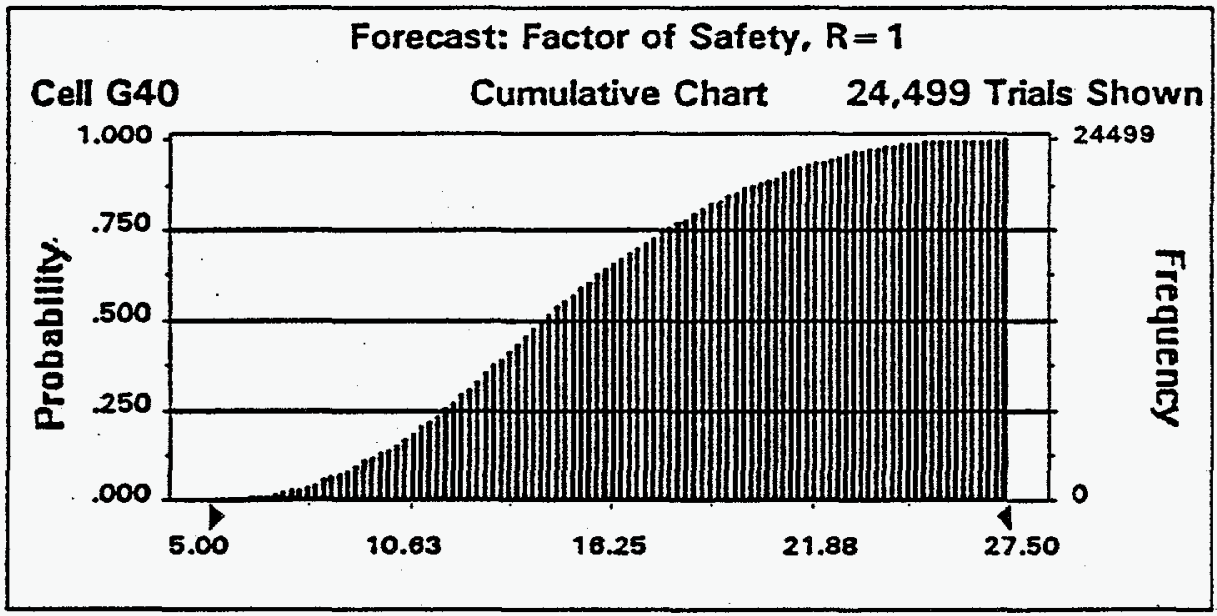


Forecast: Factor of Safety, $R=1$ (cont'd)

\section{Percentiles:}

$$
\begin{array}{r}
\text { Percentile } \\
\hline 0 \% \\
10 \% \\
25 \% \\
50 \% \\
75 \% \\
90 \% \\
100 \%
\end{array}
$$

Value (approx.)

5.19

9.30

11.69

14.52

18.00

21.05

27.97

End of Forecast 
Forecast: Factor of Safety, $\mathbf{R = 2 . 5}$

Cell: $H 40$

Summary:

Display Range is from 0.25 to 2.00

Entire Range is from 0.34 to 1.83

After 24,500 Trials, the Std. Error of the Mean is 0.00

$\begin{array}{lr}\text { Statistics: } & \text { Value } \\ \text { Trials } & 24500 \\ \text { Mean } & 1.00 \\ \text { Median (approx.) } & 0.97 \\ \text { Mode (approx.) } & 0.90 \\ \text { Standard Deviation } & 0.29 \\ \text { Variance } & 0.08 \\ \text { Skewness } & 0.25 \\ \text { Kurtosis } & 2.43 \\ \text { Coeff. of Variability } & 0.29 \\ \text { Range Minimum } & 0.34 \\ \text { Range Maximum } & 1.83 \\ \text { Range Width } & 1.48 \\ \text { Mean Std. Error } & 0.00\end{array}$

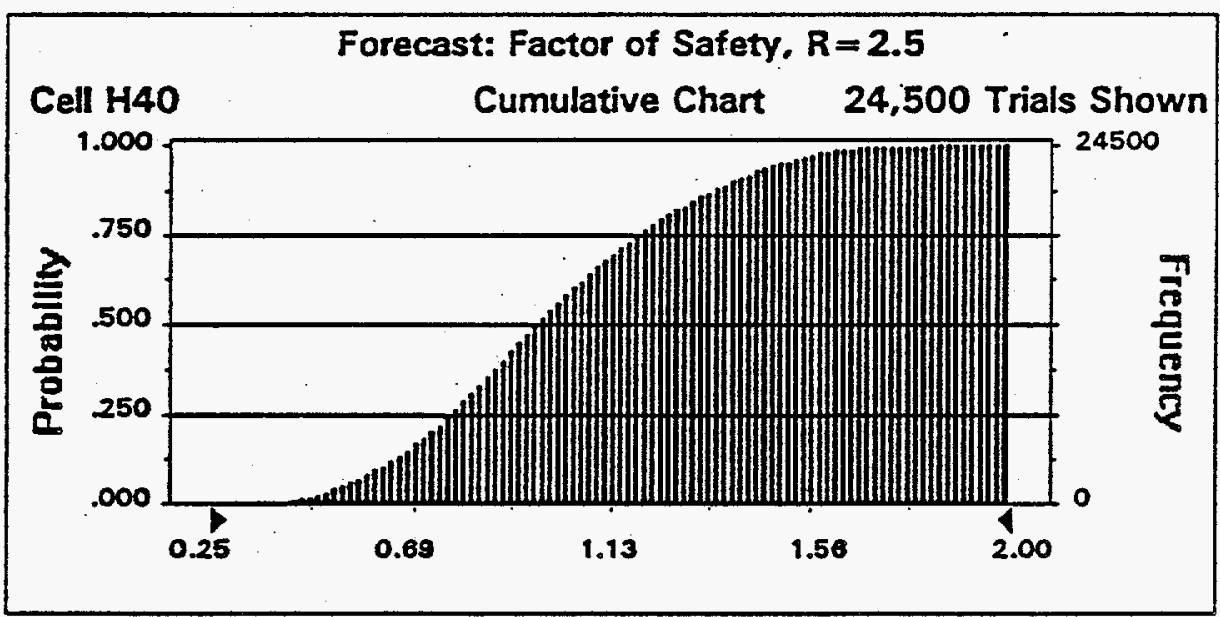


Forecast: Factor of Safety, $R=2.5$ (cont'd)

Percentiles:

\begin{tabular}{r} 
Percentile \\
\hline $0 \%$ \\
$10 \%$ \\
$25 \%$ \\
$50 \%$ \\
$75 \%$ \\
$90 \%$ \\
$100 \%$
\end{tabular}

Value (approx.)

0.34

0.62

0.78

0.97

1.20

1.40

1.83

End of Forecast 
Summary:

Display Range is from 0.05 to 0.50

Entire Range is from 0.09 to 0.49

After 24,500 Trials, the Std. Error of the Mean is 0.00

Statistics:

Value

Trials

24500

Mean

0.27

Median (approx.)

0.26

Mode (approx.)

0.25

Standard Deviation

0.08

Variance

0.01

Skewness

0.25

Kurtosis

2.44

Coeff. of Variability

0.29

Range Minimum

0.09

Range Maximum

0.49

Range Width

0.40

Mean Std. Error

0.00

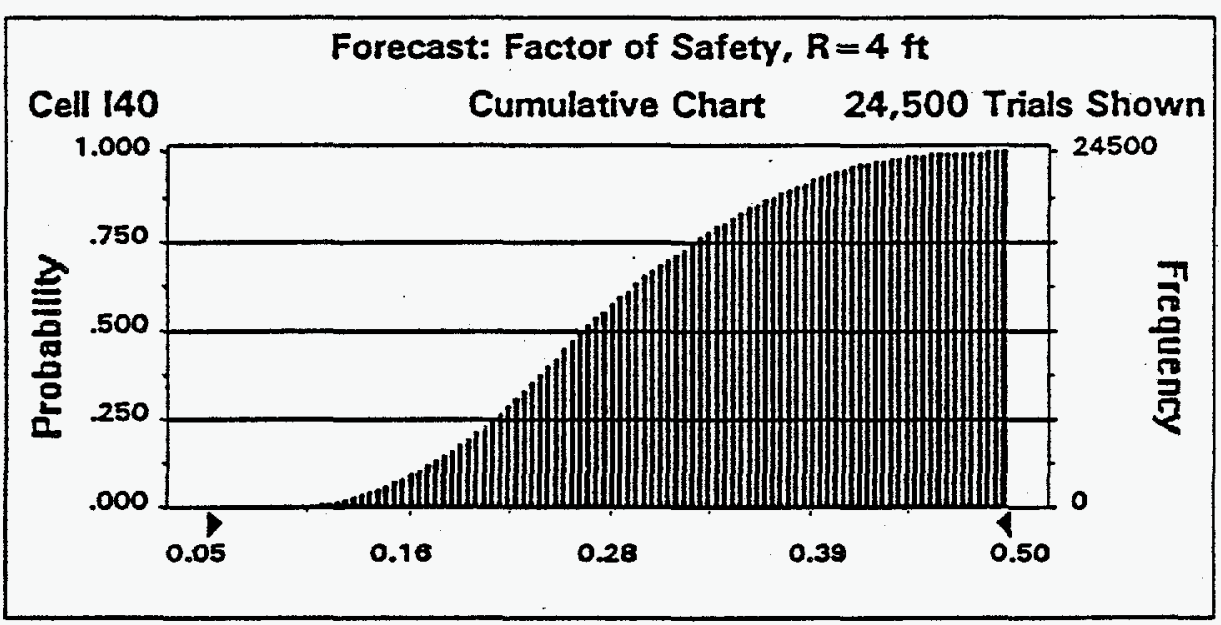


Forecast: Factor of Safety, $R=4 \mathrm{ft}$ (cont'd)

Percentiles:

\begin{tabular}{r} 
Percentile \\
\hline $0 \%$ \\
$10 \%$ \\
$25 \%$ \\
$50 \%$ \\
$75 \%$ \\
$90 \%$ \\
$100 \%$
\end{tabular}

Value (approx.)

0.09

0.17

0.21

0.26

0.33

0.38

0.49

End of Forecast

B.64 
Summary:

Display Range is from 0.05 to 0.28

Entire Range is from 0.05 to 0.27

After 24,500 Trials, the Std. Error of the Mean is 0.00

Statistics:

Value

Trials

24500

Mean

0.15

Median (approx.)

0.15

Mode (approx.)

0.13

Standard Deviation

0.04

Variance

0.00

Skewness

0.24

Kurtosis

2.40

Coeff. of Variability

0.30

Range Minimum

0.05

Range Maximum

0.27

Range Width

0.22

Mean Std. Error

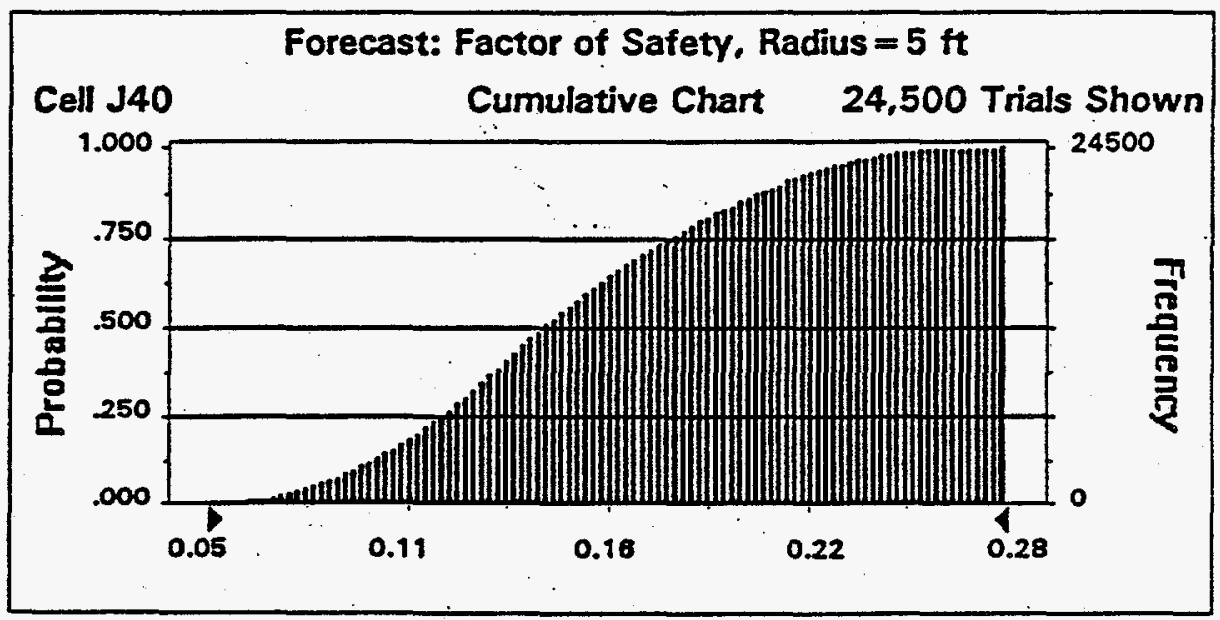

B. 65 
Forecast: Factor of Safety, Radius $=5 \mathrm{ft}$ (cont'd)

Percentiles:

\begin{tabular}{rr} 
Percentile & Value (approx.) \\
\hline $0 \%$ & 0.05 \\
$5 \%$ & 0.08 \\
$25 \%$ & 0.12 \\
$50 \%$ & 0.15 \\
$75 \%$ & 0.18 \\
$95 \%$ & 0.23 \\
$100 \%$ & 0.27
\end{tabular}

End of Forecast

B.66 
Forecast: Factor of Safety, $R=1$

Summary:

Display Range is from 5.00 to 27.50

Entire Range is from 5.19 to 27.97

After 24,500 Trials, the Std. Error of the Mean is 0.03

$\begin{array}{lr}\text { Statistics: } & \text { Value } \\ \text { Trials. } & 24500 \\ \text { Mean } & 14.90 \\ \text { Median (approx.) } & 14.52 \\ \text { Mode (approx.) } & 13.73 \\ \text { Standard Deviation } & 4.36 \\ \text { Variance } & 19.04 \\ \text { Skewness } & 0.26 \\ \text { Kurtosis } & 2.45 \\ \text { Coeff. of Variability } & 0.29 \\ \text { Range Minimum } & 5.19 \\ \text { Range Maximum } & 27.97 \\ \text { Range Width } & 22.78 \\ \text { Mean Std. Error } & 0.03\end{array}$

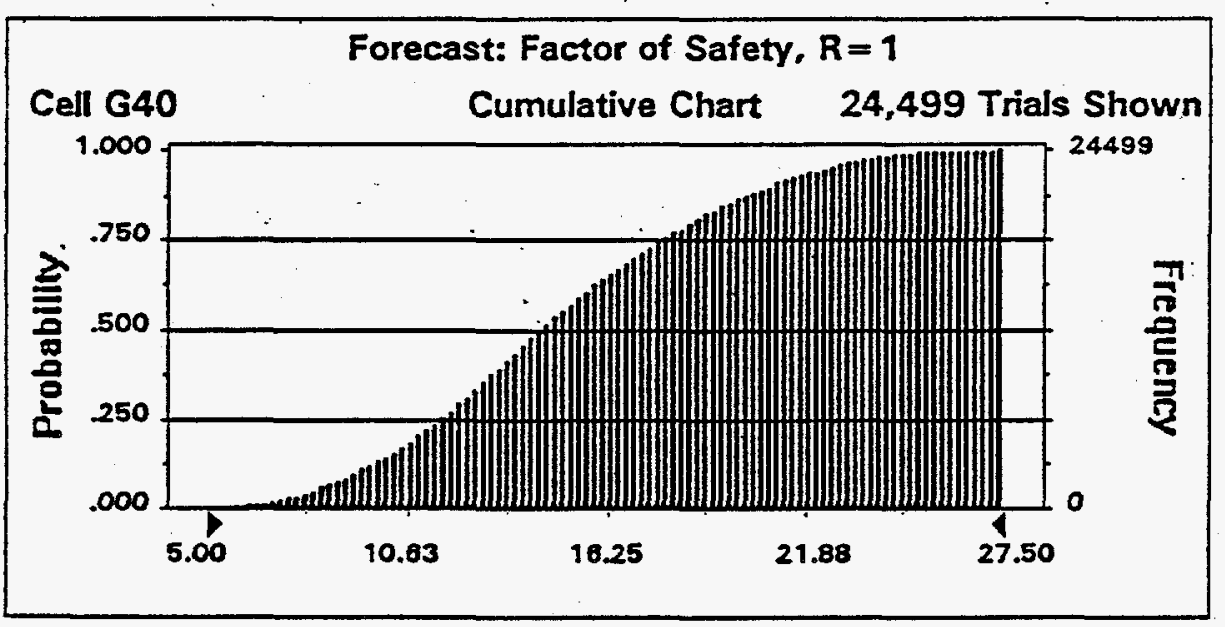

B.67 
Forecast: Factor of Safety, $R=1$ (cont'd)

Percentiles:

\begin{tabular}{r} 
Percentile \\
\hline $0 \%$ \\
$5 \%$ \\
$25 \%$ \\
$50 \%$ \\
$75 \%$ \\
$95 \%$ \\
$100 \%$
\end{tabular}

Value (approx.)

5.19

8.15

11.69

14.52

18.00

22.63

27.97

End of Forecast 
Summary:

Display Range is from 0.25 to 2.00

Entire Range is from 0.34 to 1.83

After 24,500 Trials, the Std. Error of the Mean is 0.00

$\begin{array}{lr}\text { Statistics: } & \text { Value } \\ \text { Trials } & 24500 \\ \text { Mean } & 1.00 \\ \text { Median (approx.) } & 0.97 \\ \text { Mode (approx.) } & 0.90 \\ \text { Standard Deviation } & 0.29 \\ \text { Variance } & 0.08 \\ \text { Skewness } & 0.25 \\ \text { Kurtosis } & 2.43 \\ \text { Coeff. of Variability } & 0.29 \\ \text { Range Minimum } & 0.34 \\ \text { Range Maximum } & 1.83 \\ \text { Range Width } & 1.48 \\ \text { Mean Std. Error } & 0.00\end{array}$

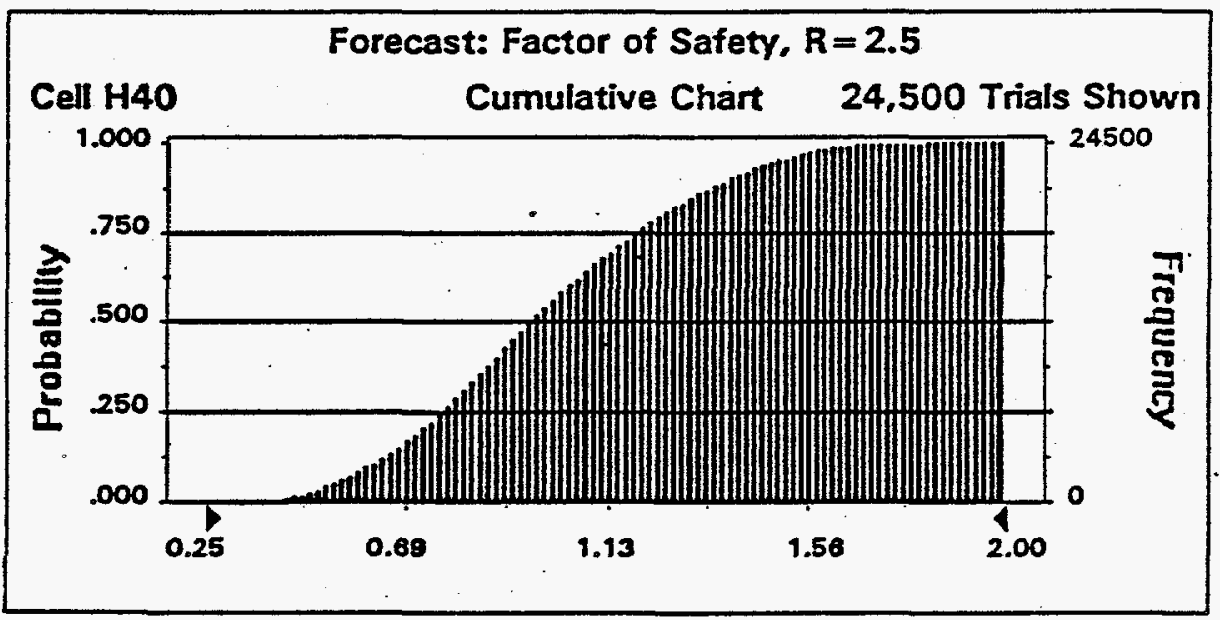


Forecast: Factor of Safety, $R=2.5$ (cont'd)

Percentiles:

\begin{tabular}{rr} 
Percentile & Value lapprox.l \\
\hline $0 \%$ & 0.34 \\
$5 \%$ & 0.54 \\
$25 \%$ & 0.78 \\
$50 \%$ & 0.97 \\
$75 \%$ & 1.20 \\
$95 \%$ & 1.51 \\
$100 \%$ & 1.83
\end{tabular}

End of Forecast

B.70 
Summary:

Display Range is from 0.05 to 0.50

Entire Range is from 0.09 to 0.49

After 24,500 Trials, the Std. Error of the Mean is 0.00

Statistics:

Value

Trials

24500

Mean

0.27

Median (approx.)

0.26

Mode (approx.)

0.25

Standard Deviation

0.08

Variance

0.01

Skewness

0.25

Kurtosis

2.44

Coeff. of Variability

0.29

Range Minimum

0.09

Range Maximum

0.49

Range Width

0.40

Mean Std. Error

0.00

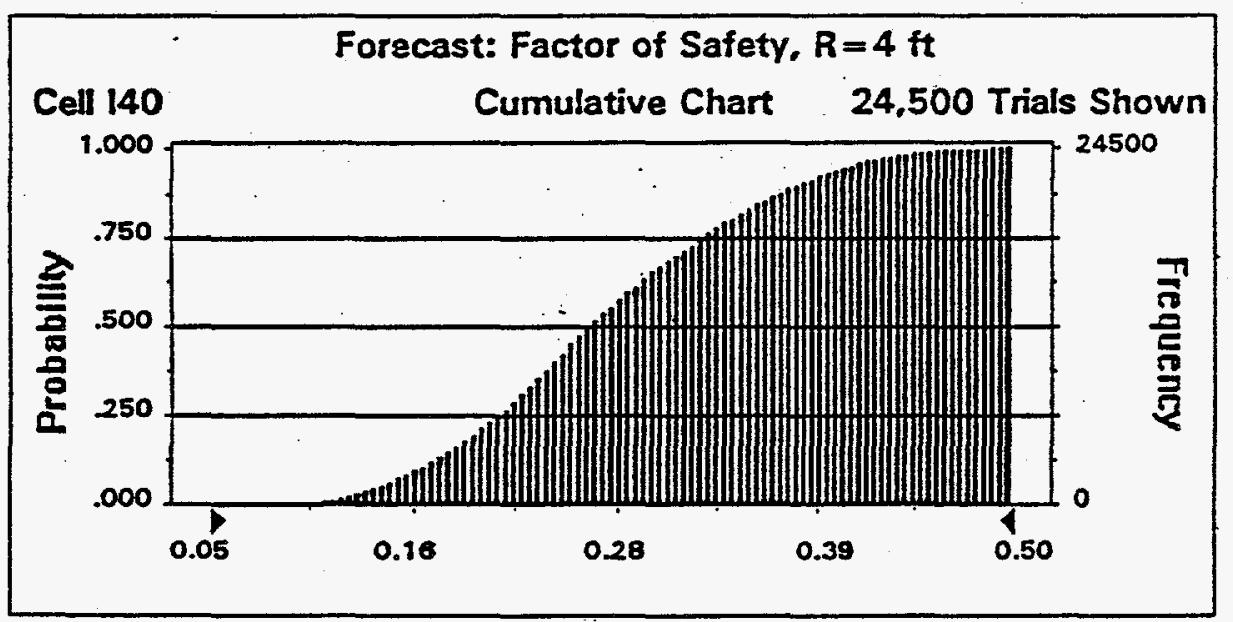


Forecast: Factor of Safety, $R=4 \mathrm{ft}$ (cont'd)

Percentiles:

\begin{tabular}{r} 
Percentile \\
\hline $0 \%$ \\
$5 \%$ \\
$25 \%$ \\
$50 \%$ \\
$75 \%$ \\
$95 \%$ \\
$100 \%$
\end{tabular}

Value (aporox.)

0.09

0.15

0.21

0.26

0.33

0.41

0.49

End of Forecast

B.72 


\section{Distribution}

No. of

Copies

Offsite

2 DOE/Office of Scientific and Technical Information

Onsite

2 Bechtel Hanford Incorporated M. C. Hagood, H6-02

K. J. Koegler, H6-02
No. of

Copies

26 Pacific Northwest Laboratory
A. H. Ignatov, P7-18
J. Luey, P7-34 (15)
T. L. Page, K1-31
M. E. Peterson, P7-41
D. K. Seiler, P7-34
S. C. Slate, K1-25
Publishing Coordination
Technical Report Files (5) 